Historic, Archive Document

Do not assume content reflects current scientific knowledge, policies, or practices. 


\section{A SHORT GUIDE}

TO THE BEST VARIETIES OF EVERGREENS, SHADE TREES, SHRUBS, FORESTRY SEEDLINGS, TRANSPLANTS, ETC., WITH SPECIAL QUANTITY PRICES FOR THE YEAR OF 1932

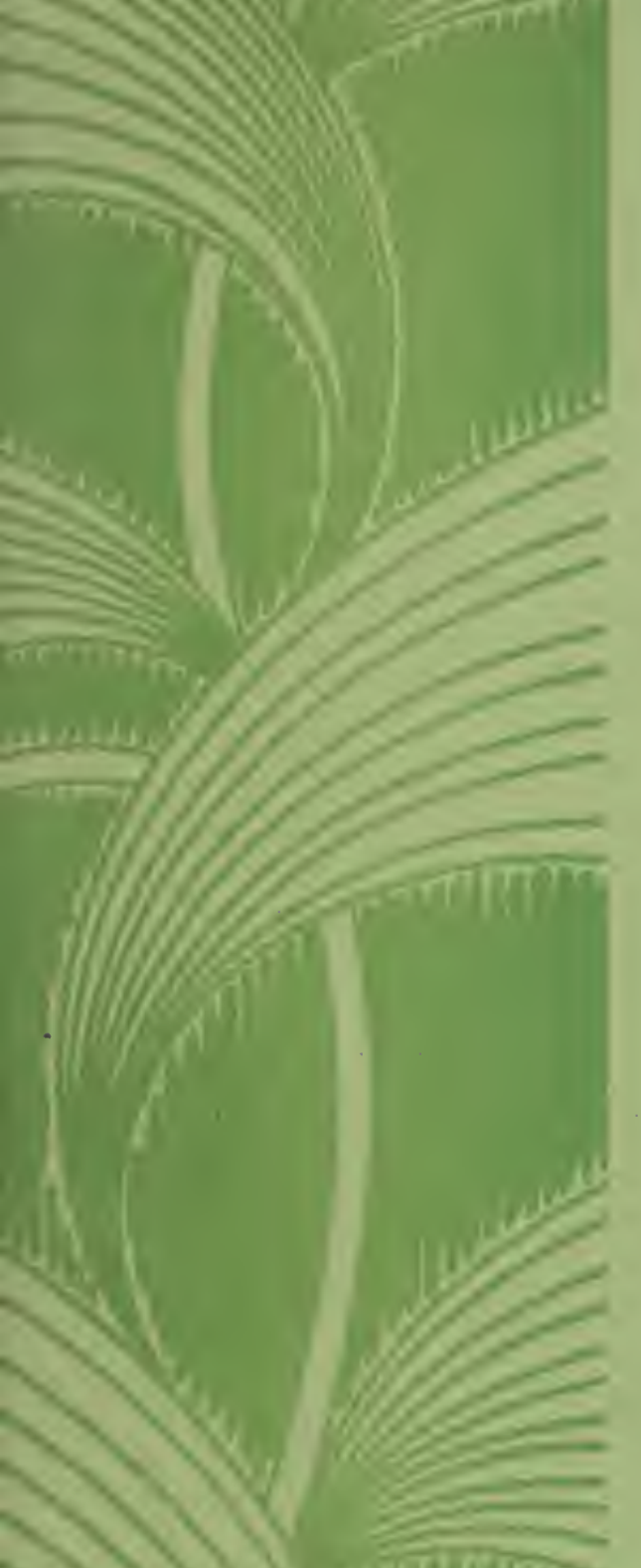
TITYPRICES FOR THE YEAR OF 1932

\section{Kelsey Nursery Service 50 CHURCH STREET, NEW YORK CITY.}


1. Kelsey Nursery Stock is grown where it grows best, always with due regard to shipping advantages. On thousands of acres of nursery land operated by the more than seventy growers, is grown a selection of hardy stock not equalled by any one or more nurseries. Each grower is of recognized standing and competency. All stock furnished is the property of this Company, and we are amply responsible therefor: And from our long and successful experience have exceptional facilities for prompt and efficient service.

2. We furnish our stock at the lowest prices made possible by mass production. Prices of nursery stock vary greatly. One nursery grows stock on land worth, say, $\$ 4,000$ or $\$ 5,000$ per acre. The stock is no better than that grown at a nearby nursery where land is worth perhaps $\$ 400.00$ per acre. Nature has no partiality in this respect. We are, therefore, enabled to sell excellent stock, like the department stores, in great variety at the very lowest prices.

3. We are an entirely responsible source of supply. Established in 1878, we still have among our customers many who have been patrons for forty years or more. In all our dealings we are always willing to make things right on any errors or just causes for complaint.

4. Our Guarantee Stock to be in good condition when furnished. We will, however, replace any and all losses at half price.

5. Scarce and rare varieties: Why look through a dozen nursery catalogues for them? Send us your list and we will quote promptly. This Short Guide, though very complete and filled with reliable information, is necessarily confined to standard varieties, but with our facilities we can furnish almost any variety or size grown in the United States.

6. The policy of this Company is to cultivate and keep good will by careful and prompt service.

PRICES-net, packing at cost. Five will be supplied at the 10 rate, 50 at the 100 , and 250 at the 1000 rate.

Claims for errors or shortage to be made within ten days.

\section{CONTENTS}

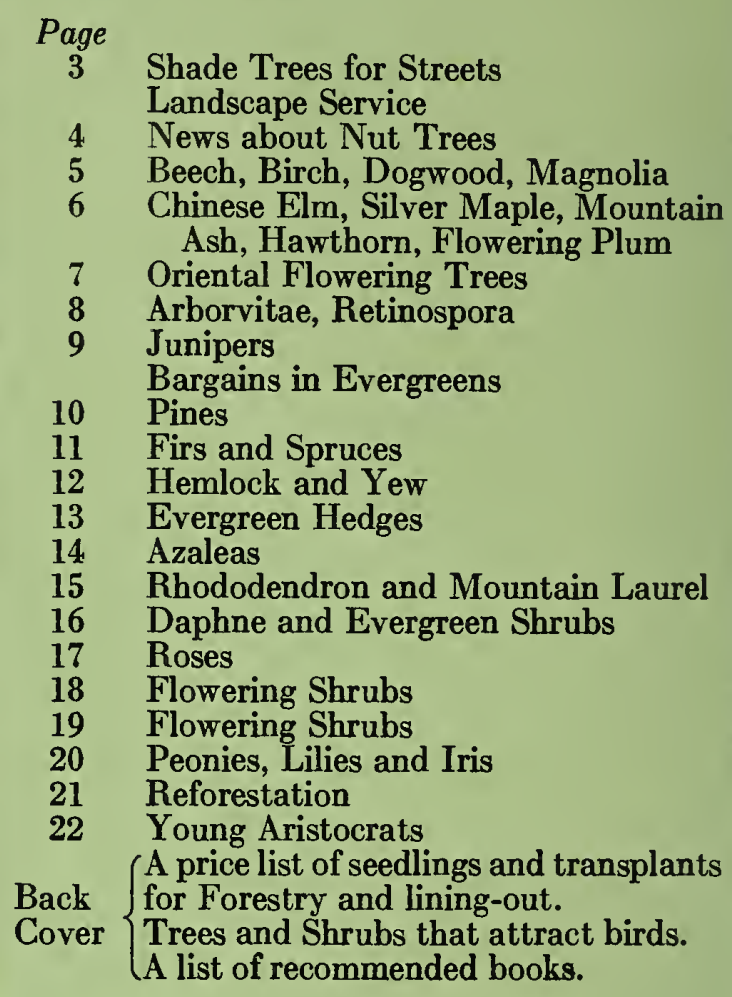

3 Shade Trees for Streets

Landscape Service

4. News about Nut Trees

5 Beech, Birch, Dogwood, Magnolia

6 Chinese Elm, Silver Maple, Mountain

Ash, Hawthorn, Flowering Plum

7 Oriental Flowering Trees

8 Arborvitae, Retinospora

9 Junipers

Bargains in Evergreens

10 Pines

11 Firs and Spruces

12 Hemlock and Yew

13 Evergreen Hedges

14. Azaleas

15 Rhododendron and Mountain Laurel

16 Daphne and Evergreen Shrubs

17 Roses

18 Flowering Shrubs

19 Flowering Shrubs

20 Peonies, Lilies and Iris

21 Reforestation

22 Young Aristocrats

A price list of seedlings and transplants

Back for Forestry and lining-out.

Cover Trees and Shrubs that attract birds. A list of recommended books.

\section{KEY TO NOTES}

The information and cultural notes in this Guide have been carefully prepared and are trustworthy. The letters following the name of each variety throughout this Price-List refer to the table published herewith. The figures following each name indicate ultimate height at maturity.
A-Profuse bloomer.
B-Flowers very large.
C-Good for cut flowers.
D-Likes a light warm soil.
E-Any good soil.
F-Likes moist ground.
$\mathrm{G}$--Slow growing.
H-Rapid growing.
I-Requires protection first year.
J-Requires sheltered position.
$\mathrm{K}$-Very hardy.

\section{F. W. KELSEY NURSERY COMPANY}




\section{Shade Trees for Street Planting}

G OOD shade trees in the proper sizes have been scarce and dear, owing to the George Washington Anniversary. This season we offer a good supply of fine well transplanted trees in the best varieties. The prices represent distinct bargains. In most cases we can make shipment either from the East or the Middle West, representing a saving on freight. However, in large quantity shipments, it is advisable to write for quotation which will be cheerfully furnished. Not in years have we offered such an assortment of strictly first grade trees at such low prices.

\section{ELM (UImus)}

U. Americana (Amcrican Elın) (100)

1 to $1 \frac{1}{4}$ inches caliper... \$ 95.00 $11 / 4$ to $11 / 2$ inches. 100.00 $1 \frac{1}{2}$ to $13 / 4$ inches.... . . 160.00 $13 / 4$ to 2 inches..... $\quad 200.00$ 2 to $21 / 2$ inches....... 300.00 $21 / 2$ to 3 inches....... 1.50 .00

(1000)

$\$ 700.00$ 900.00 1200.00 1800.00 2700.00

U. glabra (Scoleh or Wyoh Elm)

6 to 8 feet $\quad \ldots \quad 100.00$

8 to 10 feet, 1 to $11 / 4$ inches 11.0 .00

$11 / 4$ to $1 \frac{1}{2}$ inches..... 190.00

$11 / 2$ to $13 / 4$ inches. . . . . 250.00

U. Campestris (English Elm)

One of the best trees for street planting in America. Does well in City conditions. I Iighly recommented by the kate Dr. Wilson.

6 to 8 fret........\$\$ \$ $\$ 90.00 \$ 800.00$

8 to 10 feet ........ $150.00 \quad 1200.00$

\section{OAK (Quercus)}

Q. palustris (Pin Oak)

6 to 8 feet. . . . . $\$ \$ \$ 250.00$

8 to 10 feet, 1 to $1 \frac{1}{4}$ in. . $\quad 320.00$

Q. rubra (Rod Oak)

6 to 8 feet.

8 to 10 feet

16.5. 00

225.00

$11 / 4$ to $1 \frac{1}{2}$ inches.

$1 \frac{1}{2}$ to $13 / 4$ inches

275.00

320.00

$13 / 4$ to 2 inches. .

1.5 .00

\section{Oriental Plane ... Finest Shade Tree for Streets}

This charming species is one of the few trees really adapted to succeed under city conditions. Poor air-even smoke and gases-and difficult soils seem to affect the Plane Tree very little. This fact is important by itself, but in addition the Plane is a beautiful specimen, with a neat dense head and charming shape even while young. The two-toned bark and handsome dark green leaves are known and prized wherever streets are planted with trees. We have a block of 2000 of these trees running from 11/4 to 2 inches in caliper, twice transplanted, well branched and straight. These we are offering at almost give-away prices for the quality:
$11 / 4$ to $1 \frac{1}{2}$ inches
$\$ 132.50$ per 100
$11 / 2$ to $13 / 4$ inches
175.00 per 100
$13 / 4$ to: inclies
2 to $21 / 2$ inclies
$\$ 225.00$ per 100
350.00 per 100

And special prices quoted on lots of 200 or nore)

Writa us your needs and let us quote you.

\section{MAPLE (Acer)}

A. Pla lauoides (Norway Maple)

Fine trees. Ready for street planting in the larger sizes.

6 to 8 feet.

8 to 10 feet

$11 / 4$ to $1 \frac{1}{2}$ inches

$11 / 2$ to $13 / 4$ inches.

$13 / 4$ to 2 inches.

2 to $21 / 2$ inches

$21 / 2$ to 3 inches.

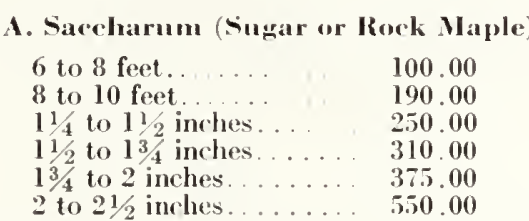
$(100)$
$\$ 150.00$ 225.00 $250.00 \$ 2100.00$ $300.00 \quad 2900.00$ $130.00-1000.00$ 1000.00 6000.00
I.INI)EN (Tilia)

I. vulgaris (European Linden)

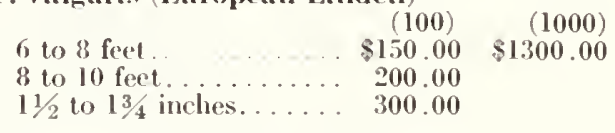

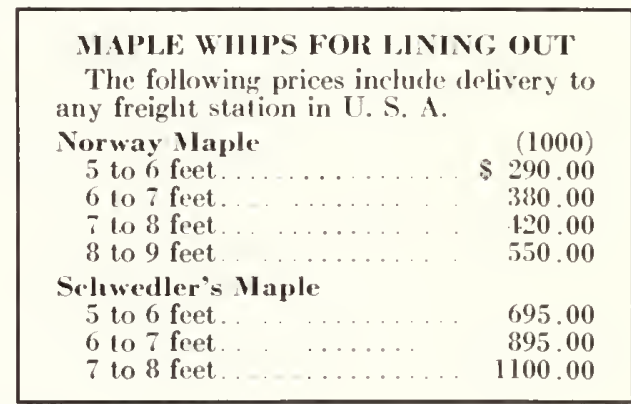

Write for quotations on your requirements.

\section{And now-Kelsey Landscape Service}

W

TE are in a position to solicit orders and inquiries for moving large trees, furnishing specimens, laying out grounds, with incident construction and engineering. We are not landscape architects. We offer to lo the work-not to plan it. Rare and unusual varieties and special sizes of material-stone-work-grading and top-soil-lawn-making-a complete landscape

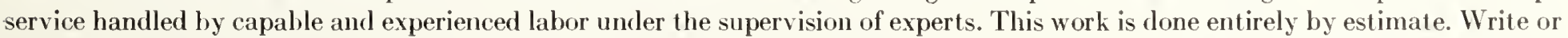

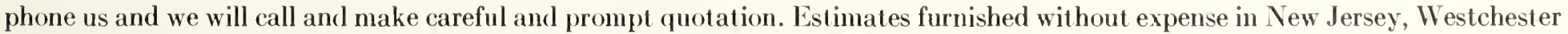

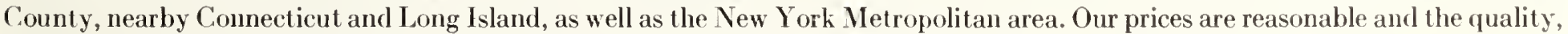
without exception, up to the most rigid standards of current landscape practice. References gladly given. 


\section{Here's Real News about Nut Trees}

T last we are able to offer our customers an opportunity to buy and enjoy the remarkable new hybrid nut trees. Hybridizers and experimenters have been working on this problem for years. Hardy types of both English Walnuts and Pecans are now

available for the North. Delicious Black Walnuts with easily opened shells . . Hybrid Hickories with haunting flavor previously unknown even to epicures . . most amazing of all, these varieties will bear nuts as early as the third or fourth year after planting. The varieties we offer here have been thoroughly tested for some years. They are now growing as far north as Canada. And not only for the nuts... most of these trees also make beautiful specimens and excellent shade trees.

\section{BLACK WALNUTS (Juglans nigra)}

Torth America has more and fincr native nut trees than any other continent. This Black Walnut is naturally one of our nost stately and beautiful native trees and produces one of the finest nuts in the world. It is hardy in Canarla and in Floridla, growing well in any fertile well drained soil. But the grafted sorts grow faster and the nuts thinner slielled, with plump meat that comes out readily. The flavor is unique and is not lost in cooking (this can be said of no other nut). The new grafted varicties bcal their first nuts sometimes in the second year after planting and commonly in the third to fifth year if the tree is properly fertilized. There are sevcral varieties, but the two below seem to be the best.

Stabler has the thinnest shell. The meat falls out easily in two halves and is of a rich mellow flavor. The tree makes a fine spreading specimen with unusually ornamental form and foliage.

Thomas is a really rapid-growing tree, hardy and easy to grow. The meat is attractive and tasty, but does not crack as easily as the Stabler.

\section{ENGLISH WALNUTS (Juglans regia)}

If these be grafted on Black Walnut roots, the wood ripens much sooner than otherwise. Hence, such trecs can stand much colder weather and are now doing well in extensive plantings in New England and even Michigan. The grafted varieties are not only hardy, but the nut is tasty and thinshellcd, of large size.

Wiltz-Mayette is perhaps the best variety for all purposes. The shell can be cracked in the fingers. The meat is plump, white and not in the least bitter. It is a reliable bearer. The English Walnut requires a lime soil and wherc this is not natural, it is imperative that lime or erushed limestone be plentifully added to the planting soil. The first crop may he expected in three or four years. The nuts will keep prime for two years.

\section{NU'T 'TREES FOR FORESTRY}

We offer seedling nut trees as well. Not so nuch for the nuts, since these will be of undeterminable value, but as valuahle timber.

Hickory - Very valuable special purpose wood. Walnut-A slow crop, but very profitable.

Beceh-A valuahle special purpose wood.

Oak-Always in demand.

Black Walnut (Juglans niwra)

12 to 18 inches.......... \$1.50 $\$ 30.00$

Butternut (J. cinerea)

2 to 3 feet........... $6.00 \quad 50,00$

American Beech (Fagus)

12 to 18 inches.

$3.00 \quad 15.00$

NUT FOREST OFFER No.

Ten each of all the above varieties -60 treps-nursery-grown seedlings, 12 to 18 inches high, packed for shipment and

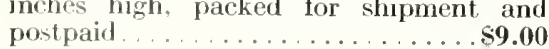

Thomas and Stabler

\section{PRICES OF GRAFTED NU'T 'TREES}

Blaek Walmut

4 to 6 feet

6 to 8 feet

8 to 10 feet

English Walmut

Wiltz-Mayette

4 to 6 feet.

Hybrid Hiekories

McAllister

4 to 6 fcet

6 to 8 feet.

Burlington (Marquardt)

4 to 6 feet

6 to 8 feet

Northern Peeans

Busseron and Butterick

6 to 8 feet $\ldots \ldots \ldots \ldots \ldots$
8 to 10 feet $\ldots \ldots \ldots \ldots \ldots$
10.00

Can furnish specimens guaranteed to have borne nuts last year at $50 \%$ extra)

Above prices for straight stock. We will prune properly before shipping. Nut trees need this. Some crooked trees available at $15 \%$ discount while they last. They bear just as well and will straighten in time.

\section{HARDY NORTHERN PECANS (Carya ovaliformis)}

The commercial pecan varieties originated in the South, but the ones we offer come from Indiana and Illinois originally. Some of the varieties are hardy in Canada and will bear in Southern New England and the lower Lake region. The quality of the nuts in these varieties is in every way the equal of commercial Pecans. They will bear in three to five years.

Busseron and Butteriek are the oldest and best varieties. The diflerences in growth and quality of the nut are slight. It is very advisable to plant one of each kind so that they will cross fertilize.

Consider the value of nut trees for reforestation of waste land. They grow on soil too poor for evergreens. Although, aside from the pleasure and value of yearly crops of nuts, the wood is extrenely valuable as timber-more so than any other class of tree that can be grown Mass methods of produetion allow prices which make immediate forest planting practicable now.

Pin Oak (Quercus pahnstris)

12 to 18 inches.

(100) (1000)

Shagbark Hiekory (H. ovata)

6 to 12 inches........... $7.00 \quad 60.00$

IIazlenut (Corylus)

12 to 18 inches.

$4.00 \quad 25.00$

\section{YU'T FORES'T OFFER No. 2}

Three of all the above- 18 trees-2 to 3 feet high. packed for shipment and postpaid

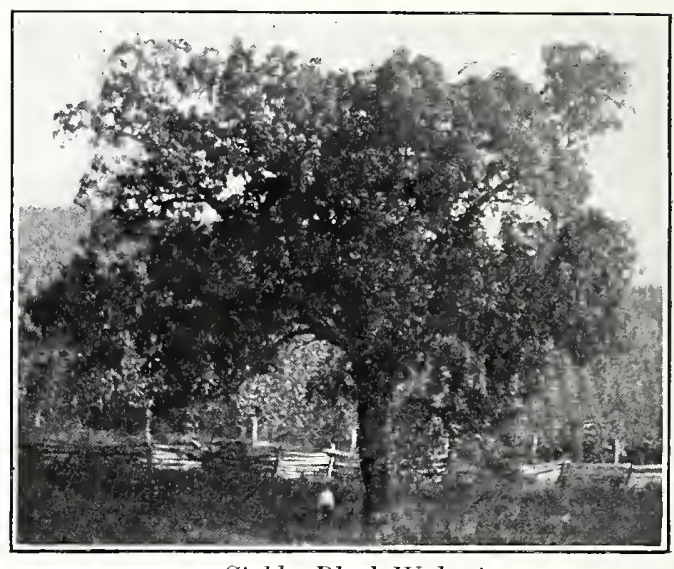

Stabler Black Walnut

\section{HYBRID HICKORIES}

The Shagbark IIickory is a eharming tree but the wild nuts are hard to crack and come into bearing very slowly. But these excellent hybrids inherit all the good points and eliminate the bad - for the nut has a thin, soft shell and a flavor which inust be experienced to be believed. The best varieties are the two below-both absolutely hardy and good bearers, starting four to five years after planting. They both grow rapidly when fertilized.

MeAllister is a unique tree. Most of the hybrids resemble the pecan in flavor as well as in shape. The McAllister is nearly as thin shelled as any pecan, but its flavor is that of the delicious wild shell-bark hickory. The nut is over twoinches in length and is larger than any southern pecan. The kernel is plump and full, the largest in the IIicoria genus. It makes a wide spreading specinen with foliage resembling the pecan-a bcautiful tree.

Burlington (also called Marquardt) resembles the pecan as to the nut. The tree is very easily grown, a rapid grower and extremely hardy. Does well in Minnesota.

\section{BLIGHT RESISTAN'T CHESTNUTS}

The Chinese Chestnut (Castanea molissima) is larger than the American and of fine flavor and sweet. It is so inured to the Chestnut Blight (which also came from China and very destructive of our native species) that it may be planted with safety. The tree is not large-seldom growing above 40 feet. It is absolutely hardy in Northcrn United States . . . a beautiful tree producing sweet nuts at an early age. Now that the American Sweet Chestnut cannot be recommended for many parts of the country, this species amply takes its place so far as nutproducing is concerned.

\begin{tabular}{|c|c|c|}
\hline \multicolumn{3}{|c|}{ Chinese Chestnut } \\
\hline Mollissima & & \\
\hline 3 to 4 feet & $\$ 1.50$ & $\$ 12.50$ \\
\hline 1 to 6 feet & 2.50 & 20.00 \\
\hline 6 to 8 feet. & 1.00 & $\ldots$ \\
\hline
\end{tabular}




\section{Here are Hurry Trees}

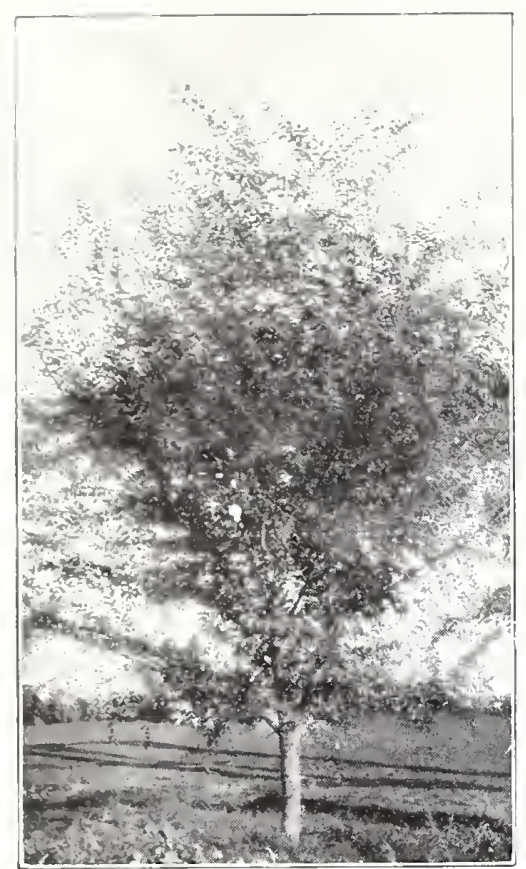

POPLARS (Populus)

We have many varieties to offer, but the recent State quarantines make it desirable that you write for our very low prices, depending on what State you are in. Please advise how nuany and what kinds you are interested in. These trees are extremely rapid in growth and very useful for many purposes.

\section{PURPLELEAVED PLUM (Prunus pissardi)}

Pictured below. EHK -8 to 10 feet. Striking purplish foliage which does not fade in Summer. Covered with pink flowers in May. I fine small specimen.

4 to 5 feet

(Each) $\$ 1.00$

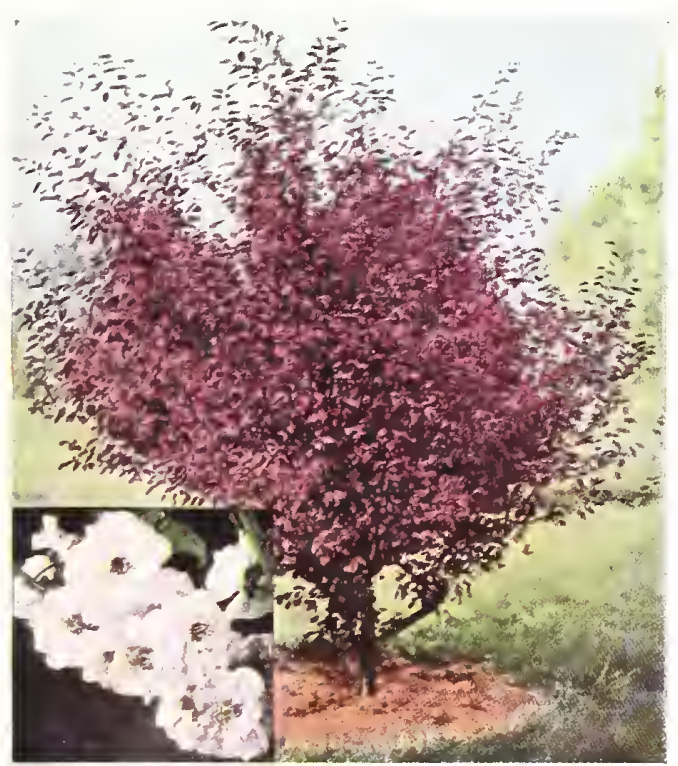

Purpleleared Plum

\section{THE CHINESE (OR SIBERIAN) ELM- ULMUS PUMILA}

$\mathrm{W}$ HERE screen or shade is wanted in a hurry - and yet permanent screen and pleasing shade-page the new Chinese Elm. Phenomenal tales of its speedy growth and hardiness are told and most of them strangely enough seem to be true. It has few troubles. The only one seems to be a distaste for heavy or poorly drained soils. It grows slowly on such land, and does best on sandy or dry situations. Each tree, upon planting, should be trimmed back. These trees offered below are grown for one season or more in New England and were raised from hardy North China Seed.

There is a distinct advantage in having trees of this species hardened off in the Eastern climate. They will take hold much more briskly and give less trouble. The tree is shapely and seems to be immune to nearly all the common diseases of trees. With the recent invasion of Dutch Elm disease this immunity is a distinct factor. The wood is firm and hard and quite tough. In Siberia where the Ulmus pumila is native, it is used for trimming and shearing for hedges and formal effects, for it is a bushy compact grower.

\begin{tabular}{|c|c|c|c|c|c|c|c|}
\hline & (Each) & (10) & $(100)$ & & (Each) & $(10)$ & $(100)$ \\
\hline & $\$ 1.75$ & $\$ 15.00$ & $\$ 135.00$ & $11 / 2$ to $13 / 4$ inch & $\ldots \$ 4.50$ & $\$ 42.50$ & $\$ 400.00$ \\
\hline & 3.00 & 27.50 & 260.00 & $1_{3}^{3}$ to 2 inches. & .5 .50 & 52.50 & 500.00 \\
\hline & 3.75 & 36.00 & 350.00 & $21 / 2$ to 3 inches & 7.50 & 70.00 & \\
\hline
\end{tabular}

\section{WILLOWS (Salix)}

These are rapid growing trees when their pale green leaves open. Best known are the Weeping Willows. There are several types, the Babylonica doing well near water and the Wisconsin in drier locations. We are not pricing these, due to State quarantines. Will gladly quote on your requirements upon request. They are very reasonable indeed in price, generally speaking.

\section{SILVER MAPLE (Acer dasycarpum)}

A fine native. Very fast growing and with heautiful green lcaves, silver on the under surface.

8 to 10 feet....... $\begin{array}{ccc}\text { (Each) } & (10) & (100) \\ \$ 1.50 & \$ 14.00 & \$ 50.00\end{array}$
10 to 12 feet $\ldots \ldots \ldots, \quad 2.25 \quad 20.00 \quad 65.00$

(Note extremely low quantity rates)

\section{HAWTHORN (Crataegus)}

The Ilawthorns are small, shrubby trees with beautiful glossy green foliage. Slowy and fragrant blooms are produced in the Spring and in the Fall they are very attractive with their brilliant foliage and ornamental fruit.

Paul's Scartet IIawthorn (C. oxycantha splendens)

Very double deep crimson flowers with a scarlet glow. $A$ sinall tree of fine halit. Photograph at the right.

Pink Hawthorn (C. oxyeamtha rosea)

Pink flowers in May.

White Hawthorn (C. oxycantha alba)

$\checkmark$ Fragrant white flowers in May, and briglit red fruit in the Fall.

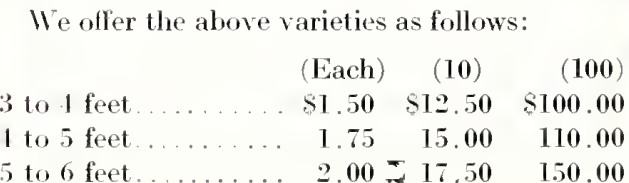

\section{MOUNTAIN ASH (Sorbus)}

American Mountain Ash (S. americana)

Brilliant slusters of bright red berries in the Fall.

1 to 5 feet $\begin{array}{cc}\text { Each }) & (10) \\ \$ 1.00 & \$ 8.00\end{array}$

5 to 6 feet $\ldots \ldots \ldots \ldots \ldots \ldots+1.50 \$ 8.00$

European (S. ancuparia)

A very attractive small lawn tree, with graceful, compound leaves which turn orange red in the Fall. Clusters of scarlet berries are borne in great abundance from July until Winter.

\begin{tabular}{|c|c|c|c|}
\hline & (Each) & (10) & $(100)$ \\
\hline 6 feet & $\$ 1.00$ & $\$ 9.00$ & $\$ 75.00$ \\
\hline & 1.50 & 12.00 & \\
\hline to $10 \mathrm{fe}$ & 2.00 & 17.50 & 150.00 \\
\hline 0 to $12 \mathrm{fe}$ & 3.00 & 25.00 & \\
\hline
\end{tabular}

10 to 12 feet...... $3.00 \quad 25.0$

Weeping (S. ancuparia peudula)

An umbrella-shaped variety with graceful drooping branches, resembling the Weeping Nulberry in habit.

$\begin{array}{ccc} & (\text { Each }) & (10) \\ & & \\ \$ 27.50\end{array}$

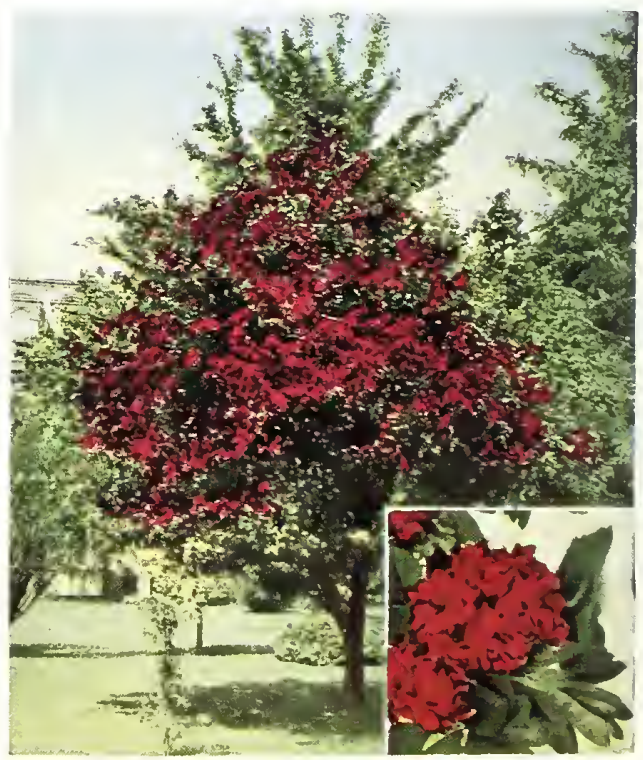

Paul's Scarlet Hawthorn Specimen 


\section{Flowering Trees From the Orient}

T $\triangle P A N$ and China have been particularly prolific in furnishing ${ }^{\top}$ s beatiful flowering trees and shrubs that are hardy and seem to be ideally suited to the $\checkmark$ chimate of Eastern North America. Perhaps not every variety on this page is of Oriental origin, but the beautiful Cherries, Cralss and Miaples are generally associated in this group. Very many desirable Oriental types are listed elsewhere in this Guide, and many more gladly quoled upon request. 'The finest effect of flowering trees is only obtained ly mass plantings, heautiful as they may be in single specimens.

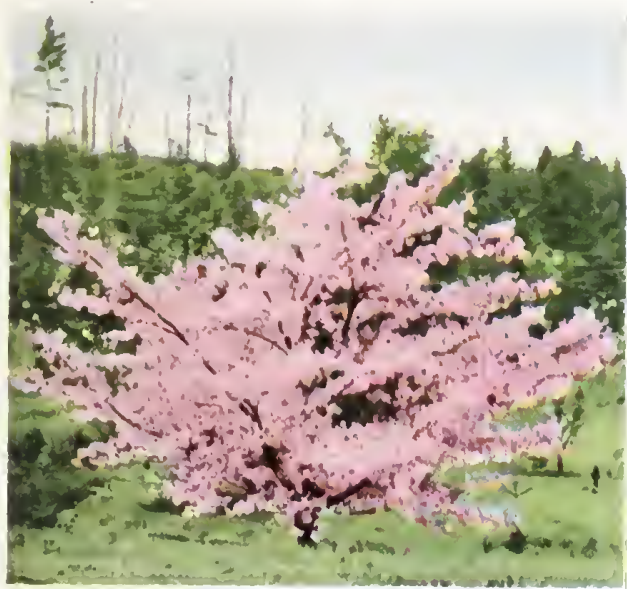

Pictured above is the Japminese Flowering Cherry - Ku'unzan

\section{JAPANESE FLOWERING CIIERRIES}

These are anong the very lirst things to bloom in the Spring ami extrencly choice and searce. We have several other varieties available in limited quantities. A small tree, entirely liardy. And notice these prices.

Vamed Varielie-as-as listed below.

to I feet.... (Wiach) $(10) \quad(100$ Olher sizes on request.

2.5 of one variety at the 100 rate.

Fugenzo (J. 11. Veilch-1)omble pink. Late. Narlen (cieboldi) (also called Kofugrui)-Donble pink.

Kwanzan (Sokizan) Donble olet rose.

Shimfugen-Donlule white, pink shating.

Joshino Clorry-Single pink. Fast growth. SIBERIAN UIEIPIT; CHERIR

A fine llowering tree witl single white hloxsoms. 6 foot stems. $\$ 3.00$

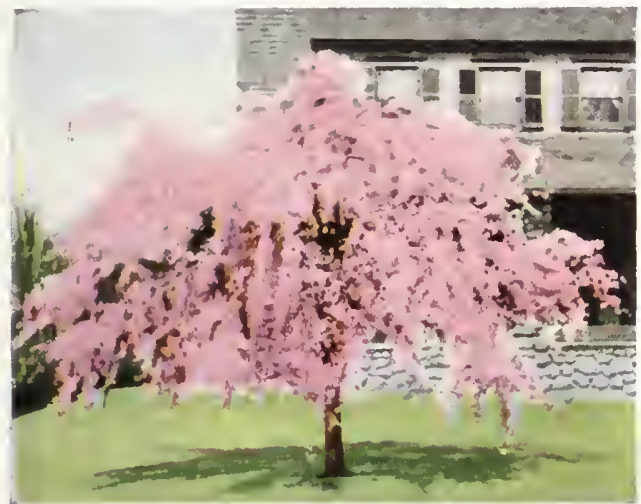

Japanese Heeping Cherry

\section{JAPANESE WEEPING CIIERR Y}

Among the mnusual frees cones this exotic, with delicate pendant brancles clothed in pink at the first wam weatler of Spring. It is harely and grows eisily, lut like most pendant types prefers a position sheltered from lieary winds.

IV. oller strong heads on 6 foot stenis realy to bear their lirst blowns this spring. 83.50 racli, $\$ 30.00$ for ten
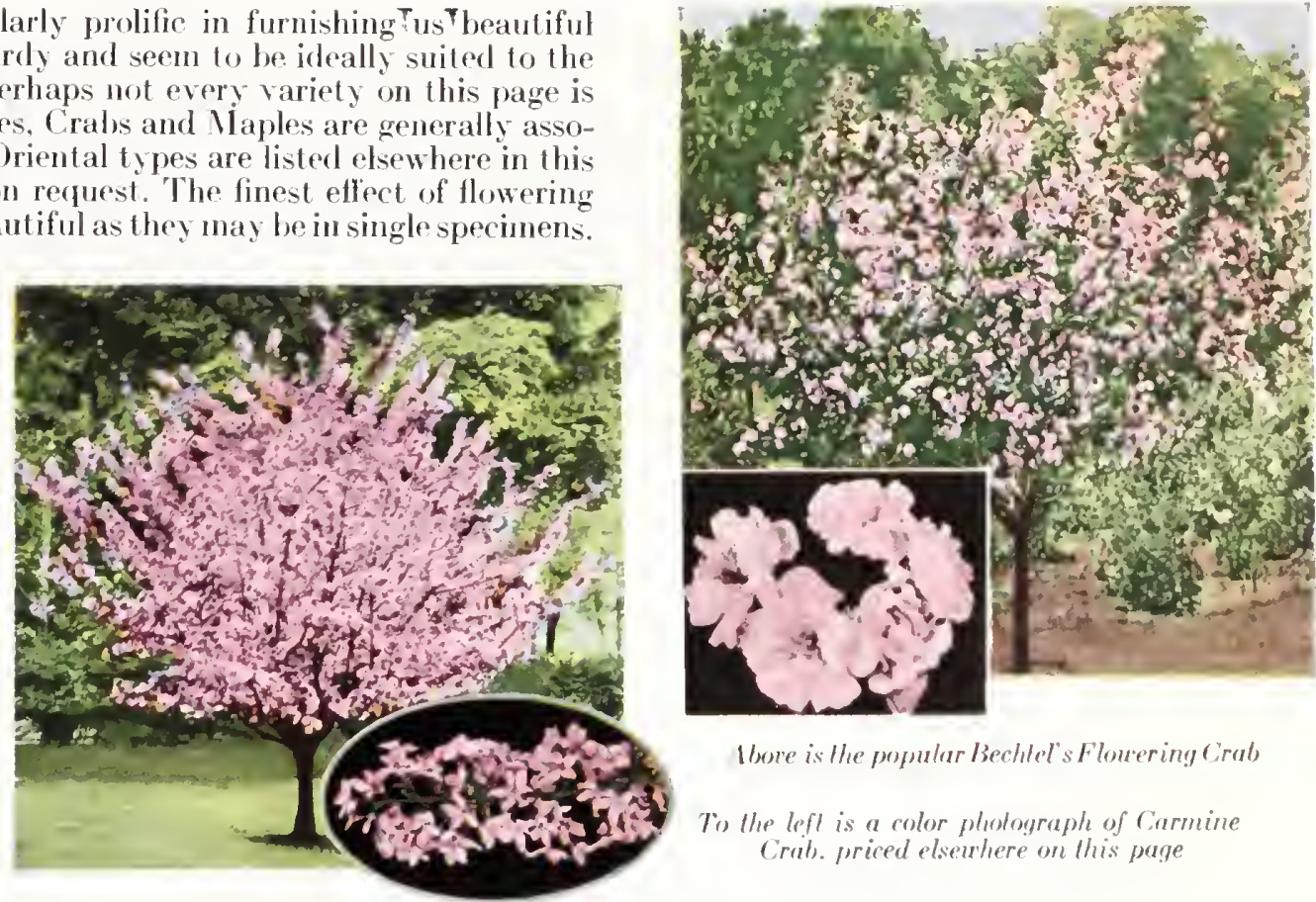

lbove is the popular Bechlel's Flowering Crab

To the left is a color plobograph of Carmine Crab. priced elsewhere on this page

\section{FIOWERING, CRIBS (Malus)}

These superb trees are elfective for kw n specimens, Int even nore important when userl plentifully in wookland and nases plantings, in the same way as bogwood and llawthorn.

There is a wide range of size and shape and color of blown and the following list includes only a few of those we are in a position to furnisl. The quantity prices are real hargains.

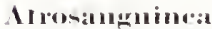

Carmine Crib.

3 to 1 feet

1. to 5 foet

Berhlel's Crals

1) onlile, pink.

3 to 1 forit

10.5 foret.

Florilominda

Single, rose pink.

3 to i foet

110.5 feet.

Voidawelayana, Redrein Crab

Entirely red-flowers, hranches, leives, and fruit.

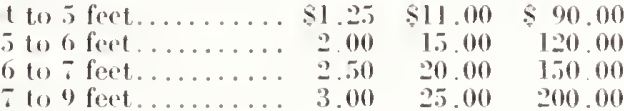

$($ Each $)(10)$
$\$ 1.00 \$ 9.00 \quad \$ 1 \% .00$

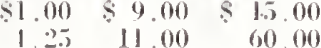

l'arkman-Cind

Demble rosi red Howers.

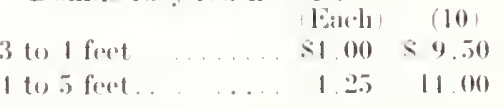

100)

cinginder.heri

lisly in bloont Rosy pink.

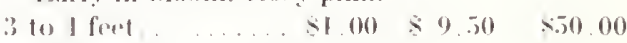

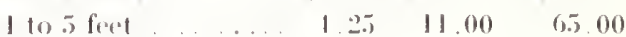

Viluevian M. baceatia

1 tall narrow tree, with snall white flowers.

2 to. 3 foet Each) $\quad 10$

3 to 1 foet

1 to 5 freel

5 to 6 foet
$100 \quad 9.50$

$1.25 \quad 11.00$

\section{The Bloodleaf Japanese Maple}

Were is a small tree (color plotograph on the right) which presents in spring what is perhaps the brightest, fullest color in Vature. Yet tho color seens perfectly natural, as intleed it is, being not uncommonly found growing wild in Japan.

We offer only true grafted types. They will retain their color practically all Summer, having been especially selected for propagating for that very reason. Ilakes a superl, lawn specimen. or may be used for nixed planting in the shrub border, where its brilliant coloring makes a striking ellect

15 to 18 inches

18 to 21 inches

$21021 \frac{1}{2}$ fret

( Eirch)

$2.00 \quad 37=$

$2.50 \quad 22.50$

$+00 \quad 3500$

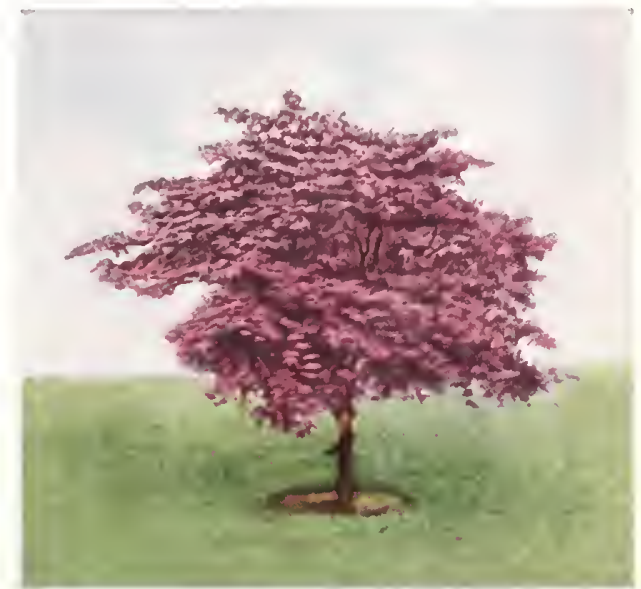




\section{Evergreen Trees}

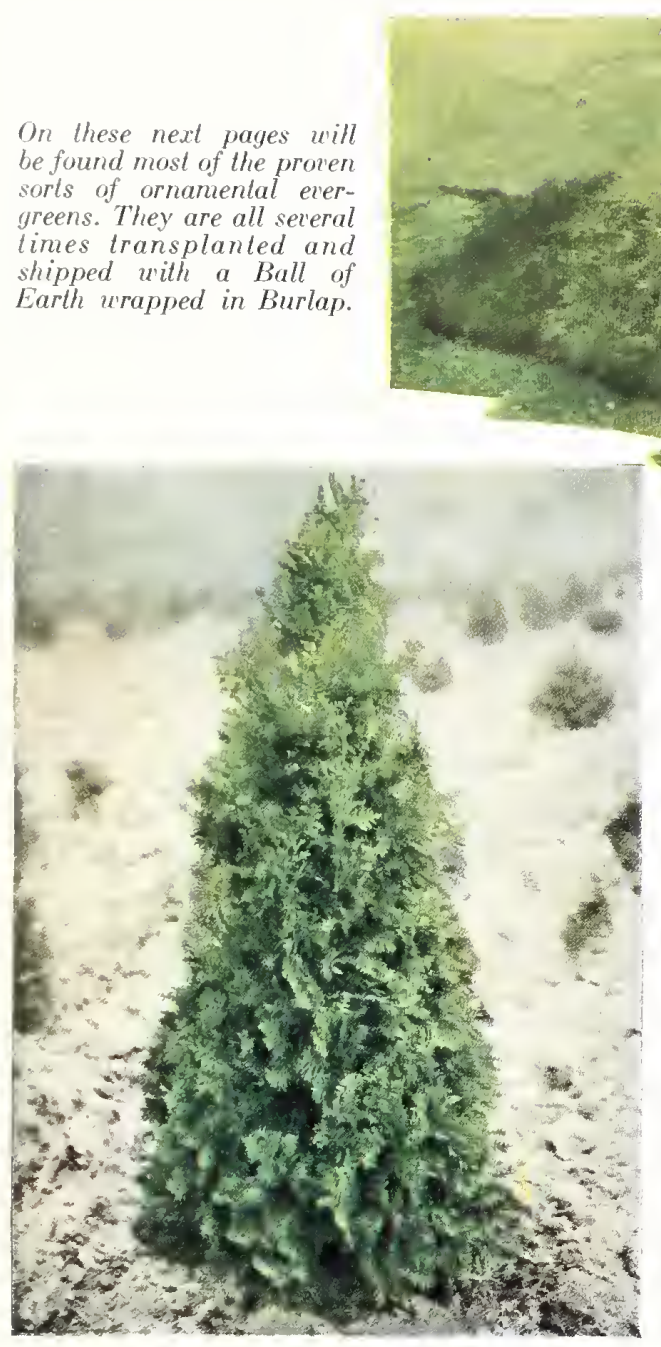

Pyramidal Arborvitae

\section{PYRAMIDAL ARBORVITAE}

This is perhaps the one best type of American Arborvitae or White Cedar. Its characteristics are clearly indicated in the alove color photograph. Very hardy. Ideal for formal narrow hedges, for whieh purposc wc offer a speeial size: 12 to 15 inches X. $\$ 28.00$ per 100. (\$240.00 per 1000). Larger sizes:

\begin{tabular}{|c|c|c|c|}
\hline & (Each) & (10) & $(100$ \\
\hline $\mathrm{EB}$ & $\$ 1.75$ & $\$ 15.00$ & $\$ 70.00$ \\
\hline & 2.00 & 18.00 & 125.00 \\
\hline 3 to 4 feet & 2.50 & 22.50 & 200.00 \\
\hline 4 to 5 feet. & 5.00 & 42.50 & 300 . \\
\hline
\end{tabular}

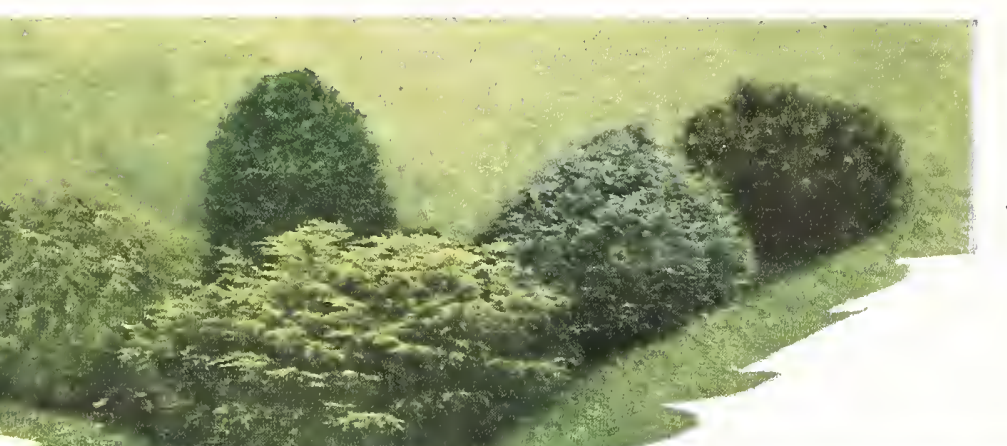

No brief list can pretend to name all the types of evergreens available. Will you kindly write for quotation if you want something you do not find here? Or special quantities or sizes?

\section{ARBORVITAE (Thuja)}

American Arborvitae (T. Occidentalis)

EIIK - 15 to 20 feet. Narrow pyramidal tree. Dark green foliage. Excellent as a hedge and special prices on sizes for this purpose listed in baek of the book.

Lining-out Stock (Each) (10) (100) 12 to 18 inehes XX. . ... .... $\$ 20.00$ Balled and Burlapped

$\begin{array}{rrrr}18 \text { to } 24 \text { inches.... } & \$ 1.25 & \$ 11.00 & 70.00 \\ 2 \text { to } 3 \text { feet...... } & 1.50 & 14.00 & 80.00 \\ 3 \text { to } 4 \text { feet ...... } & 2.25 & 20.00 & 95.00 \\ 4 \text { to } 5 \text { feet..... } & 5.00 & 47.50 & 300.00\end{array}$

4 to 5 feet $5.00 \quad 47.50-300.00$

Vervacn (T. oceid. vervaeneana)

A very hardy varicty which is broad, bushy and pyramidal. The foliage varies from a light greygreen to a yellowish green. On aeeount of its extreme hardiness, it should be used more extensively in foundation groupings having a blcak exposure.

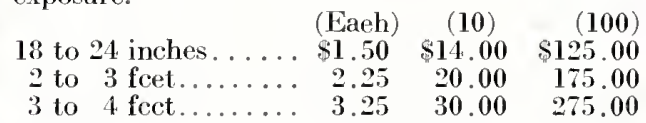

Woodward (T. oceid. woodwardi)

This splendid globe-shaped Arborvitae maintains itself well under all eonditions. It holds its shape without trimming. A good bedding variety.

(Each) (10)

15 to 18 inches........... \$1.25 $\$ 10.00$

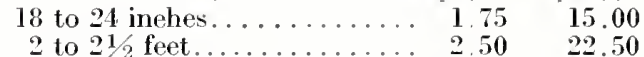

Gcorge Pcabody (T. oceid. lutea)

A distinct golden type of pyranidal outline.

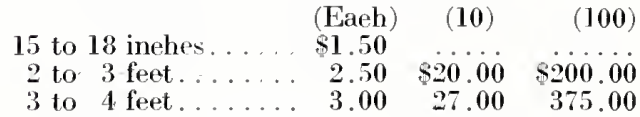

3 to 4 feet $. \cdots, 3.00 \quad 37.00$

\section{Rare and Unusual Evergreens}

We are able to offer at exceptionally low prices this season the following scarce and rare varieties. Both are hardy in sheltered positions as far north as Eastern Massachusetts. Many other similar varieties gladly quoted on request.

Cedar of Lebanon (Cedrus Libani)

Large tree, with widc-spreading, horizontal branehes. Round hcaded. Its beauty is historic, and the variety is of peeuliar interest for its religious assoeiations. The soft, pleasing foliage is unique. Gray-green in color

\begin{tabular}{|c|c|c|}
\hline & (10) & $(100)$ \\
\hline 18 to 24 inches & $\$ 20.00$ & $\$ 150.00$ \\
\hline & 32,00 & 270.00 \\
\hline & 40.00 & 350.00 \\
\hline 4 to 5 feet & 60.00 & \\
\hline 5 to 6 feet. & 80.00 & \\
\hline
\end{tabular}

Cryptomeria Lobbi Compaeta

15 to 20 feet. Pieturesque, narrow and compaet eolumn. Rieh bronze in Winter. This is unlike any other hardy evcrgreen in appearanee. The Lobbi varicty is much hardier than the ordinary Cryptomeria.

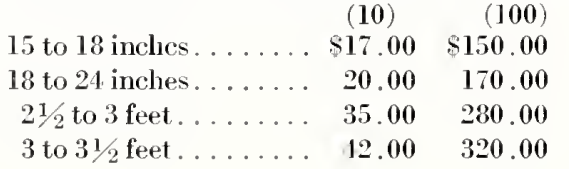

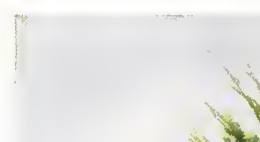

1
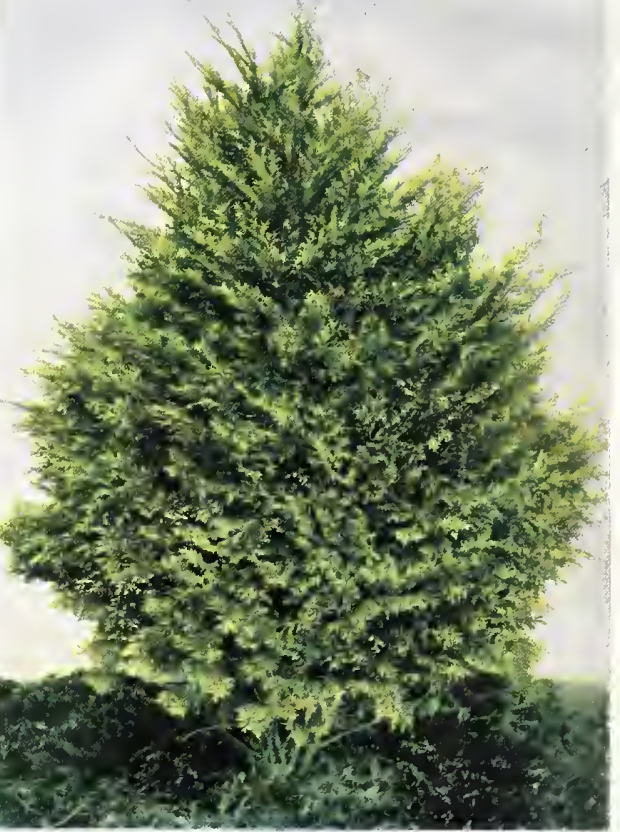

Golden Plumed Cypress

\section{JAPANESE CYPRESS (Retinospora)}

Golden Plnmed Cypress (pietured above)

EIK-15 feet. A tall pyramid with bright golden yellow tipped foliage, quite dense. Very popular and useful.

\begin{tabular}{|c|c|c|c|}
\hline & (Eaeh) & (10) & \\
\hline $11 / 2$ to 2 & $\$ 2.00$ & $\$ 15.00$ & $\$ 100.00$ \\
\hline $\begin{array}{l}2 \\
3 \text { to } 3 \\
\text { to } 4\end{array}$ & $\begin{array}{l}3.50 \\
5.50\end{array}$ & 16.00 & \\
\hline
\end{tabular}

Veitch's Silver Cypress (R.Squarrosa Veitehi)

EGIJ-10 to 15 feet. A very dense wide pyramid with beautiful silvery blue foliage, with a feathery soft texture.

12 to 18 inehes.

18 to 24 inehes.

$$
\begin{array}{lrr}
(\text { Eaeh }) & (10) & (100) \\
\ldots \ldots & \$ 12.00 & \$ 100.00 \\
\ldots . & 18.00 & 140.00
\end{array}
$$

2 to 3 feet

$35.00 \quad 285.00$

\section{Sawara Cypress (R. Pisifera)}

EHK-15 feet. Pyramid shape. Foliage bluish green. Very hardy.

18 to 24 inches...... $\$ 2.00 \quad \$ 12.00 \quad \$ 80.00$ 2 to $21 / 2$ feet....... $3.00 \quad 16.00 \quad 100.00$

$\begin{array}{lllll}3 \text { to } & 4 \text { feet....... } 4.50 \quad 30.00 \quad 150.00\end{array}$

Golden Sawara Cypress (R. Pisifera aurea)

Same as above, but with gold tipped branches. 18 to 24 inches..... $\$ 2.00 \quad \$ 18.00 \quad \$ 100.00$

2 to 3 feet..... $3.00 \quad 2-50 \quad 150.00$

3 to 4 feet......... $1.50 \quad 40.00 \quad 300.00$

Thread-bramehed Cypress (R. Filifera)

EK -8 to 10 feet. String-like dropping foliage Good green color. (Golden form of this variety quoted on request.)

18 to 24 inehes...... $\$ 2.00 \quad \$ 15.00 \quad \$ 100,00$ 2 to 3 feet...... $3.50 \quad 30.00 \quad 150.00$

$\begin{array}{llll}3 \text { to } & 4 \text { feet.......... } & 4.50 & 40.00\end{array}$ 


\section{The Junipers for Sunny Slopes}

$\mathbf{J}$ LNIPERS are sun-loving trees. Plant them on warm dry hillsides where other evergreens would not succeed, and the Junipers, once they have established themselves, will thrive exceedingly. There is an enormous range of shape and color - from the tall Red Cedar to the ground-covering Prostrate Juniper.

Gromud Junipor (J. Communis depressa)

EGK-3 to 4 feet. Gray green foliage and spreading to 10 fect or more. I seful to coverbanks or roeks.

18 to 21 inches. . $\begin{array}{lr}\text { (Each) } & (10) \\ \$ 2.00 & \$ 18.00\end{array}$ 2 to 3 fect .......... $2.50 \quad 22.50$

Common Golden Juniper (J. Canadensis Anrea)

EGK - 3 to 1 feet. Dwarf, spreading, fine golden color.

18 to 21 inclies. . . . . . . . . \$2.00 $\$ 17.50$ 2 to 3 freet.

$2.50 \quad 22.50$

Greek Juniper (J. Excolsa sitricta)

EGK-6 to 10 feet. A fine, dense, narrow column of pleasing color and texture.

12 to 15 inches. . . . . . . . . \$1.50 \$12.50

1.5 to 18 inclues............ $2.00 \quad 17.50$

Irislı Juniper (J. IIbreniea)

EIIJ -8 to 10 feet. A dense narrow column with light green foliage.

18 to 24 inches.......... $\$ 1.00 \$ 9.00$

2 to 3 feet..................... $1.50 \quad 14.00$

3 to feet.

$2.00 \quad 17.50$

Savin Juniper (J. Sabina)

EHK-4 to 5 fcet. Irregular shape. Dark green foliage. Spreading hranches.

18 to 24 inches... . . . . . . $82.50 \quad \$ 20.00$ 2 to 3 feet . . . . . . $3.50 \quad 30.00$

Swodish Juniper J. Comm. Succica)

EIIK- - to 8 feet. Like the Irish, but more bushy in growth.

18 to 24 inches............ \$1.25 \$12.00 $2 \mathrm{to} 3 \mathrm{frcl} \ldots \ldots \ldots \ldots \ldots \ldots 2.00 \quad 18.00$

Crecping Juniper (J. Sabina Tamariseifolia)

Ellk-18 to 21 inclies high-1 to 8 foot spread. Blueish-green foliage.

12 to 15 inclies.

$\$ 2.00 \$ 18.00$

18 to 21 incles.............. 30.50
Red Cedar (J. Virginiana)

EIIK-20 to 30 feet. I tall stronder column of dark green, dense and bushy. Iuch uved as an accent plant but also excellent in mass and field planting.

2 to 3 feet.

3 to + feet

1 to 5 feet

5 to 6 fect

6 to 7 feet

t to 8 feet

8 to 9 feet

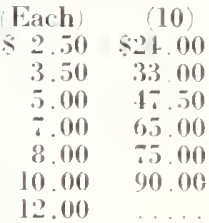

Blue Cedar J. Virgin. Glanca

EIIK-15 to 20 feet. Silver gray foliagevigorous.

18 to 24 inches $\$ 25.00 \$ 150.00$

2 to 3 feet ........... $3.5 .00 \quad 160.00$

\section{JUNIPERS IN SUALL SIZES}

Pasted inside the baek cover will be found a green price list of seedlings and transplants-stock small enough to loe shipped without a ball of earth. If a few years waiting is not a deterrent, large savings in cost may bc olotained by using these small sizes.

\section{Beautiful Silvery Pfitzer's Juniper}

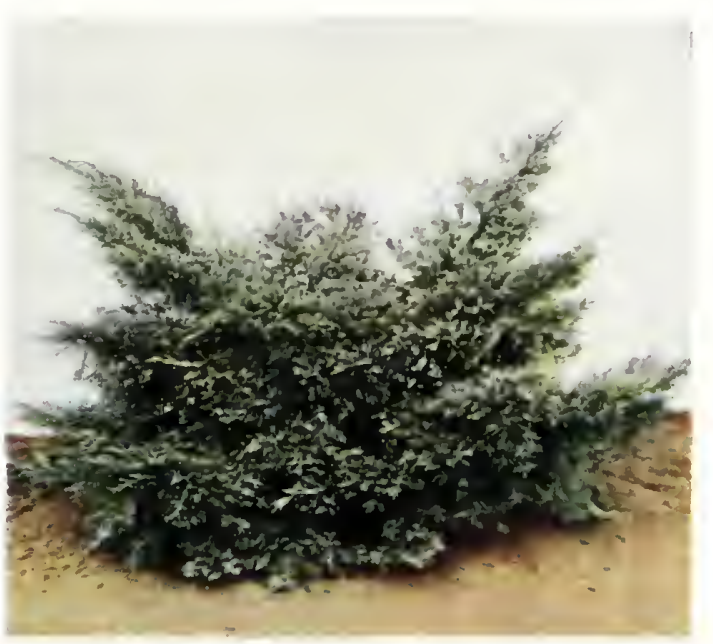

\section{J. P'fitzerianil}

EGK 4 to if feet. This is a grorereous dwarf. It makes a compact busll as liroad as it is high and with soft green sprealing foliage that is like a silver cloud in spring and early summer. Thrives under dillicult city conditions.

$\begin{array}{lrrr} & (\text { Each }) & (10) & (100) \\ 112 \text { to } 2 \text { fcet.... } & \$ 2.50 & \$ 2.50 & \$ 150.00 \\ 2 \text { to } 21,2 \text { fret.... } & 3.50 & 30.00 & \ldots \ldots \\ 21.2 \text { to } 3 \text { feet.... } & 1.00 & 38.00 & \ldots \ldots \\ 3 \text { to } 1 \text { feet ..... } & 6.00 & 55.00 & \ldots \ldots\end{array}$

to 1 feet $.00 \quad 55.00$

Sinaller and larger sizes are available and will be quoted upon request.

\section{Here are Some Real Evergreen Bargains}

THE following stock is all nursery grown, several times transplanted and bushs. It will be shipped with a ball and lurlap at these prices. The material is in surplus and this offer is designed to clear the gromnd. This is an unprecedented opportunity: All eastern grown, 25 may be ordered at the 100 rale given. All prices net, truching or transportation will be undertaken, however, at actual cost. Not less than 25 of one kind can he ordered at these prices.

\section{PINES}

\section{Instrian}

2 to 3 feet

Norway liad

$11 / 2$ to 2 feet

2 to $3 \mathrm{fret}$

3 to 1 feet

4 to 5 feet

Japanese lied

5 to 6 feet. Thinly branched

\section{FIRS}

Donglas Fir

18 to 21 inches.

2 to 3 feet

3 to 4 feet.
IIEMLOCK

\section{Each Cantulium}

$\$ 1.00 \quad 18$ to 21 inches.

\section{IEW}

Jap. Spreading

12 to 15 inches.

1. 2.5

2.80

1.00

18 to 21 inches.

2 to 3 feet

Ameriean

2 to 3 feet. .

\section{CYPRESS}

Retimospora pisifera anrea. (Golden) 18 to 21 inches.

2103 fert
R. pisifera

(Each) 18 to 21 inches.

2 to 3 feet

R. Plumoma anroa Golden

181024 inches.

$\$ 1.00$

2 to 3 feet

Ii. filifera

18 to 21 inches.

2 to 3 feet

(Each)

s. 80

1.00

1.00

1.00

1.50

$8 . .70$

.80

I'fitzer's

18 to 21 inches.

Virg. glanca

$81.00 \quad 2$ to 3 feet

\section{JUNIPERS}




\section{The Pines (Pinus)}

$\mathrm{P}$ ROBABL I ro tree in Nature has so much sentiment attached to it for so just a cause. The appearance is typical of rugged strength, which the character of the tree bears out. Far up on nountain ranges where the snow line commences, a few straggling trees battle with the elements. And the last tree of all, twisted and stunted, is more often than not a Pine tree. Ind this same Pine species, taken into cultivation and given care and opportunity, becomes a full bushy specimen, its soft outline and texture of long thickly bundled needles contrasting pleasingly with every other kind of evergreen.

Pine trees will grow well in any good soil-but also do well on gravelly or even sandy ground. The Austrian Pine will grow in sea-sand; the Scotch Pine will grow in soil so poor that no other evergreen can thrive.

\section{White Pine (Pinus strobus)}

EHK- -60 to 100 feet. The finest native variety. Soft dense foliage and majestic spreading form. A variety to be planted in good soil. Unfort unately subject to a blister rust, and severely quarantined for this reason. Prices quoted on request, but small sizes listed in the green price list at the back.

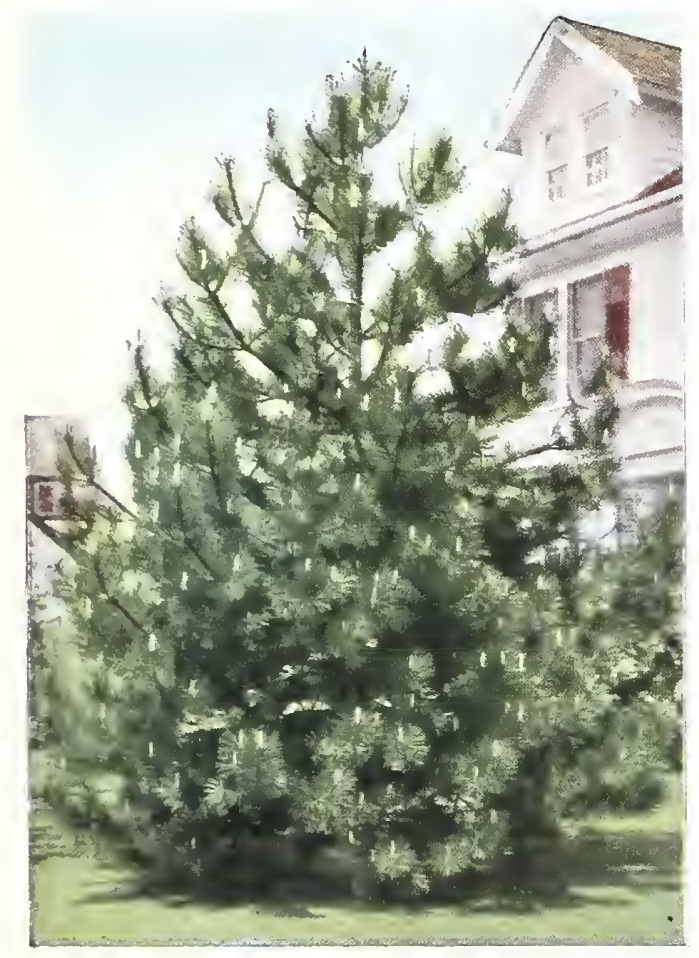

Austrian Pine

\section{THE AUSTRIAN PINE}

This variety of the Black Pine is perhaps the best of the European pines. Properly named Pinus nigra var. italica. it is called in commerce Pinus Austriaca. It is hardy, fast growing and succeeds in a wide variety of soil-even along beaches subject to the salt spray of the sea. It is much used as a wind break in estates near the ocean, but is equally adapted for forestry planting. Single specimens and groups for ornaments make a magnificent appearance, since its ultimate height is only 40 to 50 feet and the variety keeps within hounds of reasonable size. We offer:

\begin{tabular}{|c|c|c|c|}
\hline & (Each) & (10) & (100) \\
\hline 18 to 21 inches. . . . . . & $\ldots$ & $\$ 12.50$ & 890.00 \\
\hline 2 to 3 feet... & $\$ 3.00$ & 15.00 & 100.00 \\
\hline 3 to 1 feet. & 1.50 & 25.00 & 200.00 \\
\hline 4 to 5 feet. & 6.00 & 55.00 & \\
\hline
\end{tabular}

\section{Japanese Red Pine (P. Densiflora)}

EHK-10 to 60 feet. Long bright green needles. An open headed tree, densely branched. Good for seashore planting.

\begin{tabular}{lrrr} 
& (Each) & \multicolumn{1}{c}{$(10)$} & $(100)$ \\
3 to 4 feet ......... & $\$ 3.00$ & $\$ 25.00$ & $\$ 200.00$ \\
1 to 5 feet......... & 4.50 & 10.00 & 350.00
\end{tabular}
5 to 6 feet. Hedge grade $\ldots . . . . \quad 100.00$

\section{Int roducing}

\section{THE RIGA (SCO'TCH) PINE}

(Pinus Sylvestris var. Rigensis)

The Scotch Pine (Pinus Sylvestris) has many varieties, called geographical varicties. The differences are slight with the exception of the variety that grows in Finland around the Gulf of Riga. This has long been known among foresters as a type altogether superior to ordinary Scots Pine.

Where the type grows straggly and with a crooked leader, the Riga variety puts up a straight clean trunk. The color of branches is striking-noticeably reddish. The needles do not turn so yellow in Spring as those of the type. The Riga Pine also has a much longer life and makes a much grcater height, up to 80 and 100 feet or more.

The Riga variety may be planted wherever ordinary Scotch Pine will thrive. It will succeed as well and look better.

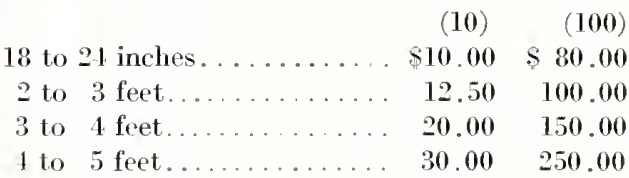

\section{THE MUGHO PINE}

Mugho Pine (Pinus Montana, var. Mughus)

EGK- 6 to 8 feet. A dense low-spreading evergreen, being a variation from the Mountain Pine of Europe. One of the finest dwarfs. Since it is a variation, the strain of seed used is of the utmost importance. We try to have all our Mugho Pine rcal dwarf forms, raised from selected seed. This year we offer an unusual bargain.

$\begin{array}{rrrr}10 \text { to } 12 \text { inches..... } & \text { (Each) } & (10) & (100) \\ 12 \text { to } 15 \text { inches ..... } & \$ 1.00 & \$ 9.00 & 80.00 \\ 15 \text { to } 18 \text { inches..... } & 1.50 & 14.00 & 125.00 \\ 18 \text { to } 24 \text { inches...... } & 2.00 & 17.50 & 150.00\end{array}$

The color photograph on the right shows a specimen Mugho Pine about three to four feet broad. It is very slow growing and retains its duarf nature for thirty years or more.

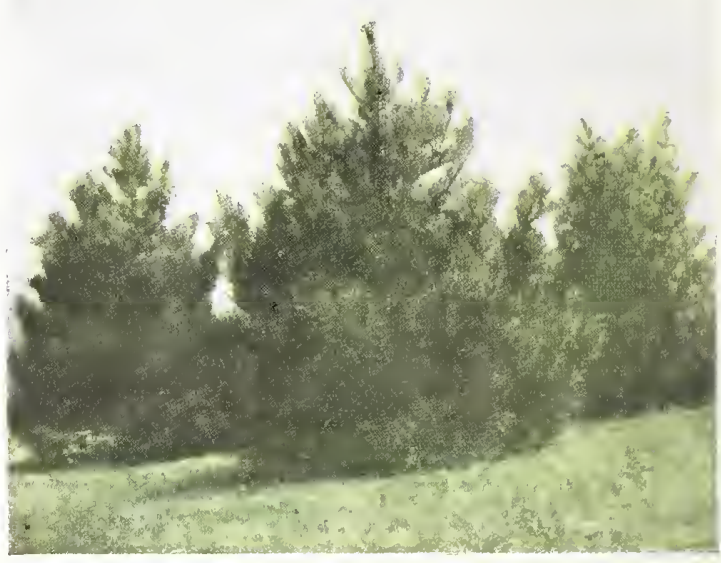

\section{THE RED (NORWAY) PINE}

The Pinus Resinosa is probably the one most popular cvergreen for all purposes. It is a native to the Eastern parts of the country and absolutely hardy. Its name is taken from the town of Norway, Maine.

In forestry, it makes valuable timber and quick growth on even the poorest of soils. In large quantities we are prepared to quote exceptionally low prices.

As a specimen, it grows into a tall, spreading, imposing tree, and is very long lived. The bark is red. This variety is notable because of its freedom from most insect pests.

$\begin{array}{rrrr} & \text { (Each) } & (10) & (100) \\ 18 \text { to } 24 \text { inches..... } & \$ 1.25 & \$ 10.00 & \$ 90.00 \\ 2 \text { to } 3 \text { feet....... } & 1.50 & 13.50 & 125.00 \\ 3 \text { to } 4 \text { feet....... } & 3.00 & 20.00 & 180.00 \\ 4 \text { to } 5 \text { feet ........ } & 5.00 & 47.50 & 280.00 \\ 5 \text { to } 6 \text { feet....... } & 7.50 & 70.00 & 4.00 .00\end{array}$

This season we have an exceptionally attractive bargain in this variety for mass plantings, screens, etc.

$(100) \quad(1000)$

$18,000,18$ to 30 inches, (twicc

transplanted, bushy)...... \$22.00 \$160.00

This price is low because the land must be cleared this season. It is impossible to buy such stock for twice the money in the wholesale market.

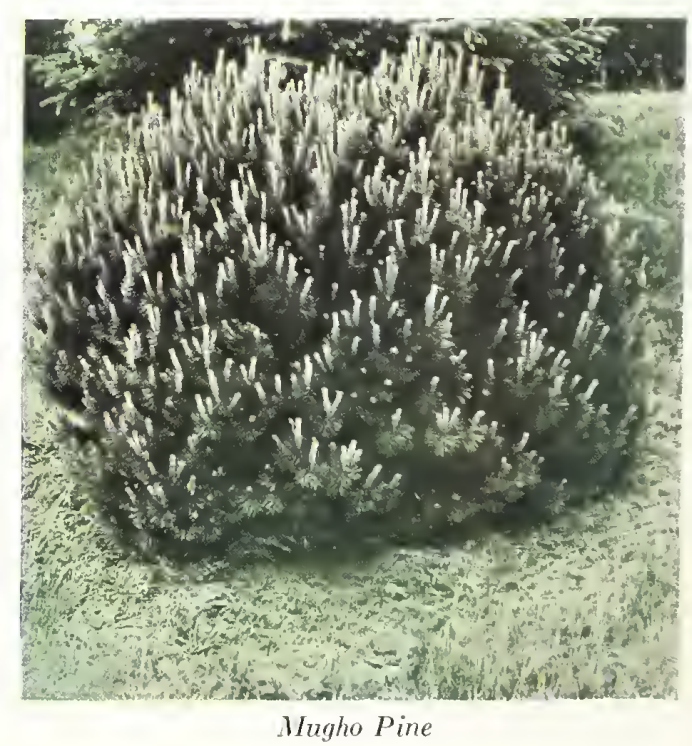




\section{Spruce and Fir}

$\mathrm{T}$ YHESE upright, pyramidal everoreens are quite similar in general appearance. The Spruces are a harly and tolerant race and range from the well-known Vorway Spruce lo such types as Koster's Blue and on the other side of the scale, the dwarf Pygmy Spruce. The Firs are delighlful and perhajs retain their appearance for a longer number of years. The foliage is longer and not so stiff. These pages ofler only a few hinds, others gladly quoled on request.

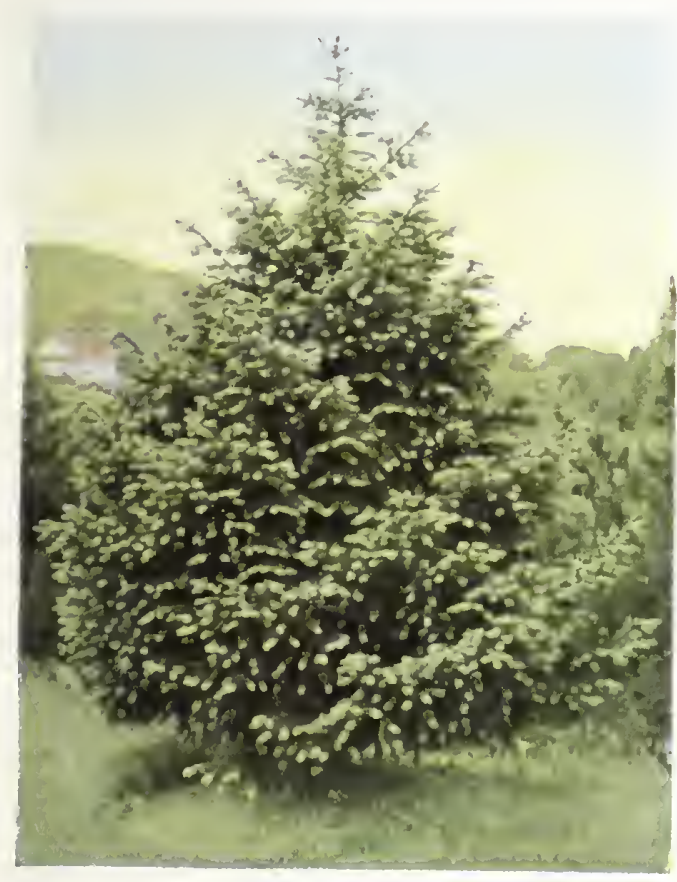

Monglas Fir

Domglas Fir (Porendotomgat)

EHh-10 to 50 feet. Compart dense foliage dark green. I suproh, variety everllent. for mass planting. I'ictured above.

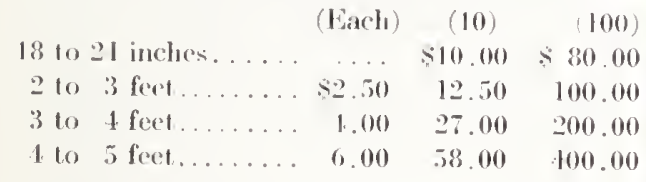

Silver Fir (1. Comeolor)

EIH - 10 to .00 fort. Dense pramidal sliape, foliage silver to stocl blue. Wakes a sploudid specinren.

$\begin{array}{rrrrr}18 \text { to } 21 \text { inches. . . . } & \$ 2.50 & \$ 2.30 & \$ 1.50 .00 \\ 2 \text { to } 3 \text { feet . . . . . } & 1.00 & 35.00 & 200.00 \\ 3 \text { to } 4 \text { feet } \ldots \ldots \ldots . & 5.50 & 60.00 & 500.00\end{array}$

Nikkn (1. Homolepis

Ellk-60 feet. 'The darh groen leaves are silvery white beneath.

$\begin{array}{rrrr}18 \text { to } 21 \text { inches. . . . } & \$ 2.50 & \$ 2.2 .50 \\ 2 \text { to } 3 \text { feet . . . . . } & 3.00 & 27.50 \\ 3 \text { to } 1 \text { foet . . . . } & 5.00 & 16.00\end{array}$

\section{Vurcls"s Fir (1. Veilrhii)}

EIIK-50 to 60 fret. Long dark green needles.

Narrow pyramidal tree. Soft textmre.

2 to $21 / 2$ feet

$21 / 2$ to 3 feet

$\$ 3.00 \$ 27.50$

3 to 1 feel

$\begin{array}{ll}1.00 & 3.50 \\ 5.00 & 1.5 .00\end{array}$

\section{TIHE BLUE SPRUCES}

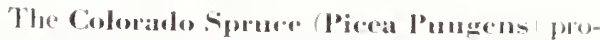
tuces both green and blue trees from its seed The best of the blue trees are selected and sold as Colorarko Bhue spruce. We oller the following carefully selected specinnens. IIl are of a definite bhe color, although not as miform in tome as hoster's lilue Spruce.

\begin{tabular}{|c|c|c|c|}
\hline & (tach) & (10) & 100 \\
\hline 12 to 18 inches. & $\$ 3.00$ & $\$ 30.00$ & 52.5000 \\
\hline 18 to 21 inclues. & 1.00 & 10.00 & 300.00 \\
\hline 2 to 21/2 feet & 5.00 & 5000 & 100.00 \\
\hline
\end{tabular}

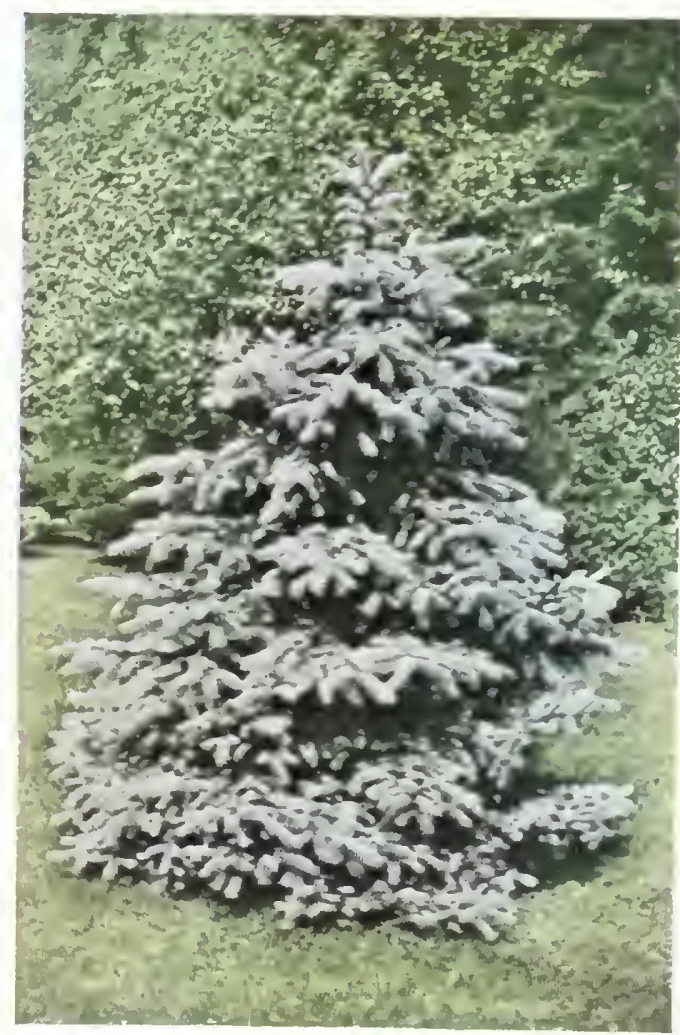

Koster's Blue Sprure

\begin{tabular}{|c|c|c|}
\hline 3 to $3 \frac{1}{2}$ freel & 0.00 & 00.00 \\
\hline 312 to 1 feet & $\because .70$ & 7.00 \\
\hline 1 to $1 \frac{1 / 2}{\text { feet }}$ & 10.00 & \\
\hline
\end{tabular}

Kasler:- IBlue Spruere is a gralted form of the above. It is a betler and more endming color. Pictured above.
1.5 to 18 inches
$\$ \pi .00 \$ 17.00$
18 to 21 incher.
$7.00 \quad 0.5 .00$
$21021_{2}$ feet
21,2103 feet
10.00
12.00

TIIE PYGIIY SPRTCE

In odk rarity. "liny nomlles that searely soent

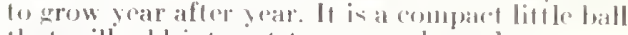
that. will adle interest to an! bock garden.

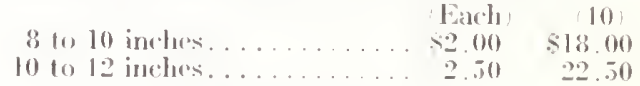

\section{THE WIITE SPRICE (I'irea alba)}

This variof mahes a shafoly pramialal tree and is one of the quickest growing sproces. being

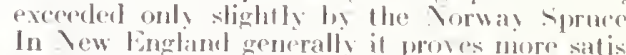
ficlory than lhis latler varicly and forms a

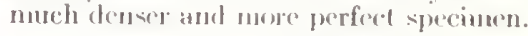

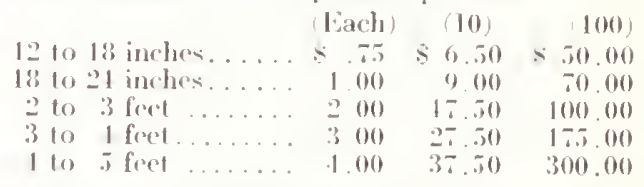

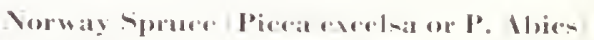

lillk - 0 to 70 feet. It malarity a lalt dark grecoll pramid with pomblous ahest wreping rason Jorwas soruce cam be planted in thin soils, wer latrd-pan or bod roch. Ils groil yopularity atlests its fumblamental virfues. Coler photograph boldu.

\begin{tabular}{|c|c|c|c|}
\hline 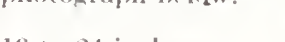 & land & 10 & 100 \\
\hline 18 to $21 \mathrm{im} \cdot$ & $\therefore .75$ & $\$ 0.50$ & $\therefore 00.00$ \\
\hline 2 to 3 feet & 1.00 & 9.00 & 80.00 \\
\hline 1 feet & 2.00 & 18.00 & 17.0 .00 \\
\hline
\end{tabular}

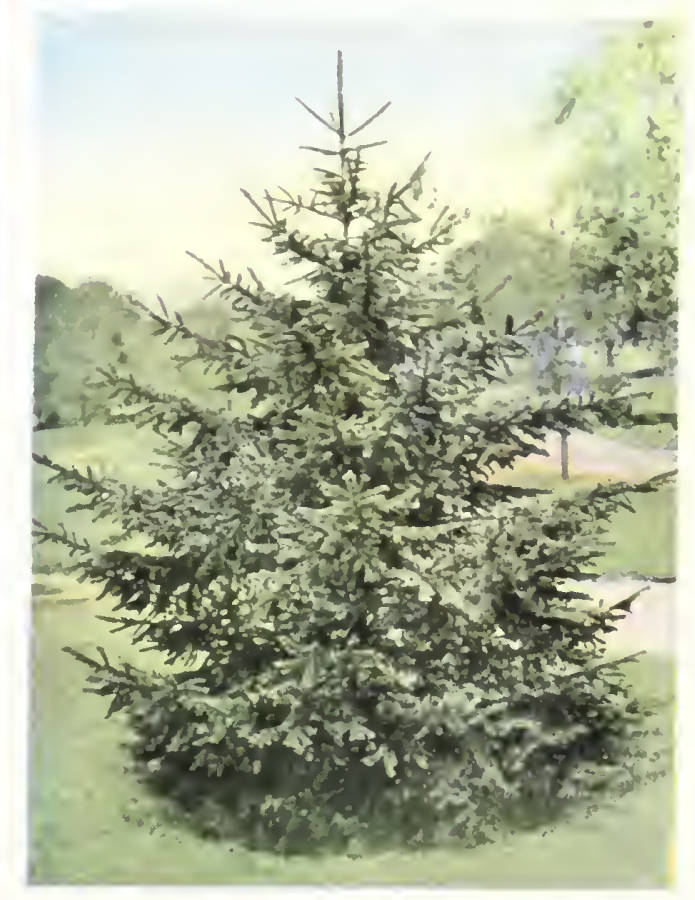

Noruay Spruce 


\section{Hemlock and Yew in the Shade}

$\mathrm{B}$ OTH these evergreens in all their varieties can be successfully grown in the shade as well as in sunlight. For this reason they are of unique usefulness. Fortunately, also, they rank as undoubtedly the two finest ornamental conifers hardy in our climate. Both will withstand shearing, if a hedge be desired, and not only stand it, but be much the better and bushier as a result.

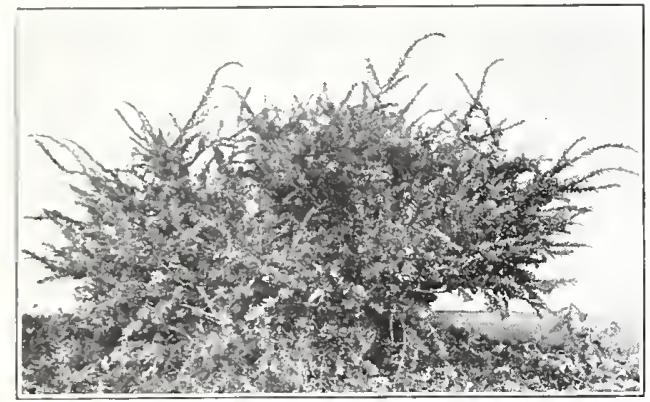

\section{AMERICAN YEW}

\section{T. Canadensis}

FGK-A dwarf spreading cvergreen. Its the foliage is thick and needles prominent. A good border edging.

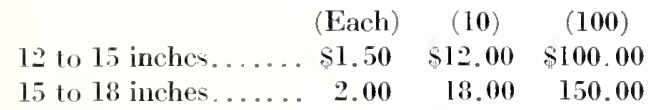

Upright American Yew (T. Canad. stricta)

Here is a worthwhile novelty. Dense ascending branches give this hardiest of all Yews a new shape and new uses.

(Each) (10)

$\begin{array}{rrr}9 \text { to } 12 \text { inches........... } \$ 1.25 & \$ 11.00 \\ 12 \text { to } 15 \text { inches........... } & 2.50 & 22.50\end{array}$

$\begin{array}{rrrr}12 & \text { to } 15 \text { inches............ } & 2.50 & 22.50 \\ 15 \text { to } 18 \text { inches........... } & 3.00 & 27.50\end{array}$

Here is the best Yew for hedgesraised from seed. Picture shows a 15 to 18 inch trec ready to ship.

(10) $(100)$

15-18 in. $\$ 17 \quad \$ 135$

18-24 in

$20 \quad 160$

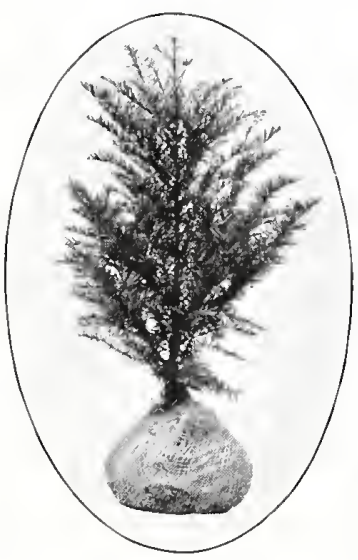

Improved Japanese Yew (T. cuspidata branches are ahmost fernlike in spread, although

\section{JAPANESE YEW \\ UPRIGITT FORMI}

\section{JAPANESE YEW}

Japance Yew (Taxus cuspidata)

The most common form. A spreading bush, about twice as wicke as high. Very hardy. Responds eagerly to shcaring as for a hedge, atthough the upright form is better for this purpose.

(Each) (10) (100)

12 to 15 inches...... $\$ 2.50 \quad \$ 24.00 \quad \$ 100.00$ 18 to 24 inches.... $\quad 3.50 \quad 32.50 \quad 200.00$ 2 to $21 / 2$ feet....... $5.00 \quad 45.00 \quad 425.00$ $21 / 2$ to 3 feet....... $7.50 \quad 70.00 \quad 650.00$

Dwarf Japanese Yew (Taxus brevifolia or nana)

Extremely slow growing and with denser, shorter needles than ordinary Japanese Yew. The one finest rock garden specimen-picturesque form.

12 to 15 inches..... $\$ 3.75 \quad \$ 35.00 \quad \$ 250.00$ 15 to 18 inches.... $44.50 \quad 42.00 \quad 400.00$ 18 to 24 inches.

7.50

12.00

..... intermedia)

A cross between the Japanese and dwarf Japanese. We offer two forms, the type-intermedia-and an upright form-columnaris. Both are pictured below.

\section{T. Cuspidata intermedia}

12 to 15 inches..... $\$ 2.50 \quad \$ 24.00 \quad \$ 220.00$ $\begin{array}{lllll}15 & \text { to } 18 \text { inches..... } & 3.50 & 32.50 & 300.00\end{array}$ 18 to 2.1 inches..... $5.00 \quad 48.00 \quad 450.00$

T. Cusp. Inter, columnaris

15 to 18 inches. . . . . $\$ 2.50 \quad \$ 20.00 \quad \$ 175.00$ 18 to 24 inches..... $\quad 3.00 \quad 27.50 \quad 250.00$ $\begin{array}{lllll}2 \text { to } & 3 \text { feet....... } & 4.00 & 37.50 & 350.00\end{array}$ $\begin{array}{lllll}3 \text { to } & 4 \text { feet....... } & 7.50 & 70.00 & 650.00\end{array}$

We have available many other kinds of Yew. Write for prices on anything you need. Smaller sizes in these and many other kinds will be found in the green price-list pasted inside the back cover.

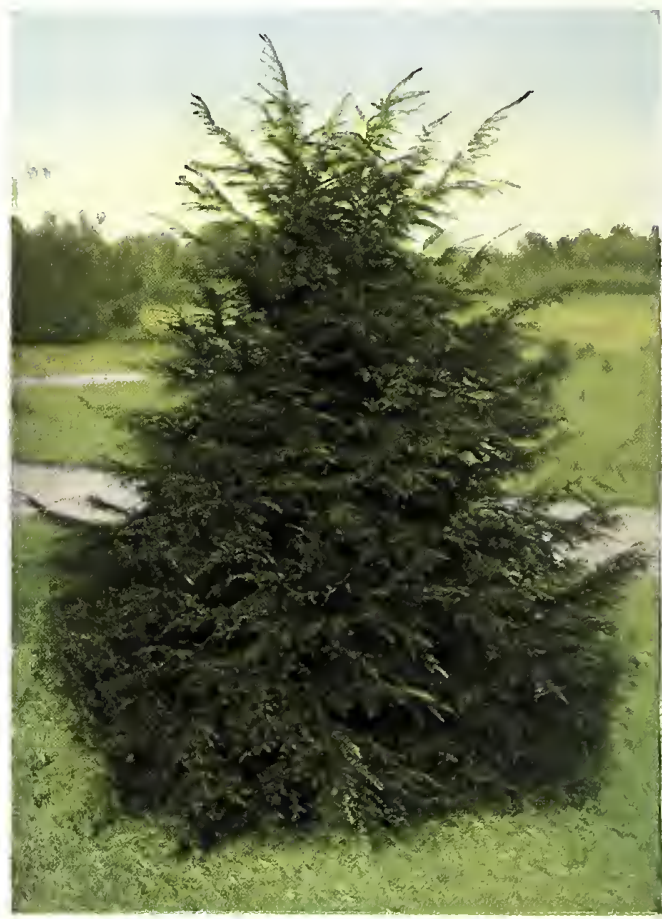

A fine young IIenlock Specimen

\section{HEMLOCK ('Tsuga)}

This is a glorious tree. It thrives in a range of soils and will succeed both in sun and shade. Do not, however, plant in windy, exposed situations. The foliage is black green and form graceful. It is hardy and easily grown. One of the very finest of our native conifers.

\section{American Hemlock (T. Canadensis)}

FHJ -60 to 70 feet. A superb tree that thrives in shade and with drooping spreading foliage. Makes a beautiful hedge and can be easily pruned. The color photograph above shows a nice specimen 8 to 9 fect high.

(Each) (10) (100)

2 to $21 / 2$ feet....... $\$ 1.50 \quad \$ 14.00 \quad \$ 95.00$

$21 / 2$ to 3 feet....... $3.00 \quad 27.50 \quad 260.00$

3 to $31 / 2$ feet....... $4.00 \quad 37.50 \quad 350.00$

$31 / 2$ to 4 feet...... $5.00 \quad 47.50 \quad 450.00$

4 to 5 feet........ $6.00 \quad 57.50$

5 to $51 / 2$ feet...... $8.00 \quad 75.00$

\section{A HEDGE OF}

\section{THE JAPANESE YEW IN PICTURES}

\section{HEMLOCK}

No one who has seen a Hemlock hedge in its soft, dense beauty can ever forget it. Small plants around a foot or more in height should be planted cighteen inches apart. Larger stock, say three feet high can be planted two and a half feet apart. As the hedge grows, it should be kept trimmed widest at the bottom. A six foot hedge should be three to four feet wide; a ten foot hedge about six feet wide. 


\section{Evergreen Hedges and Screens}

$\mathrm{W}$ THEN Winter winds blow and trees stand bleak and bare, only an evergreen hedge gives both protection and beauty. No other hedge can compare in value and usefulness. There are many species and varieties suitable to this work and only a few of the more notable ones are here mentioned. We recommend that inquiry be sent us for recommendation and quotation on your particular problem. We will answer promptly and quote our lowest prices.
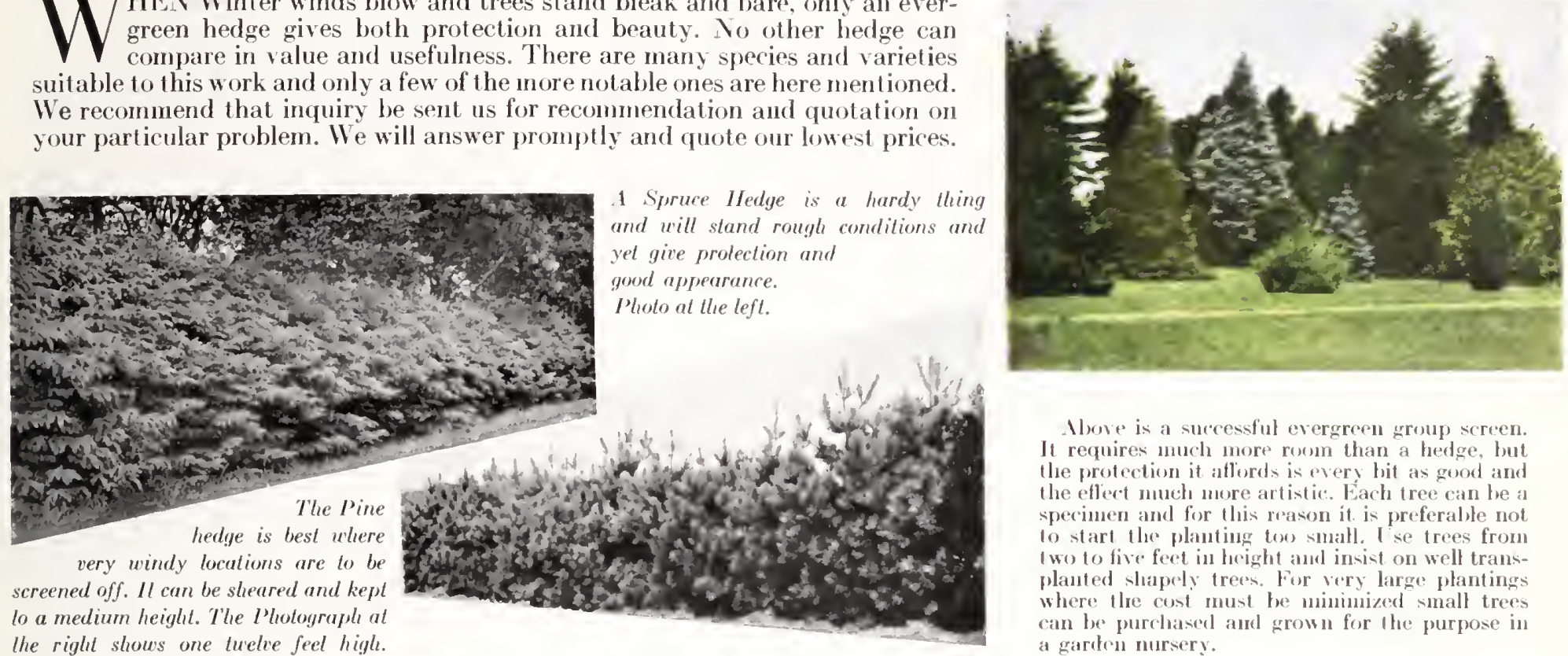

Mlowe is a successful evergreen group screen. It requires unch more room than a hedge, but the protection it aflords is pvery hit as good and the eflect nuch more artistic. Each tree can be : specimen and for this reason it is preferable not lo start the planting tox small. [ se trees from two to five feet in height aud insict on well transplanted shapely trees. For very large plantings where the cost must be minimized small trees can be purchased and grown for the purpose in a garken nursery.

\begin{tabular}{|c|c|c|c|c|c|}
\hline \multicolumn{2}{|c|}{ PINFS (Pinus) } & (Inclies) & (Tran<plinted) & (100) & $(1000)$ \\
\hline 17,000 & Hed (resillosa) & 18 to 30 & (wice (busliy) & $\$ 22.00$ & 8160.00 \\
\hline 25,000 & Austrian & 15 to 22 & once (liglit) & & 50.00 \\
\hline 4,000 & Austrian & 18 to $2 \mathrm{k}$ & (wice (busliy) & 28.00 & $2: 3,00$ \\
\hline 12,000 & ligiga Scotch & 121018 & once (good) & 0.00 & 15.00 \\
\hline 2,000 & liiga Scotch & 181021 & twice (heavy) & 10.00 & 80.00 \\
\hline 1,000 & Mugho dwarf & 10 to 12 & twice (busliy) & $\because 0.00$ & 180.00 \\
\hline \multicolumn{6}{|c|}{ SPRUCES (Picea) } \\
\hline 2,000 & Colorado (Bhue and Green) & 8 to 12 & fwice (lusliy) & 20.00 & 190.00 \\
\hline 8,000 & Englenum blue & 9 to 12 & once (bushy) & 23.00 & 180.00 \\
\hline 1,500 & Englemann blue & 121016 & once (bushy) & 33.00 & \\
\hline 10,000 & White (alba) & 10 to 15 & three (fine) & 12.00 & 90.00 \\
\hline 10,000 & Norway (excelsa) & 12 to 18 & twice (bushy) & 9.00 & $\because 2.00$ \\
\hline \multicolumn{6}{|c|}{ FIRS (Abies) } \\
\hline 5,000 & Concolor (Silver) & 8 to 10 & once (light) & 8.00 & 6.5 .00 \\
\hline 3,000 & Concolor (Silver) & 3 to 10 & twice (bushy) & 18.00 & 110.00 \\
\hline $5,000 \quad 1$ & Dourlas & 10 to 15 & twice (bushy) & 20.00 & 150.00 \\
\hline \multicolumn{6}{|c|}{ IIEMLOCK ('Isuga) } \\
\hline 2,400 & Canadian & 12 to 15 & twice (lushy) & 1.5 .00 & 380.00 \\
\hline
\end{tabular}

YEW (Taxus) 225 Cuspidata tree form sheared, I3, \& B.

15 to 18

three (heass)

13.5. 00

1200.00

ARIBORVITAE ('Thuja)

4,700 J'yramidal

12 to 15

once (nice)

23.00

210.00

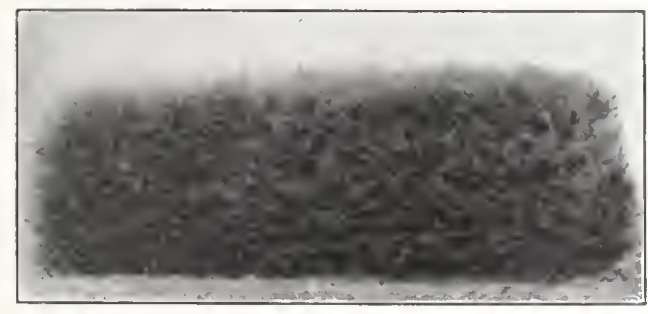

Ind many ot her kints as well as larger sizes available. Il rite for prices on your needs.

The color photograph below shows a thoronghly protected drivenav. Here usefulness is so wedded to beauty lhat the result is 1rt of a high order.

\section{A HEDGE OF JAPANESE YEW}

Above is a small section of Yew luedge that shows this species' unique adaption to the purpose. On the opposite page we offer tlue ideal plant for this purpose--Japanese Y ew from seed. The late Dr. Wilson of the Arnold Arboretum recommented this type as the very best Iew hedge for North America.

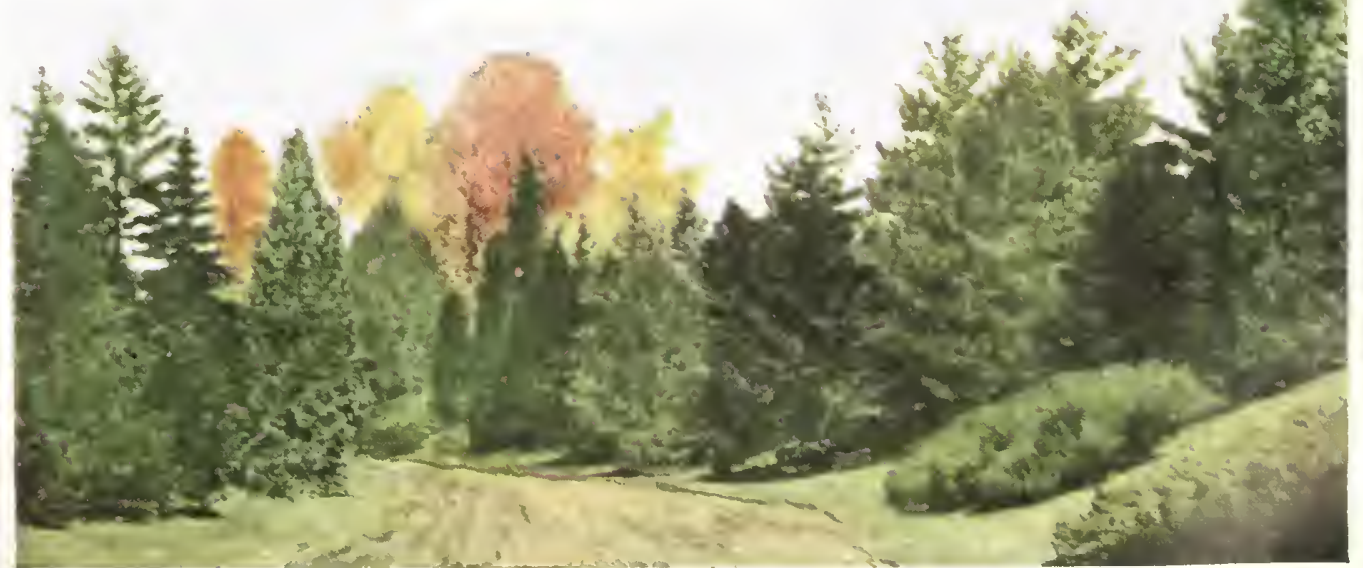




\section{Rhododendrons}

Thlle following nalive types have all been mursery grown, are bushy and well Irausplanted. Furnished B. \& B. from Massachuselts. Collected plants quoted at very low prices at the hottom of this page.

Rhododendion Caroblina

Fh-8 to 10 foret. line natives with liobt to deep pink lowern in dune.

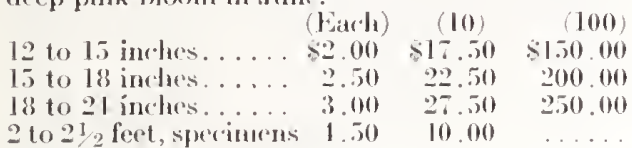

Caroliua alloa

Same as above with whitr How

15 to 18 inches $\$ 3.00$

18 to 21 incles.... 3.51

21 to 30 inches.

.00

Rhodedendrom Calawbiense

Fo-6 le 8 foet. Vore compact than the above rosy parple blomu in Jume.

121015 inches..... \$2.25 $\$ 2100 \quad \$ 200.00$

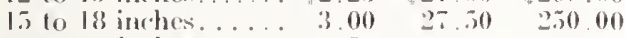

18 to 21 inches.... $3.50 \quad 32.50 \quad 300.00$

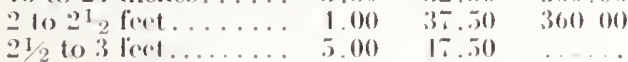

$5 \div 00$

Catawbiense rompantal

Denso, low compated form of abous

12 to 15 inches $\quad 52.5 \quad 52.00 \quad 82.500$

15 to 18 inches.... $3.50 \quad 32.50 \quad 300.00$

18 to 2.1 inches.... $1.50 \quad 40.00$

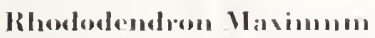

Fh -8 to 10 feet. Hose blem in Jume and fuly 15 to 18 inches. . . . \$2.00 $\$ 17.50 \$ 150.00$ 18 to 21 inches. . . . $20.50 \quad 2.50 \quad 200.00$

2 to 3 feet

3 to I feet

$\begin{array}{ll}2.50 & 22.50 \\ 3.50 & 32.50 \\ 5.00 & 17.50\end{array}$

MOLNTIIN IAITIEI.

(Kalmial Lallifolia)

Fl -5 to 8 feet. Shapony bush corred with white to pink lotom in June--attractive luads in Nay

121015 inclaes.... \$ \$ $1.2 .5810 .00 \$ 90.00$ 151018 inches..... $1.50 \quad 11.00 \quad 12500$

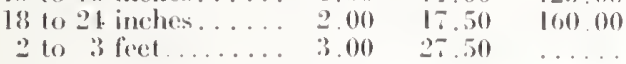

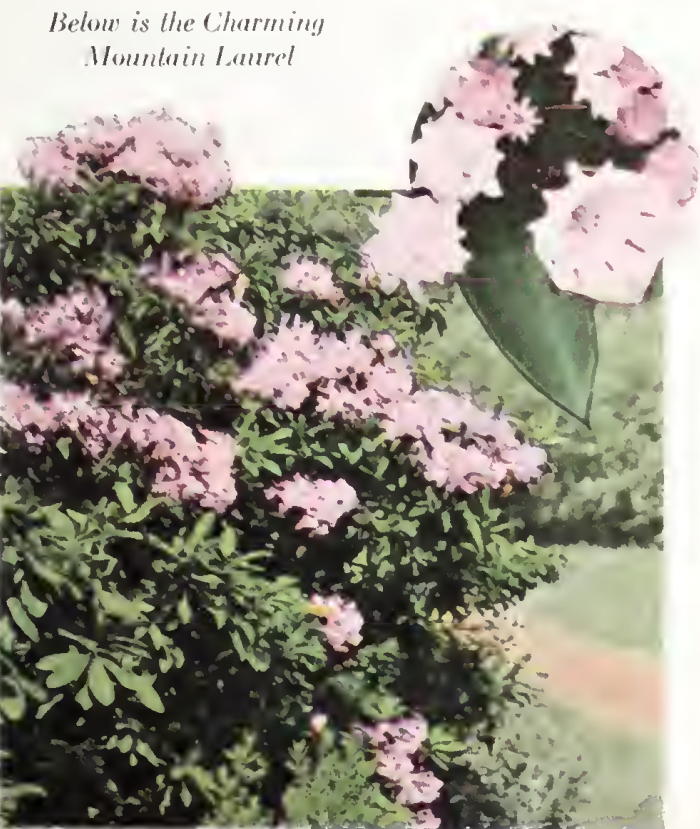

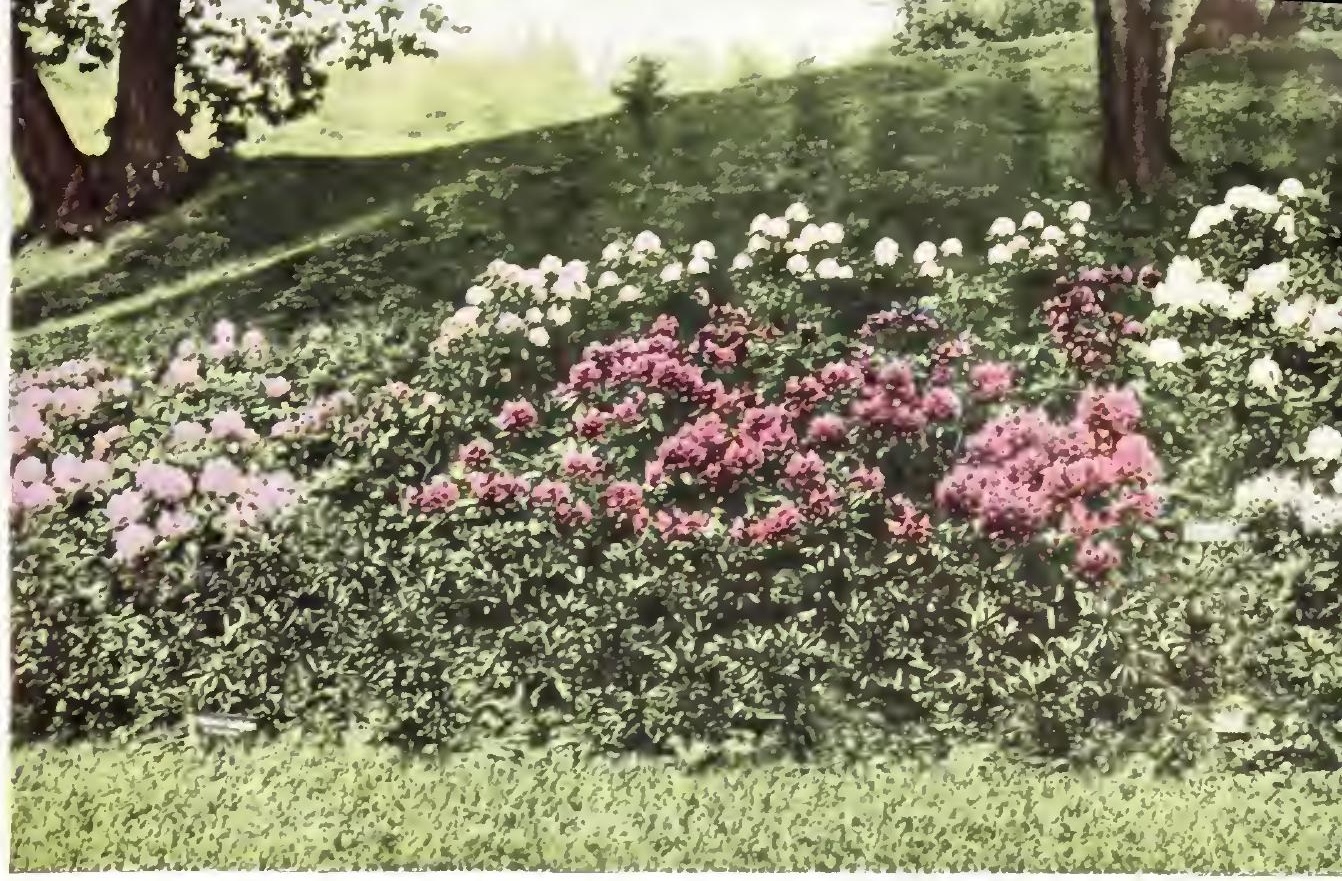

HARI)Y II YBRII)

\section{RIODOIENIRONS}

The 11 briels arre noted for lla beant, ricduew and larese size of their flowers, and their variet? of color. For these reasons they add grealty to the attractiveness of any Rhodesterdron planting. The phants priced betow are well shaped an ath flower buds, they are now in the open tich and adsolutety larely. They will be dha wilh line ball of litrous roots tor saffe tramplanting.

Imphion Clato pink with white ese, large 1)

Calawbion- Ilbum Il hite, line foliage

Callawbionse (Crandiflormon-1)ark

Mr. C. S. Sitrgent Derep rose shating to

Romonn filewans - iedear rose, compact

Titac, rompart, line. 1.2 to 18 indtes, B. A B. $8500 \$ 1.3 .00 \$ 100.00$ 13 to 21 inches, B. A B. 75070.00 60 60.00

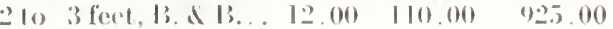
vear olds, grafted

about le inclies high

latterl.
Pre.. Lincoln - Lilac pirk, with brown cyc.

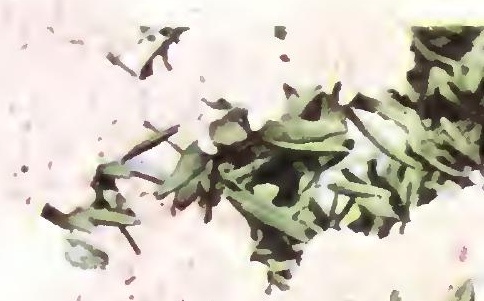

portiant fiil (st) or-

dinary garden soil. Ribododendronswitl shereed provided arid condition exof iml1 or stads ' serenre acidit! there are man methol. I mulcli of leaters at plied arey year and two or three incher derop, if the saw dhest be wetl rotted, is also ex cellent. I lazer of up placed orer the soil i. the millural "at effecting the result

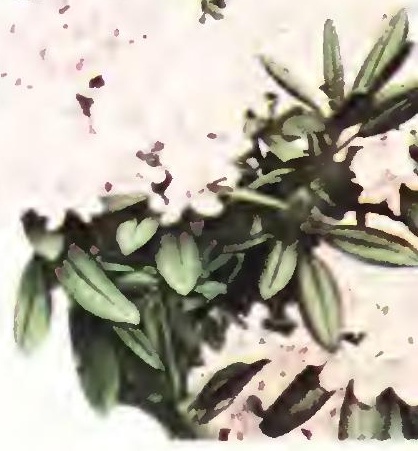

Floners of Lhodo. Warimun

\section{Native Mountain Laurel and Rhododendron in Carlots}

fior years we have specializerl in these fine evergreen shrubs. We offer some extremely lon prices for collected Rhododenthon Waximmm and halmia lati folia (Momutain lanel). The plants are (lug with a groed hall and pached in the car carefully for delivers in good condition. Strong clumps with several hanches. Fine for mass plantiurg. Carloads only. Freight extra from nearbs p'ennsylymia.

Rhododendron Maximum or Kalunia Iantifolia

SINGIE IOCK

\begin{tabular}{|c|c|c|c|}
\hline Sine & $\begin{array}{c}\text { Vumber of } \\
\text { Plants }\end{array}$ & $\begin{array}{c}\text { Tolal } \\
\text { Cost }\end{array}$ & $\begin{array}{c}\text { Cost } \\
\text { Each }\end{array}$ \\
\hline $2-3^{\prime}$ & 200 & $\$ 115.00$ & $7212 \mathrm{c}$ \\
\hline $3-1^{\prime}$ & 150 & 115.00 & $97 \mathrm{c}$ \\
\hline $2-3^{\prime}$ & 100 & 290.00 & $-212 \mathrm{C}$ \\
\hline $3-1^{\prime}$ & 300 & 290.00 & $97 \mathrm{C}$ \\
\hline
\end{tabular}

Issorted cars at proportionate prices. 


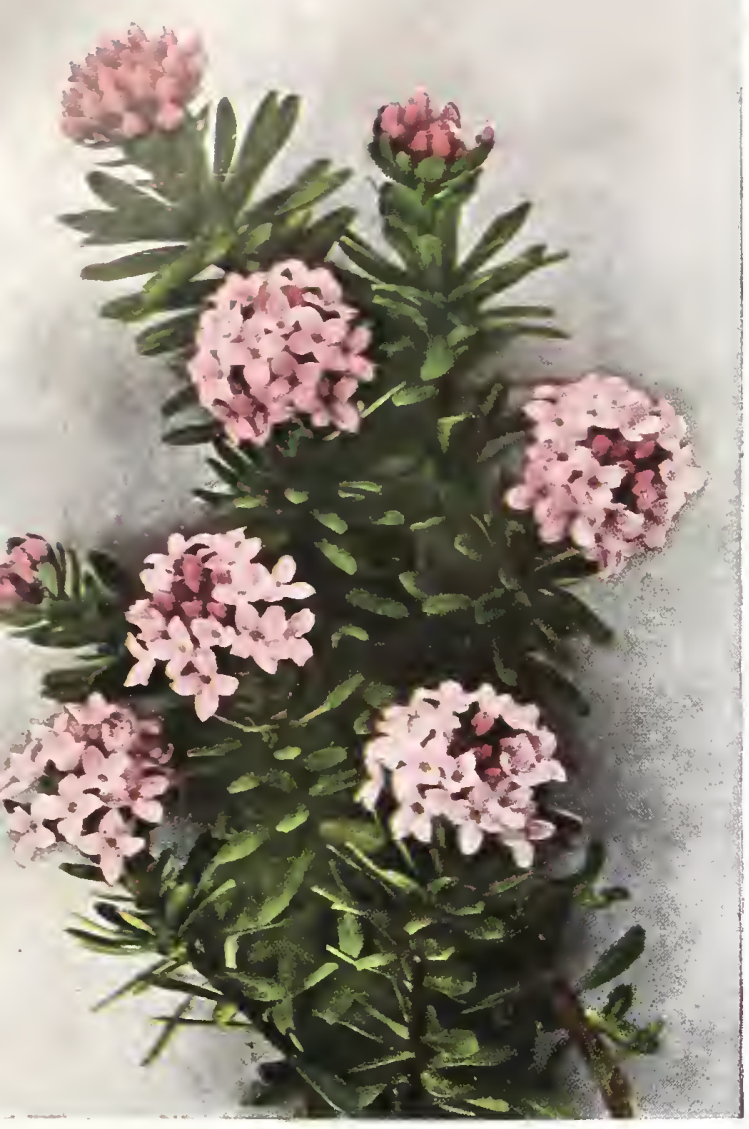

$\mathrm{A}^{\mathrm{T}}$ the left is a life-size color photograph. But it cannot tell the beauty of massed A blossom in May and again in September - it cannot portray the delicious fragrance that makes these plants a delight to own. To be coldly scientific:-it is thoroughly hardy in our area; entirely evergreen; fragrant; grows to a height of about 12 or 15 inches and spreads to twice that in width; dense-growing and compact; thrives in any good soil, but much prefers a sunny location.

Most Daphne cneorum offered in this country does not bloom intermittently in the Summer. We offer a special type. A dozen of them in a group will have at least some flowers every week of the Summer between May and frost.

\section{PRICES}

$\begin{array}{rcrr} & (\text { Each }) & (10) & (100) \\ 6 \text { to } 9 \text { inches spread. } & \ldots & \$ 5.00 & \$ 45.00 \\ 9 \text { to } 12 \text { inches spread. } & \ldots & 7.50 & 65.00 \\ 12 \text { to } 15 \text { inches spread. } \$ 1.25 & 11.00 & 100.00 \\ 15 \text { to } 18 \text { inches spread. } & 1.75 & 16.50 & 150.00 \\ 18 \text { to } 24 \text { inches spread. } & 2.25 & 21.50 & 200.00\end{array}$

\section{DAPHNE AS A BORDER PLAN'T}

For low borders marking the edges of perennial or rose plantings, what possible finer plant could be suggested? Plant them a foot apart in full sunlight and you have bloom all summer long and a firm evergreen outline during the cold months. Also idcal for edging walks, or paths.
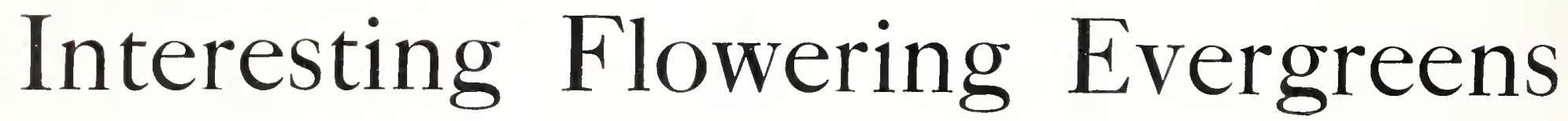

Beauty of flower plus an evergreen foliage is a combination impossible to ignore. No planting can be complete without some of the varieties listed.

Abclia (A. Grandiflora) (Arbutus Bush)

AEHK - 5 feet. White bell-shaped blooms in profusion over a period of about eleven weeksJune to September. Leaves rich bronzc in Winter. North of New York this is not entircly evcrgreen, though hardy.

\begin{tabular}{rrrr} 
& (Each) & \multicolumn{1}{c}{$(10)$} & $(100)$ \\
18 to 24 inches....... & $\$ .60$ & $\$ 4.00$ & $\$ 35.00$ \\
2 to 3 feet, Spccial.. & .75 & 6.00 & 50.00
\end{tabular}
B. \& B., 5c per plant extra.

Buxus Suffruticosa (Box Edging)

EGIK-3 to 4 feet. Excellent border for garden paths, etc. Very slow growing.

1. to 6 inches, bushy. . . \$ \$ $\$ 2.00 \$ 18.00$

6 to 8 inches, bushy. $\$ .50 \quad 4.00 \quad 32.00$

8 to 10 inches, bushy . $\quad .90 \quad 7.50 \quad 52.50$

10 to 12 inches, bushy. $\quad 1.75 \quad 15.00 \quad 120.00$

No less than 50 at the 100 rate.

Buxus Sempervirens (True Box)

EGIK - 10 to 15 fect. Slow growing, stauds shearing well, used in formal plantings.

8 to 10 inches, bushy. . \$ \$ $\$ 4.00 \$ 35.00$ 10 to 12 inches, bushy . $\ldots . \quad 5.50 \quad 50.00$ 12 to 15 inches, bushy. $\ldots .7 .50 \quad 70.00$ 15 to 18 inches, bushy. $\$ 1.50 \quad 11.00 \quad 90.00$ 25 at the 100 rate.

Cotoncaster llorizontalis (Rock Coloneaster) EGI-12 to 18 inches. Small shiny leaves, bright red berries, low sprcading habit.

12 inch spread, from 4

inch pots........\$ $.75 \quad \$ 6.50 \quad \$ 60.00$ 15 to 18 inches..... $\quad .90 \quad 7.50 \quad 70.00$

Inkberry (I. Glabra)

EGK - 5 feet. Yellow bloum in June and showy black berries in Winter

15 to 18 inches.....\$ $\$ 80 \$ \$ 6.00 \$ \$ 40.00$ 18 to 24 inches..... $1.00 \quad 7.50 \quad 60.00$
Japancse Holly (I. Crenata)

EG.J-18 feet. A splendid cvergreen slirub with black berries and small densc foliage. Not nearly well enough known.

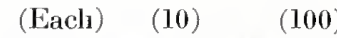

15 to 18 inches...... $1.50 \quad 12.00 \quad 105.00$

18 to 24 inches..... $2.00 \quad 16.00 \quad \ldots \ldots$.

Ilex opaca (American Ifolly)

FGK-8 to 15 feet. Yellow flowers in June and scarlet berries in Winter.

18 to 24 inches. . . . $\$ 2.00 \quad \$ 16.00 \quad \$ 120.00$ 2 to 3 feet....... $3.00 \quad 25.00 \quad 200.00$

3 to 4 feet....... $4.00 \quad 35.00 \quad 300.00$

Leucothoc Catesbaei (Drooping Leucothoe)

EHK -3 to 4 feet. White flowers in May, graccfully arching branches, fine for shady places. 12 to 18 inches.....\$ \$1.00\$8.00\$80.00 18 to 24 inches..... $1.25 \quad 10.00 \quad 100.00$

Pyracantha Coceinea Lalandi (Leland's Firethorn)

EGJ -8 to 10 feet. Brilliant orange-red berries lasting until January, hardy in New England in sheltered positions.

18 to 21 inches, 1 -in.

$\begin{array}{rrrr}\text { pots.......... } & \$ 1.50 & \$ 10.00 & \$ 85.00 \\ 3 \text { to } 4 \text { feet. . . . . } & 2.00 & 15.00 & 100.00 \\ 4 \text { to } 5 \text { feet. . . . . } & 2.25 & 17.00 & 120.00\end{array}$

$\begin{array}{llll}2.95 & 17.00 & 120.00\end{array}$

Lily-of-the-Valley Shrub (Andromeda floribunda)

This dwarf cvergreen shrub is a sight to behold in early Spring when it is covered with small spikes of delicate white flowers-very closely resembling the Lily-of-the-Valley.

12 to 15 inches.....\$2.00 \$17.50

15 to 18 inches..... $2.50 \quad 22.50 \quad \$ 100.00$ 18 to 24 inches.... $3.00 \quad 28.00 \quad 125.00$

PACHYSANDKA
(Living Carpet)
A dense mat six inches high, the Pachy-
sandra is indispensable where shade is too
heavy to grow a good lawn. Plant close to-
gether for best results. It requires abso-
lutely no attention.
2 year............ $\$ 12.00 \quad \$ 95.00$
$(25$ or more at the rate per 100$)$

Euonymus Radicans (Winlcrereeper)

Evergreen self-clinging vine, excellent for walk, under planting 15 to 20 feet.

(10) (100)

18 to 21 inches........... \$4.50 \$20.00

Hcdcra Helix (English Ivy)

Evergreen, very hardy, excellent for shady and exposed positions where it thrives best. 25 to 50 feet.

Strong plants from 3 inch pots. . $\$ 1.50 \$ \$ 10.00$

Lonicera Japonica Halliana (Hall's Jap.

Ioneysuckle)

Semi-evergreen, very fragrant, quick growing and very hardy, 15 to 20 feet. Excellent cover for walls and fences.

2 year strong plants.........\$1.00 \$16.00

1 year transplants $(\$ 40.00$ per

thousand)..

Vinca Minor (Myrtle)

Trailing evergreen plant good in partial shade.

Blue flowers in May.

Strong clumps $(\$ 65.00$ per

thousand).

$\$ 8.00$ 


\section{New and Rare Flowering Shrubs}

W E have attempted on these pages to pick the best. Occasionally old favorites remain unbeatable, but in the main the great advances in Horticulture have made possible new and improved varieties in every direction. Then, loo, there is no arguing about taste. Our selection might not be another's. We are in a position to quote upon and furnish in splendid shape most of the shrubs conmonly grown in I'nited States. We will gladly quote prices upon request. Massed in borders or as single specimens these charming shrubs provide colorful and fragrant bloom more easily and abundantly than any other form of vegetable life. They are inexpensive and yet true aristocrats in every sense of the word. They may be planted with impunity in any soil and almost any position. They require no care except a judicious pruning once a year, when they are through blooming.

\section{ALTHEI (Rose-of-Sharon)}

This old favorite is of never-failing beauty and usefulness, for it blooms in late. July and Iugust when few other flowers are available. We offer the eolors: Doulble P'ink, Doulble Red and Double Wlite.

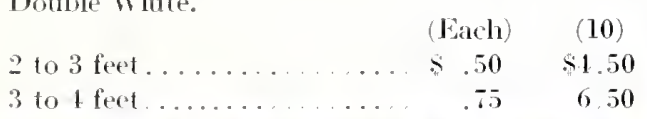

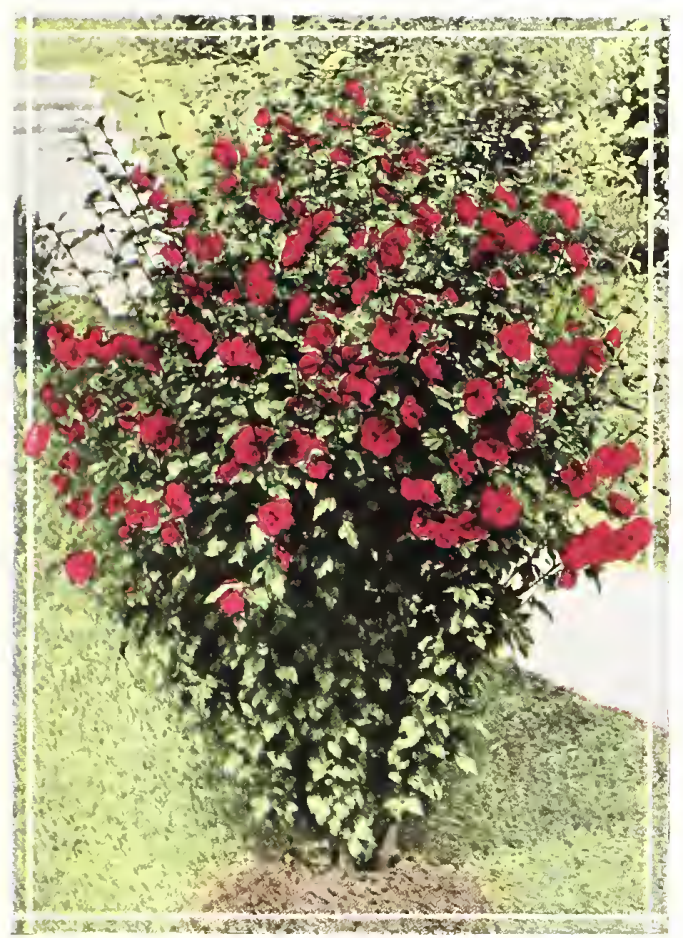

1thea or Rose-of-Sharon

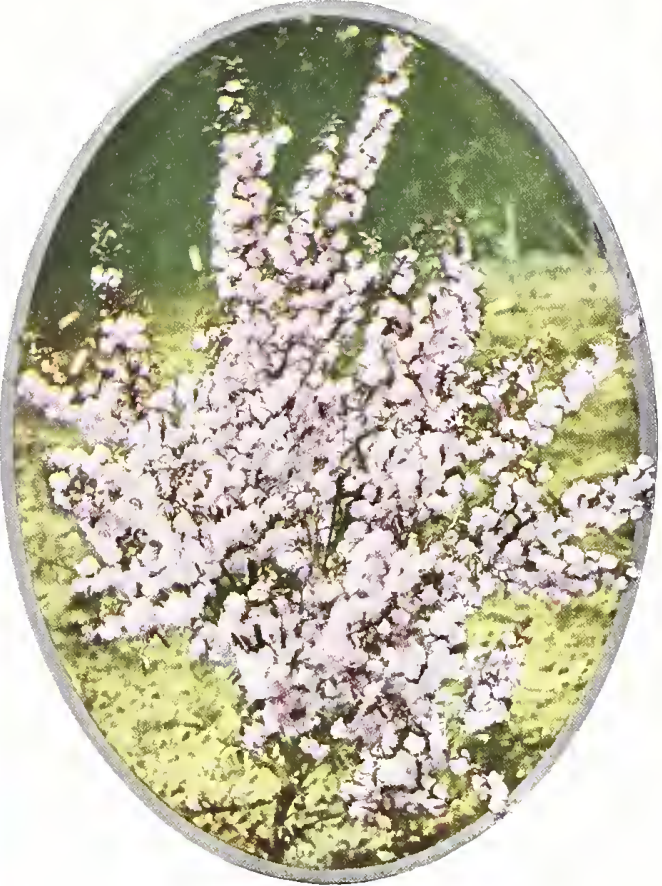

\section{FLOWERING ALMOND}

(Prunus glandulosus rosea)

One of the eharming early-flowering sliruls producing rose-colored flowers in great profusion. There is a whitc-flowered variety, which we offer at the same prices. The pink is pictured above.

\begin{tabular}{rrrr}
$11 / 2$ to 2 feet........ & (Eaeh) & \multicolumn{1}{c}{$(10)$} & \multicolumn{1}{c}{$(100)$} \\
2 to 3 feet........ & $\$ 5.00$ & $\$ 10.00$ \\
3 to 4 feet ........ & .75 & 6.50 & 50.00 \\
\end{tabular}

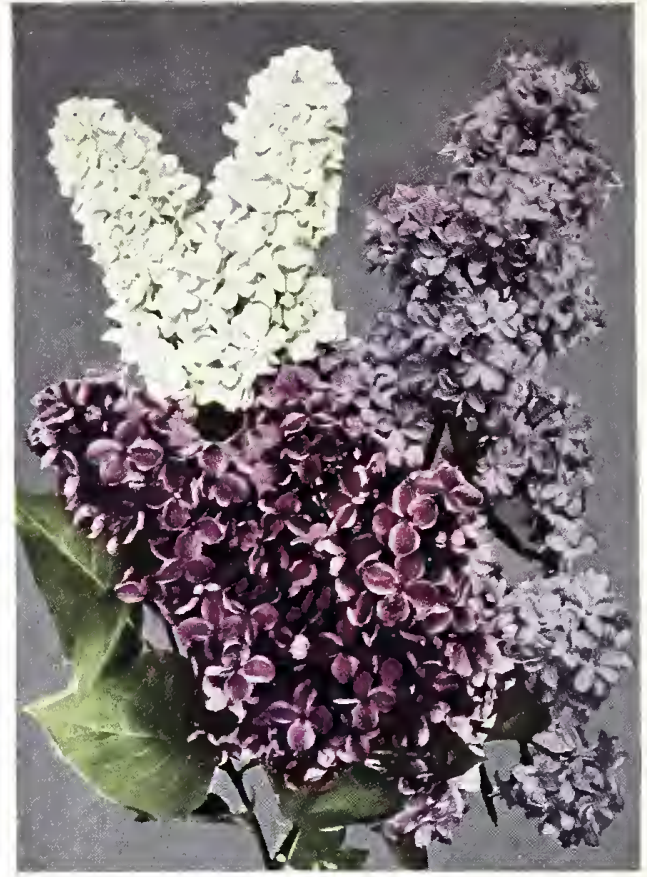

\section{HYBRID LILACS}

These beaut iful Lilacs are adlapted to large or small lawns. They require very little care and attcntion and can be depended upon each year for a profusion of colorful, fragrant panicles of bloom. The varieties we oller are hybrid sorts, possessing all the charm of the old-fashioned Lilacs and present a range of colors from white to richest purple.

\section{DOUBLE FLOWERED}

\begin{tabular}{|c|c|c|}
\hline $\begin{array}{l}\text { Mphonse Lavallee, } \\
\text { Belle de Vancy. }\end{array}$ & $\begin{array}{l}\text { Light Blue } \\
\text { Satin-Pink }\end{array}$ & \\
\hline Maillot. & Pinkish-Lilac & \\
\hline Doyen Keteleer, & Light Pink & \\
\hline Marliensis pallida, & Reddish-l'urp & urole \\
\hline Ume. Casinir P'erier, & White & \\
\hline Mme. Lemoine, & White & \\
\hline & White & \\
\hline President Grevy, Large, & Blue & \\
\hline & Light Lilac & \\
\hline Ville de Troyes, & Dark Purple & (1) \\
\hline & $50 \$ 1.50$ & \\
\hline & 600 & \\
\hline & $85 \quad 7.50$ & \\
\hline
\end{tabular}

\section{The Barberries (Berberis)}

Brilliant red berries on black branches in Winter, the Barberries present striking effects and are useful in evergreen groups. Nany species of Barberry are under quarantine restriction, but the Japanese Barberries, offered here, are absolutely free from insect pests and diseases. They are cffective as hedges, when they sliould be planted about one foot apart, but informal groups and specimens are entirely charning, as well. They will thrive under the pruning shears, but left alone tend to make shapcly low buslies ln themselves.

\section{THE JAPANESE BARBERRY}

Japancese Batbery (B3, Thunbergi)

The popular and well-known hedge barberry. Said to be the most valuahle single shrub in cultivation.

12 to 18 inehes.

18 to 21 inche

2 to 3 feet

\section{NEW REDLEAVED} BARBERR Y

Redleaf Barberry (13. Thunbergi atropurpurea)

Leaves are purplish red all Summer, a unique Leaves are purplish red all $\mathrm{S}$ note in the foliage scliene. New.
note

12 to 16 inches

18 to 24 inehes.

2 to 3 feet.
$\$ 2.75$

6.50
$(100)$ $\$ 25.00$
10.00 60.00

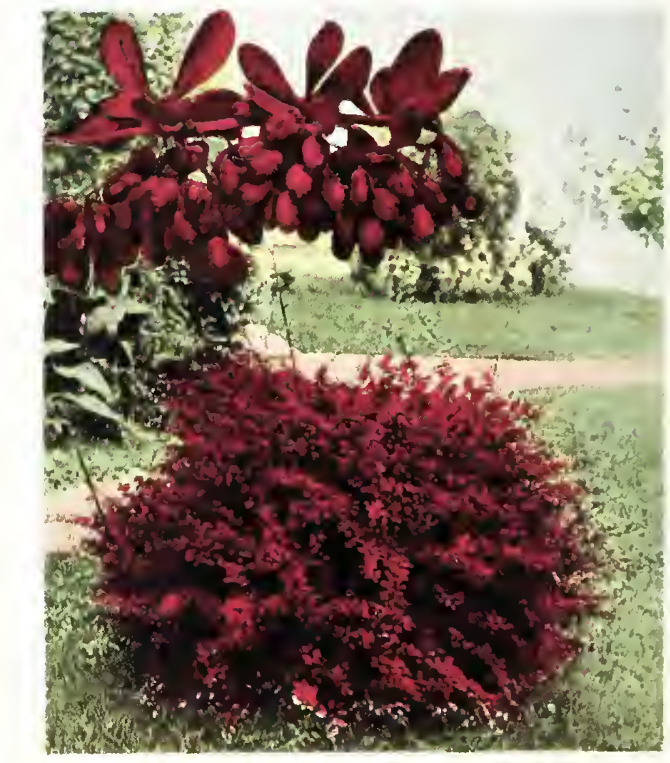

The New Redleaved Japanese Barberry 


\section{Peonies of Gorgeous Beauty}

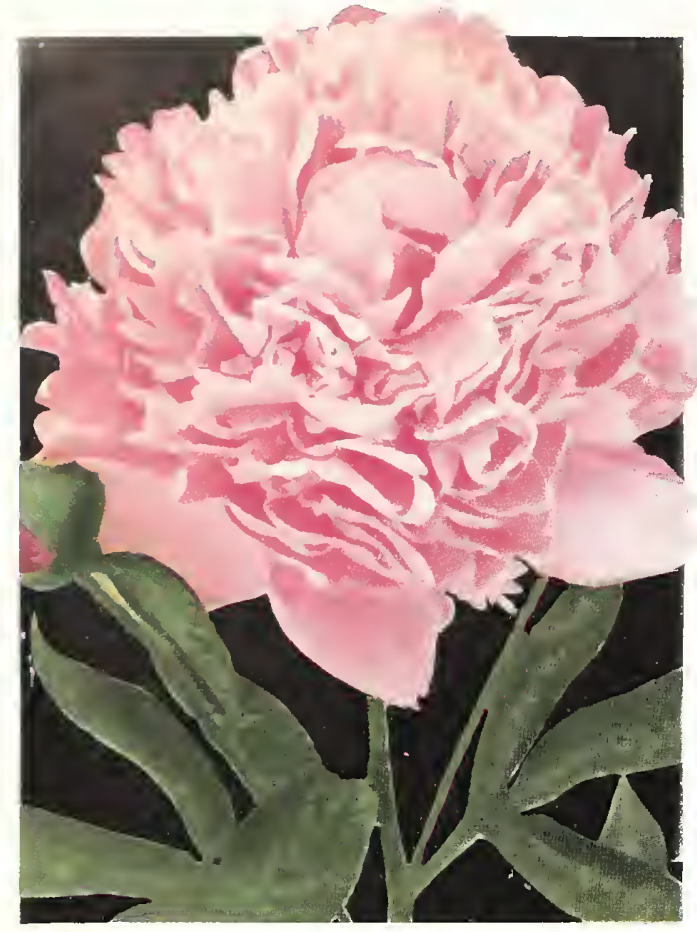

Peony Sarah Bernhardl

TOTHING in our northern gardens can provide such a wonderful show of bloom as the Peony. The range of color is enormous. There are varieties blooming early and late, making a wide range of blooming periods. Peonies are coarse feeders and do best in heavily enriched soils. The following are a few selected for value in the landscape.

Baroncss Sehroeder

Flesh color, changing quickly to white; creamy center................\$2.00 each

\section{Delachii}

Dazzling red, full double.......\$1.00 each

Dne de Wellington

Bomb type. Large flower of good form. White guard petals with sulphur center. .....50 each Edulis Superba

Mauve pink; large (early)......75c each Felix Crousse

Brilliant red with flame center. . . \$1.00 cach

Festive Maxima

Pure, waxy white with occasional flecks of crimson on the central petals........5c cach Grandiflora Rosca

Rosy pink.

$.50 \mathrm{c}$ each

\section{I.a Tulipe}

Large lilac-white, outer petals striped crimson. \$1.00 each
Marechal Valliant

Large globes of light red shaded mauve (late)...............\$1.00 each

Mons. Jules Elic

Medium pink.

Officinalis Rubra

Dark red; fragrant. Very early. . .\$1.00 each

\section{Purpurea}

Brilliant dark purple.........50 each

Quecn Victoria

Pure white.

Rocm Van Boskoop

Flesh white. $.50 \mathrm{c} \mathrm{each}$

Sarah Bernhardt

One of the strongest growers. Flowers are of remarkable size, full and double and of unusual perfection of form. 'The color is accurately portrayed in the color photograph at the left. This variety should be in every collection. .\$2.00 each
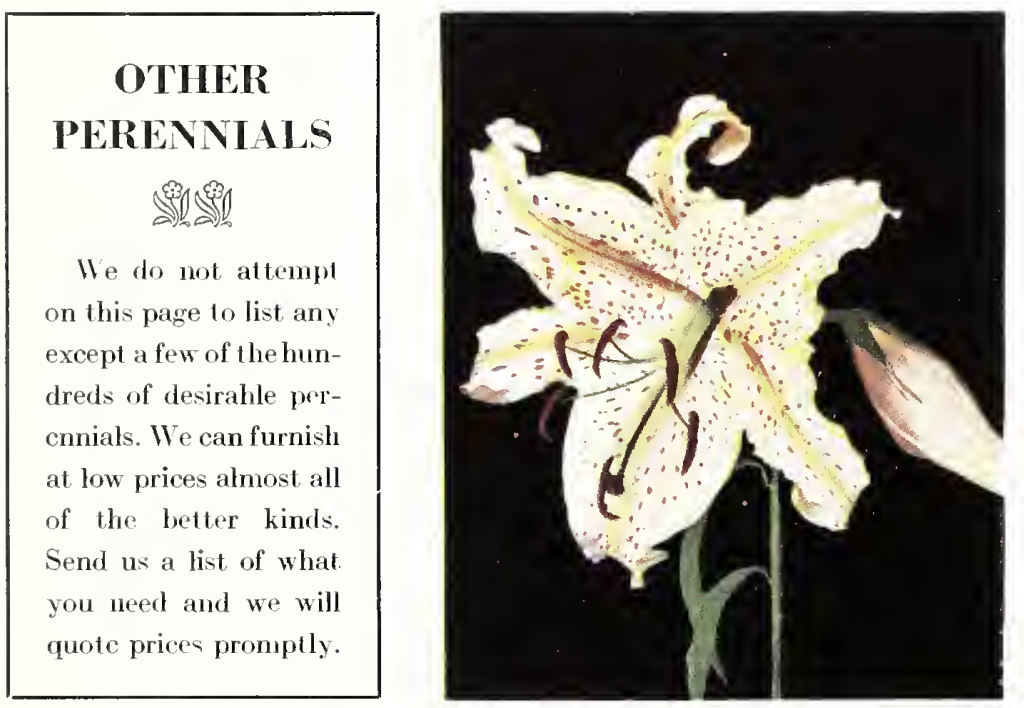

Lily Auratum

\section{EXQUISITE JAPANESE IRIS}

All the colors of the rainhow seem to have been gathered together in them in the most fascinating comhinations. The great size of the flowers is noteworthy, it being not at all unusual to have blooms 6 to 8 inches across.

$$
35 \mathrm{c} \text { each; } \$ 3.50 \text { per dozen }
$$

Astarte-Dark violet.

Gold Bonnd-Pure white; yellow markings.

Hercule-Clear lilac-hlue.

Helen-Van-Scibolt - Reddish, veined white.

Iphigenie-Coloring deep Chinese lilac.

Mahogany-Large; mahogany red; late.

Neptune single; mahogany red.

Norma-Deep purple.
Orion-Soft lilac; blotched white.

Oniga-Shima - Violet-purple: golden center.

Purple and Cold-Violetpurple.

Uchiu-Blue with golden center, and whitc.

Vase-Banri-White, veined blue.

Yedo-Jaman-Royal blue.

III virieties donble, cxecpt as noted.

\section{LILIES}

Wc have pickert two varieties illustrated on this page. Both are beyond reproach. They bloom in late Spring and Summer.

Lilinm Amatum at the left has deliciousty fragrant flowers up to 10 inches across.

\section{$\$ 8.00$ per dozen}

Speciosum rubrum also from Japan has fragrant drooping blooms four inches long.

$\$ 9.00$ per dozen

(We offer extra large bulbs.)

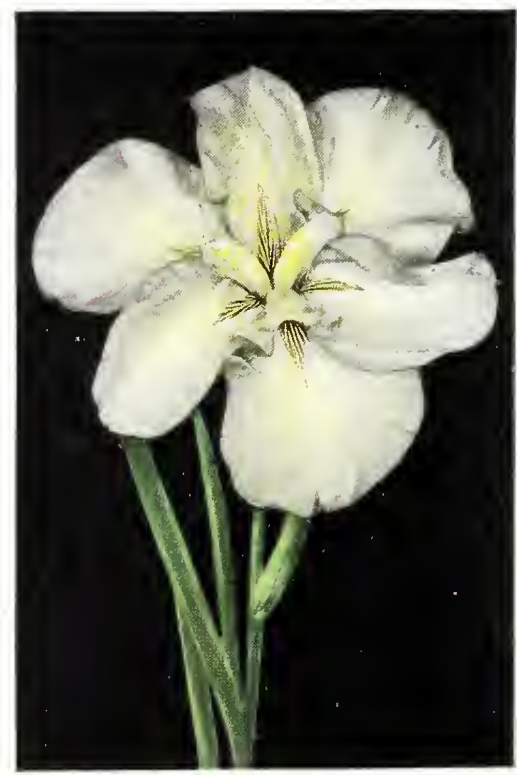

Japanese Iris

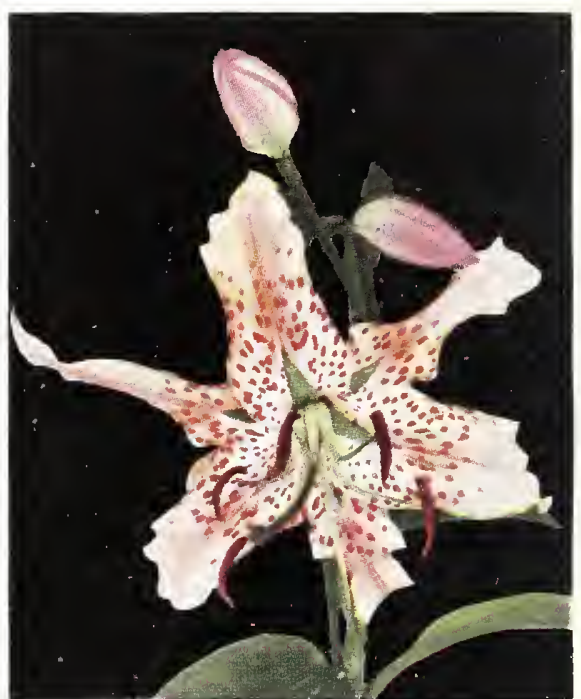

Lily Speciosum rubrum

\section{O'THER IRIS}

German Iris

In extended variety at low prices. Write for quotation on your needs.

Iris pumila hybrida

Caerulea-early light blue. Cyanea-Royal purple.

$\$ 4.00$ per doz.; $\$ 30.00$ per 100 Iris Pallida Dalmatica

$\$ 4.00$ per doz.; $\$ 30.00$ per 100

Iris Cristata

$\$ 3.00$ per doz.; $\$ 20.00$ per 100

Iris Pseudacorns

$\$ 3.00$ per doz.; $\$ 20.00$ per 100

Iris Sibcrica Orientalis

$\$ 3.00$ per doz.; $\$ 20.00$ per 100

We are in a position to quote very special prices on good plants of the above and other types by the thousand. 


\section{Reforestation}

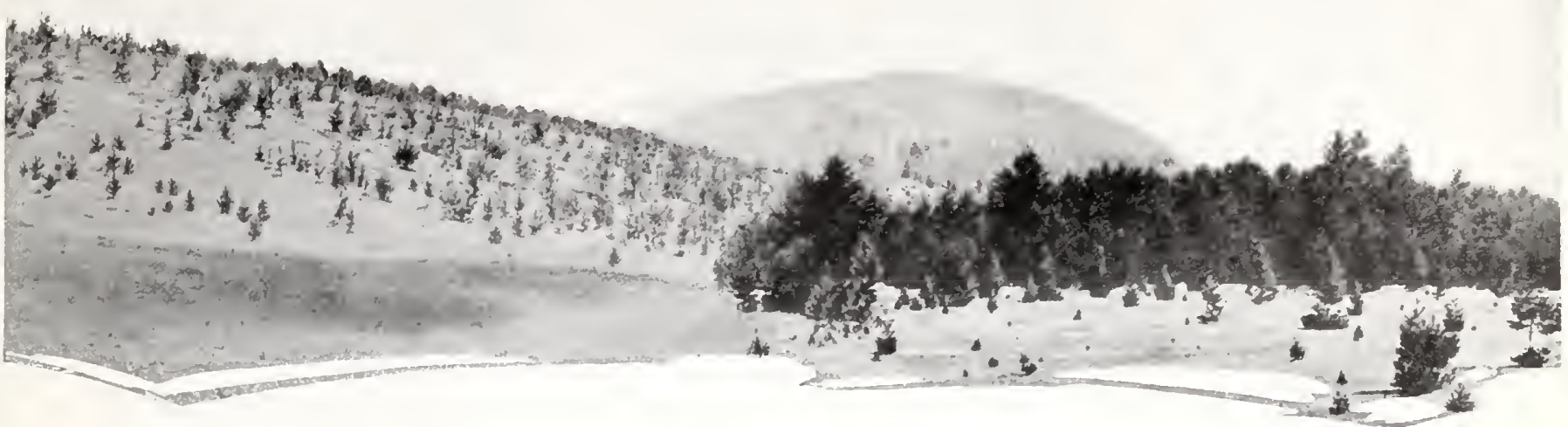

$\mathrm{T}$

THE surprising prodigality heretofore prevaling in forest destruction all over the enuntry is at last arousing publie opinion.

There is a rapidly growing and wide-spread interest now being taken both by private planters, Vational, State and Mlunicipal

Departments towart restoring as far as possible what has been irretrievably lost, due to the suicidal policy and wanton waste of our forests and the consequent depletion of our national timber resources.

Supplying all young stock in quantity for reforesting and for mursery planting on the nost favorable terms is one of the important and well-known features of the KELSEY VIRSERI SERI ICF. That these facilities are more and more appreciated by past and prospective patrons is shown in our constantly increasing business.

It is, therefore, advantageous, especially where material quantities are required, to get in touch wilh us before making purchases.

A complete list of young seedlings and transplants will be found on the (ireen Folder pasted inside the back cover. But it by no means prices all the stock we have to offer. And in large quantilies we are prepared to make very special low prices. Write us for prompt quotation on your needs.

\section{PLAN'TING COS'TS}

The economic side of the phanting of yomg t rees is, perhaps, net generally inderstood. A yearly income of 15 to 20 per cent on an invest ment in reforestation is wedl withiu the bounds of possibility if ordinary eare and intelligence are exercised. 'This invest ment would, of ceurse, loe a long-term one of 20 to 50 years.

The cost of planting is made up by reckoning the value of the land, the yearly taxes the cost of liabor in plintiug and the cost of the treps themselves. All these factors are varialde, except that the actual lador of planting should average about $\$ 12.00$ per acre. The number of trees per acre in a $6 \times 6$ foot planting is 1,200 , and in an average planting of line and Spruce these would cost for three year transplants $\$ 2.5$ to $\$ 3.5$ per acre. Seedlings would, of course, be much cheaper and more economical, but retuire tom much care on the average private estate where reforestation is purely a minor item and taken up as much for pleasure as for profit.

A typical cost loudget per acre might be as follows:

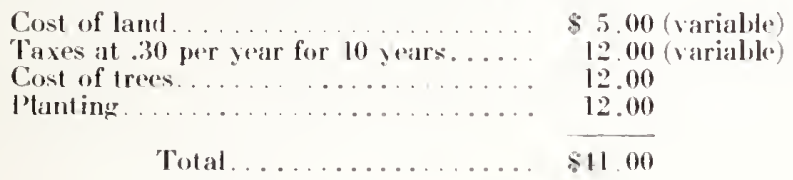

\section{PROFI'T FROM 'TREES}

As against this cost the timber at the end of thirty years-in Spruces Pines or Firs, should vield about 15,000 board feet at from $\$ 6$ per tluousand for Pine up to $\$ 12$ per thousand for Spruce and Fir, or $\$ 90.00$ to $\$ 180.00$ total income per acre. If cut for pulp-wood instend of lumber, the yield should be 30 to 15 cords per acre- at about $\$ 1.00$ per cord, or $\$ 120.00$ to $\$ 180.00$ ver aere.

At 10 years of age the board feet would range from 30 to 10 thousand feet per acre and the cords of pulp-wood also approximat ely double the figures for 30 years. For this reason 10 years is a much nore economical period to crop the timberland.

\section{CHRISTMAS TREE GROWING}

The phanting of 1 hite ant Norway Spruce and Douglas and Balsan fir for Christmas Trefe cutting is another phase of commercialized forestry which is profitable. This crop usually natures in ahout 12 years and when cut, leaves the timber-lot properly spaced for forest growing. One tree is planted bet ween each two permanent trees and requires no extra land; indeed it is an assistance to the young evergreen for the first ten vears to have the shade and shedter of a dense planting, which must, however, be cleared away in time, whether for Christ mis tree use or not, in order to maintain a six by six fuot space for permanent growth.

\section{BEST VARIETIES FOR SPECIAL SOILS

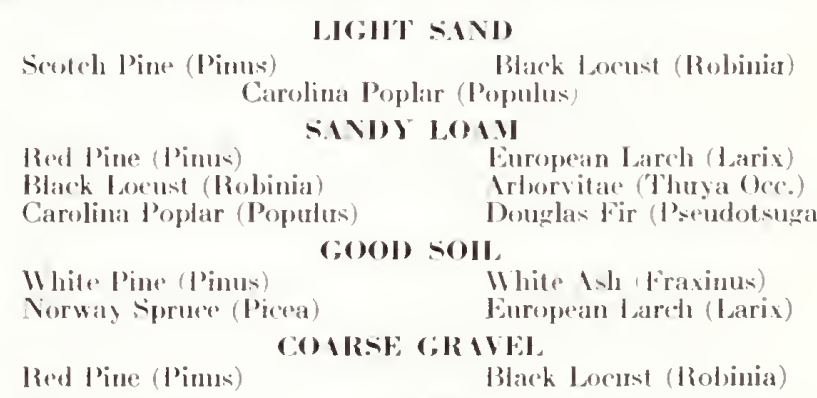

White l'ine (Piuns) I. () III

Vorway spruce (Picea)

II hita Isli (Fraxinus)

Carolina Poptar (Populus European Larch (Larix) Arlorvitae (Thuya)

Balkan Fir (Mhies) Irloorsitae (Thuya Occidentalis) Carolina Poplar (Populus)

\section{SOME INAZIYG PRICES}

By special arrangement we offer the entire production of a large mursery in II aine spectalicing in Feroreen seedliugs and small transplants for large forestry plantings. This stock is exeeptionally hardy on account of its Vorthern urigin. The prices are oflered with a view to enable targe areas to be reforested with numinum expenses.

3 rear seedlings $(3-0)$

3 vear transplants $(2-1)$

1 vear transplants (3-1)

White spruec (l'icca alla)

3 year seedlings $(3-0)$

1 year transplants $(3-1)$

$(1000)$

1100

I.). 00

5.25

1.5. 00

scoteh I'ine ('Truc Riga variely

3 year seedlings $(3-1)$

4 vear transplants $(3-1)$ o to 12 inches.

5.25

Red Pine (Pinus resinos:

2 year seedlings $(2-0)$

3 vear transplants (2-1)

(Special Prices on Large Quantilies)
8.00

11.00 


\section{Young Aristocrats}

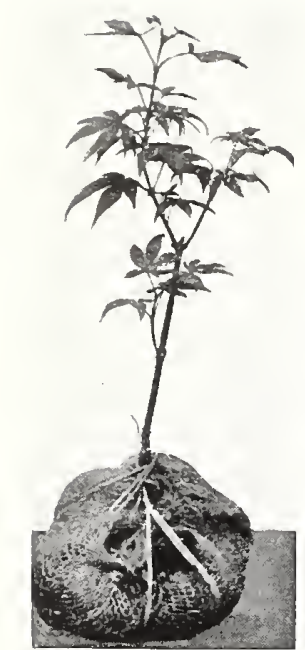

Redleaf Japanese Maple

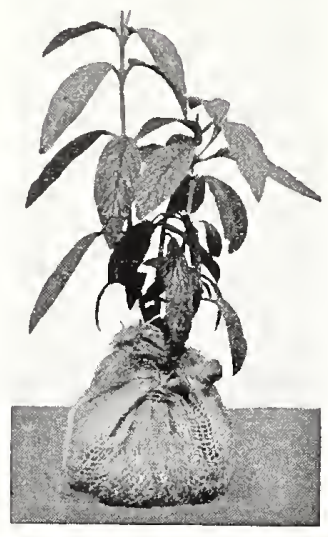

Viburnum Rhytidophyllum

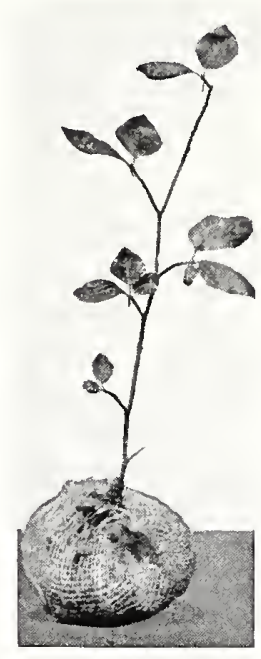

Purple Beech

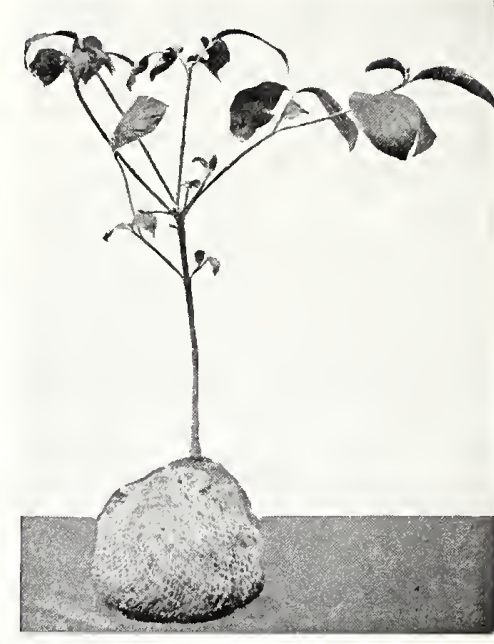

Redflowering Dogwood

Photographed on Long Island, August 1, 1931 - now ready to ship.

$\mathrm{U}$ NUSUAL and rare varieties ... true to name because they are grafted . . . easy to grow because they have already passed a season out-of-doors. Some Winter protection is desirable, but no other special treatment. Many of the sizes are offered Balled and Burlapped for still easier handling. Where so noted, please remember that Dutch burlap is used and can be planted without removing from the plant. This is an amazing opportunity to plant rare and delightful kinds at little cost.

\section{ACER (Maple)}

We offer two of the many excellent Japanese redleaved varieties. Larger sizes will be found on page 7 . The utmost care has been exercised, for there are many types of Bloodleaf Japanese Maple grown. Of these sub-varieties we selected the variety Osheri beni which is the one offered below.

A. palmatum atropurpureum (Redleaved Japanese Maple) (10) (100) 1 year, 10 to 15 in. B. \& B. . . . \$10.00\$90.00 A. purpureum disseetum (Cutleaved Red Japanese Maple)

1 year, 10 to 15 in. B. \& B... $12.50 \quad 95.00$

\section{CORNUS (Dogwood)}

C. florida rubra (Redflowered)

1 year, 12 to 18 in. B. \& B. $9.00 \quad 75.00$

\section{FAGUS (Beech)}

Here are true aristocrats. The grafts offered are true to type and strong. We call attention to the fact that the first Summer a young purple Beech is planted it cannot be expected to develop much color. That will come, like a meerschaum pipe, with the years.

F. Sylvatiea pendula (Weeping)

1 year, 12 to $18 \mathrm{in.} \mathrm{B. \& B.. \$ \$ 10.00 \$ 90.00}$

F. Sylv. heterophylla (Fernleaf)

1 year, 12 to 18 in. B. \& B. . $11.00 \quad 100.00$

F. Sylv. riversii (Purple Beeeh)

1 year, 12 to 18 in. B.\& B. . $10.00 \quad 90.00$

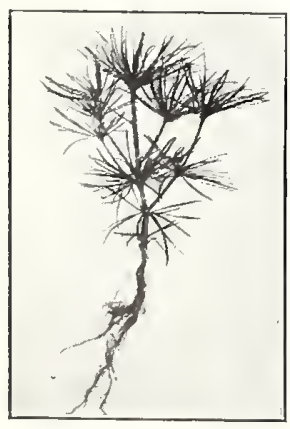

Sciadopilys 8 to $10 \mathrm{in.XX}$

These are the actual trees we offer - pholo Aug. 3, 1931
MAGNOLIA

\begin{tabular}{|c|c|}
\hline $\begin{array}{l}\text { M. Soulangeana } \\
1 \text { year, } 10 \text { to } 12 \text { in. B. \& B. . } \$ 12.50 \\
18 \text { to } 24 \text { in. B. \& B... } 30.00\end{array}$ & $\begin{array}{c}(100) \\
\$ 120.00 \\
250.00\end{array}$ \\
\hline $\begin{array}{l}\text { I. stellata } \\
1 \text { ycar, } 10 \text { to } 12 \text { in. B. \& B... } \\
\qquad 18 \text { to } 24 \text { in. B. \& B... }\end{array}$ & $\begin{array}{l}120.00 \\
360.00\end{array}$ \\
\hline $\begin{array}{l}\text { I. soulangeana nigra } \\
1 \text { year, } 10 \text { to } 12 \text { in. B. \& B... } 12.50\end{array}$ & 120.00 \\
\hline $\begin{array}{l}\text { V. Carlesi } \\
1 \text { year, } 8 \text { to } 12 \text { in. B. \& B. . . } \$ 10.00 \\
\text { V. Rhytidophyllum (Everareen) } \\
1 \text { year, } 12 \text { to } 15 \text { in. B. \& B.. } 9.00\end{array}$ & $\$ 90.00$ \\
\hline
\end{tabular}

BIOTA (Oriental Arborvitae) B. aurea nana (Golden Dwarf) $\ldots . \quad 70.00$
B. aurea conspieua....... $\ldots .$.

\section{CEDRUS (Cedar)}

C. Atlantiea glauea (Blue Atlas Cedar) 12 to 15in. B.\&B.21.00 160.00

\section{CUPRESSUS (Cypress)}

C. Triumph of Boskoop

1 year, 12 to 18 in. B. \& B. . $\quad 7.00$

60.00

\section{CR YPTOMERIA}

C. Lobbi

1 ycar, 10 to 12 in. B. \& B... 11.00
JUNIPERUS (Junipers)

J. Virginiana glauea J. Virg. Keteleri J.Virg. Cannarti J.elegantissina Lee J.Virg. Schotti J.ehinensis

1 year grafts, 10 in. . . . . . . . $\$ \$ 50.00$

\section{PICEA (Spruce)}

The grafted Spruce we offer represent nothing but well-proved varieties. The Blue Spruces are well-known. The Moorheim is a new variety although this is a matter of opinion. The Dwarf Spruce listed is a curious little mass of dense green. The needles are so small that the effect is of a toy-tree. It grows with utmost slowness and is useful for rock gardens.
Posteri (Koster Blue) (10) (100) 1 year, 8 to 10 in. B. \& B. . . \$13.50 \$120.00
P. Moorheimi (Moorheim Blue)
1 year, 7 to 10 in. B. \& B... $13.50 \quad 120.00$

\section{TSUGA (Hemlock)}

T. Can. Sargenti (Sargent Weeping)

1 year, 12 to 15 in. B. \& B. . $12.50 \quad 105.00$

Additional grafted varieties will be found in the green price-list at the right and still others gladly quoted on request. perhaps a little better in color than Koster's,

We have several other varieties available not listed on this page. Where a " 10 " rate is given, orders will be accepted for 5 or more. Or we will accept trial orders for ten trees of five different kinds - two of each-at the same prices. Otherwise, 25 of a kind is a mininum order.

\section{START YOUR OWN NURSERY}

The Green Price-List pasted inside the back cover is a list of young stock for transplanting and growing on. Two samples have been photographed and appear at the left, Sciadopitys and Taxus. This is the actual stock we have available to ship on orders received. Lining-out stock is not suitable for landscape planting, nor intended for that purpose. It will in a few years grow into specimen grades, however, and the prices are such that by planting now and waiting a few years it is possible to make quite extensive plantings at nominal cost. Particularly is this true this year-prices are as low as they will ever be-what a wonderful time to buy!

On the fourth page of the Green Price-List will be found some easy and simple rules and explanations regarding the planting and care of these little trees. 
NAME _..._BURLINGTON

ORIGINATED BY WITII

IMPORTED BY

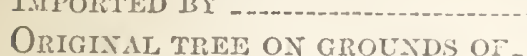

ParfevT A

Publication of xame

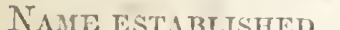

Original DESCRIPTIUN:
Synonym of
Group

Reported alive

Sipplimentuix descriptiox: 1. Tree is very easily grown, rapid grower, extremely hardy. Nut resembles the pecan.

Citatioxs: 1. Kelsey nursery service, New York, N. Y. Short guide...; 1932, p.4. 


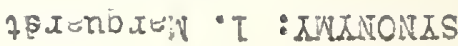


NAME -..Marquardt. Synonym of

ORIGIXATED BY WI'] Locality

1. BURLINGTOII

IITORTED BY From

- $\quad$ - n - -

Date

ORIGINAL TREI ON GROTYDS OE

Parentage

Pliblcatrox of Name

Name established ..

Group

Reported alive

Date..

Oiriginal descriptiox:

Stpplemextm descriptiox: 1. Tree is very easily grown, rapid grower, extremely hardy. Nut resembles the pecan.

Crtatioxs: 1. Kelsey nursery service, New York, N. Y. Short guide...; 1932, p. 4. 


\section{Evergreens for Lining-Out and Reforestation}

THE following lists are not complete. We can furnish many other kinds and in a greater range of sizes. If you do not see what you want, please write us for a special quotation. We sell 250 at the thousand rate and 50 at the hundred rate, except for seedlings under $\$ 25.00$ per thousand, where we cannot accept orders for less than 100 of a kind.

"S" Indicates seedlings not transplanted.

" $\mathrm{X}$ " Indicates each transplanting.

ABIES (Fir)

Balsamea (Balsam Fir)

1ts characteristic clean odor and stateIy appearance make this a desirable value as timber. Ideal evergreen for wet land. Popular variety for Christmas trees.

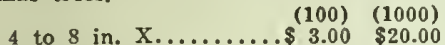

4 to 8 in. $X \ldots \ldots \ldots . . . . .33 .00 \quad \$ 20.00$

5 to 10 in. $X X \ldots \ldots . . . .65 .00 \quad 35.00$

brachyphilla (Nikko Fir) $4.00 \quad 30.00$

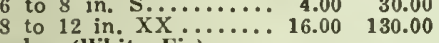

concolor (White Fir)

Dense silver blue foliage.

Finest Fir for ornamental effect.

4 to 6 in. X........... $5.00 \quad 35.00$

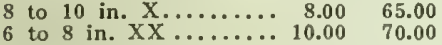

6
8 to 8 in. 12 in. XX......... $18.00 \quad 140.00$

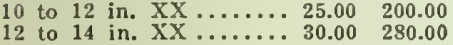

\section{THE DOUGLAS FIR}

(Pseudotsuga taxifolia)

One of the most beautiful conifers, yct

easy to grow and valuable also for

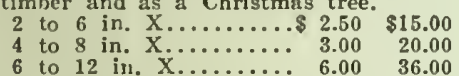

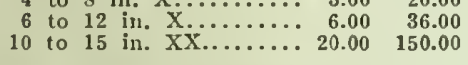

Nordmanni (Nordmann's Fir)

4 to 6 in. X.......... $15.00 \quad 130.00$

2 yr. S 8 to 12 in
Mariesi (Maries Fir)

Prices on request.
pcctinata (Silver Fir)

6 to 8 in. S......... $4.00 \quad 26.00$

$\begin{array}{llll}6 & \\ \text { eitchi (Veitch's Fir) } & & & \\ 6 & 4.00 & 4.00 & 26.00\end{array}$

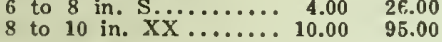

CEDRUS (True Cedar)

atlantica (Atlas Cedar)

Prices on request.

Prices on reque

libani (Ccdar of Lebanon)

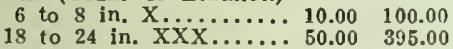

CRYP'TOMERIA (Japanese Cedar)

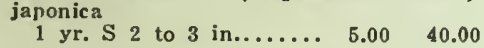

CUPRESSUS (True Cypress,

Northern Grown)

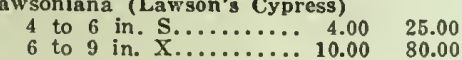

JUNIPERUS (Junipers)

Communis depressa (Common

Prostrate Juniper)

6 to 8 in. X......... $10.00 \quad 80.00$ 8 to 10 in. X............ $16.00 \quad 145.00$

6
6 to 8 in. X............ $12.00 \quad 112.00$

Communis depressa aurea

6 to 8 in. $X \ldots \ldots \ldots \ldots 12.00 \quad 112.00$

6 to 8 in. X.............. 12.00112 .00
Communis hibernica (Irish Juniper)
6 to 8 in. X......... $12.00 \quad 112.00$

6 to 8 in. $X \ldots \ldots \ldots \ldots 12.00 \quad 112.00$

Horizontalis douglasi

(Wrukegan Juniper)

6 to 8 in. X......... $16.00 \quad 145.00$ excelsa stricta (Spiny Greek Juniper) 4 to 6 in. X........ $14.00 \quad 120.00$

Chinensis Pfitzeriana (Pिitzer's Juniper)

Probably the finest of the

ornamental Junipers.
Feathery greenish - blue

\begin{tabular}{c}
4 to 6 in. $X \ldots \ldots \ldots \ldots 13.00 \quad 120.00$ \\
\hline
\end{tabular} 6 to 8 in. $\mathrm{X} \ldots \ldots \ldots \ldots \ldots \ldots+18.00 \quad 160.00$ $\begin{array}{r}8 \text { to } 10 \text { in. X......... } 24.00 \quad 175.00 \\ \hline \text { (Savin Juniper) }\end{array}$ 6 to 9 in. X........ $18.00 \quad 160.00$ Virginiana (Red Cedar) Northern 20.00 $\begin{array}{llll}1 & \text { yr. S.................... } & 20.00 \\ 6 & \text { to } 12 \text { in. S........ } & 80.00\end{array}$

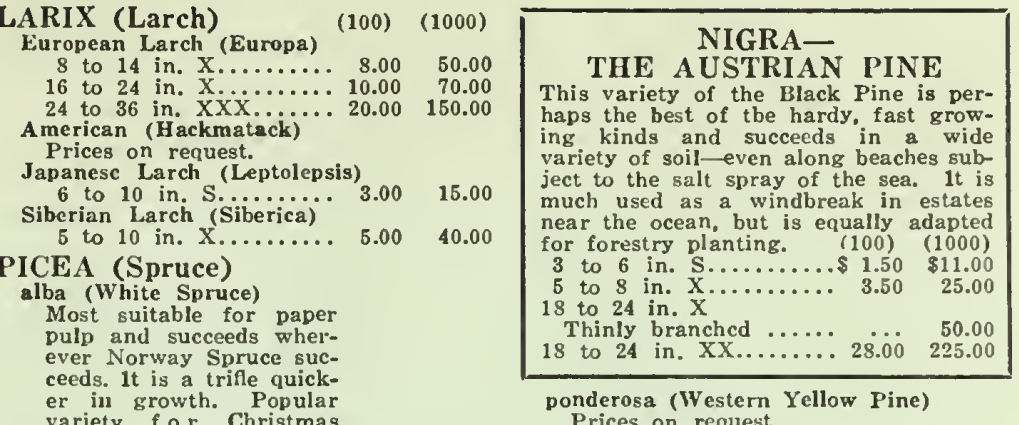

er in growth. Popular

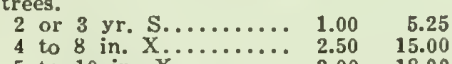

5 to 10 in. $X \ldots \ldots \ldots \ldots, \quad 3.00 \quad 18.00$

10 to 15 in. $X X X \ldots \ldots 12.00 \quad 90.00$

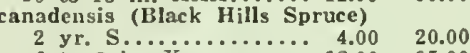

6 to 8 in. $\mathrm{X} . \ldots \ldots \ldots \ldots \ldots$
cuglcmanni (Englemann's Blue)

One of the finest of the

densces, and ranges from

bluish green to stecl blue

in color.

3 yr. S...

3 to 6 in. $\mathrm{X}$

$1.50 \quad 10.00$

\section{NORWAY SPRUCE}

(Picea excelsa)

This variety will thrive in dense shade and succeds in heavy damp soil. Hav-

ing a flat root system, it is suitable fo

shallow, rocky soils. The hardiest

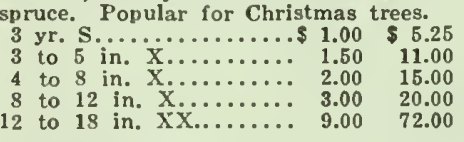

polita (Tigertail Spruce)

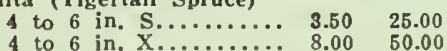
pungens (Colorado Blie Spruce)

This variety varies in

color from light blue to

light green. Unless stat-

ed "Selected Blue" our

stock runs from 30 to
$50 \%$ blue. In small sizes,

it is usually cheaper to

buy selected trees. Even

seed from the Koster blue

blue seedlings.

2
3

5 to 9 in. $x$

6 to 8 in. XX...

Borealis (Polar Spruce)

5 to 9 in. $X$.

4 to 6 in.

Oriental Spruce

4 to 6 in.

rubra (Red Spruce)

3 yr. $\mathrm{S} . . . .$.
3 to 6 in. $\mathrm{X} . \ldots$
4 to 8 in. $\mathrm{XX} .$.

NUS (Pine)

banksiana (Jack Pine)

6 to 10 in.

densifora (Jap. Red Pine)

Lighter foliage and more

spreading then the Aus

trian Pine, bu t a Is o

thrives in seashore plant-

ing. Un de $r$ s to c $k$ for

4 to 6 in. $S$ to 15 in. $X \ldots \ldots$

unghus (Mugho Pine) 4.00

3 yr. S.............. 2.00 11.00

3 to 5 in. $X \ldots \ldots \ldots . .3 .50 \quad 28.00$

4 to 6 in. $X$

6 to 8 in. $\mathrm{XX}$

$\begin{array}{rr}6.00 & 50.00 \\ 12.00 & 90.00\end{array}$

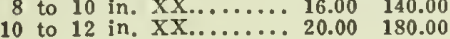

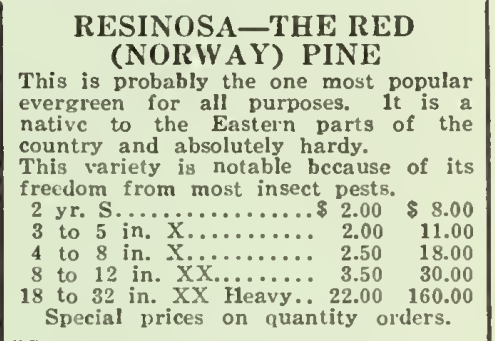

rigida (Pitch Pine)

4 to 6 in $\mathrm{X} . \ldots$.
strobus (White Pine)

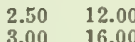

New York State only.

New England States only.

Penna. only.

sylvestris (Scotch Pine)

lence for poor soils-even

dry sand wastes can be

Scotch Pine.

8 to 12 in. $\mathrm{Y}$.

\subsection{0}

RIGA SCOTCH PINE

(Pinus sylvestris var. Rigensis)

This has long been known among for-

ordinary Scots Pine.

Where the type frows straggly and

with a crooked leader, the Riga variet

puts up a straight clean trunk.

12 to $18 \mathrm{in.}$

18 to 24 in. $X$

2.00
6.00
8.00

thunbergi (Jap. Black Pine)

12 to 16 in.

12 to 18 in. X......... $6.00 \quad 50.00$ RETINOSPORA

Japanese Cypress)

filifera

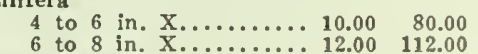

Glifera aurea

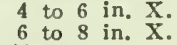

pisifera

to 6 in. $X$

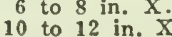

pisifera aurea

plumosa

4 to 6 in. $\mathrm{X}$.

10 to 12 in. $X$

4 to 6 in. $\mathrm{X}$

6 to 8 in. $\mathrm{X}$.

quarrosa veitchi

4 to 6 in. $\mathrm{X}$

6 to 8 in. $X$.
8 to 12 in. $X$.

obtusa

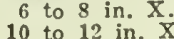

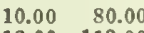

$12.00 \quad 112.00$

$10.00 \quad 60.00$

$12.00 \quad 75.00$

$\begin{array}{rr}10.00 & 80.00\end{array}$

$10.00 \quad 80.00$

$\begin{array}{ll}12.00 & 112.00 \\ 20.00 & 160.00\end{array}$

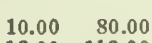

$12.00 \quad 112.00$

16.00145 .00

$10.00 \quad 80.00$

$12.00 \quad 112.00$

$\begin{array}{rr}7.00 & 60.00 \\ 11.00 & 95.00\end{array}$
12 to 18 in. X..........

The variety par excel-

2 or 3 yr. S......... \$ 1.00

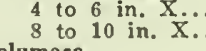

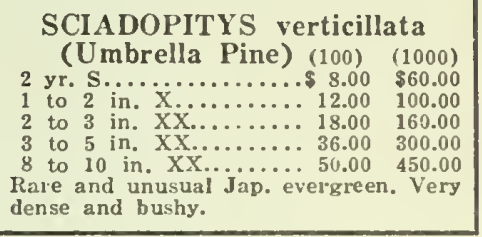

TAXUS (Yew)

Canadensis (Canadian $\mathrm{Ycw}$ )

7 to 9 in. X........... 20.0

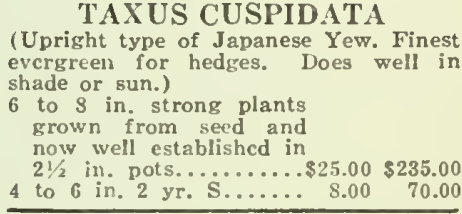

TAXUS CUSPIDATA

(Spreading Jap Yew)

6 to 8 in. onc year rooted

TAXUS CUSP BREYIFOLIA

(nana) (Dwarf Jap. Yew)

p

cuspidata aurea (Golden)

nuedia Hicksi

pots $\ldots$.......................

30.00

6 to 8 in. X........ $12.00 \quad 112.00$

baccata rependens (iveeping varicty)

6 to 8 in. R.C....... $18.00 \quad 160.00$

8 to $10 \mathrm{in.} X$

24.0022 .00

Washingto

$\begin{array}{ll}18.00 & 160.00 \\ 24.00 & 224.00\end{array}$

4 to 6 in. $X$

24.00
28.00

THUJA (Arborvitae)

occidentalis (White Cedar)

3
3
3 to 6 in. $\mathrm{X}$.

4 to 8 in.

pyramidalis
Rooted cu

10 to

BEST ARBOIRITAE HEDGE

Orc. globosa
(Woodwardi)

4 to 6 in.

$10.00 \quad 80.00$

cc. lutea (Geo. Peabody A rborvitae)

16.00145 .00

4 to 6
6 to 8

(Dougl

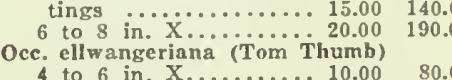

$\begin{array}{rr}12.00 & 112.00\end{array}$

Biota orientalis (Öriental A rborvitae)
HEMLOCK

(Tsuga canadensis)

A splendid native tree, excellent as a

specimcn or for a bedge. Will thrive

exposure.

ing-out Sizes

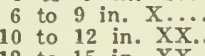

$4.00 \$ 20.00$

T. Carolina (Carolina Hemlock 


\section{Deciduous Tree Seedlings and Transplants}

ACER dasycarpum (Silver Maple) $\begin{array}{rr}(100) & (1000) \\ 2.50 & 20.00 \\ 7.50 & 60.00\end{array}$ 3 to $4 \mathrm{ft}$. X Branched.. 7.
Smaller grades on request.

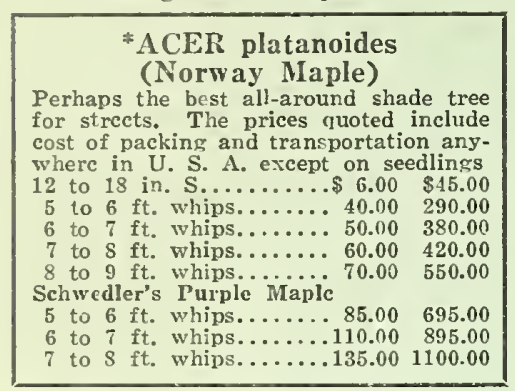

ACER rubrum (Red Maple)

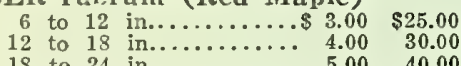

ACER saccharum (Sugar Maple)

$\begin{array}{rrrrr}6 & \text { to } 12 & \text { in.............. } & 2.50 & 20.00 \\ 12 & \text { to } 18 \text { in.............. } & 4.00 & 30.00 \\ 18 & \text { to } & \end{array}$

WEIR'S CUTLEAF MAPLE

3 to 4 ft. Whips....... $32.00 \quad 250.00$

AILANTHUS glandulosa

(Tree-c-Heaven)

18 to 24 in............. $3.00 \quad 25.00$

AESCULUS (Flowering

Horsechestnut)

hippocastanum

AESCULUS negiecta georgiana (Dwarf Red-Flowering Buckeye) Very rare shrub with red to ycllow

6 to 12 in............. \$ $5.00 \$ 40.00$

AESCULUS octandra

(Yellow Buckeye)

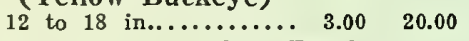

BETULA alba (White Birch)

12 to 18 in............. $12.00 \quad 90.00$

BETULA populifolia (Gray Birch)

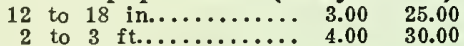

BETULA papyrifera

(Paper Birch)

$\begin{array}{rlrr}8 & \text { to } 12 \text { in................. } & 4.00 & 30.00 \\ 12 & \text { to } 18 \text { in........... } & 6.00 & 40.00\end{array}$

BETULA lenta (Sweet Birch)

12 to 18 in............. $2.00 \quad 15.00$

BETULA lutea (Yellow Birch)

$\begin{array}{rrrr}8 & \text { to } 12 \text { in................. } & 3.50 & 25.00 \\ 12 & \text { to } 18 \text { in........... } & 46.00 & 36.00\end{array}$

BETULA nigra (River Birch)

12 to 18 in............. $2.00 \quad 15.00$

CATALPA speciosa

(Western Catalpa)

18 to 24 in.............

$2.00 \quad 15.00$

CARPINUS Americana (Hormbeam)

6 to 12 in.......
12 to 18 in....
18 to 24 in...

$2.50 \quad 15.00$

ASTANEA dentata

(American Chestnut)

ERCIS canadensis (Red Bud)

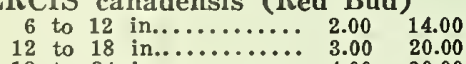

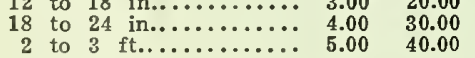

*CORNUS FLORIDA

(Flowering Dogwood)

$\begin{array}{rrr}2 & \text { to } 18 \text { in............ } 5.00 & 40.00 \\ 8 & \text { to } 24 \text { in. } \mathrm{X} . . . . .60 & 130.00\end{array}$

FAGUS ferruginea

(American Beech)

$\begin{array}{rl}6 & \text { to } 12 \\ 12 & \text { in... } \\ 18 & 18 \text { in... } \\ 18 \text { to } 24 \text { in.. }\end{array}$

AGUS sylvatica

(European Beech)

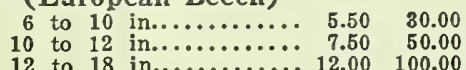

FRAXINUS (American

White Ash)

(100) $(1000)$

3 to 4 ft. X..........
12 to 18 in. S.......... $2.00 \quad 45.00$
10.00

GINGKO BILOBA (Maidenhair)

6 to 9 in............. $7.00 \quad 50.00$

GLEDITSCHIA (Honey Locust)

$\begin{array}{rrrrr}6 & \text { to } 12 & \text { in.............. } & 1.50 & \mathbf{9 . 0 0} \\ 12 & \text { to } 18 \text { in.............. } & 2.20 & 12.00 \\ 18 & \text { to } 24 & \text { in............. } & 3.00 & 20.00\end{array}$

HICORIA alba (Shellbark

Hickory)

6 to 12 in $\ldots .7 .00 \quad 60.00$

HICORIA ovata (Shagbark

Hickory)

6 to 12 in........... $7.00 \quad 60.00$

JUGLANS nigra (Black Walnut)

$\begin{array}{rrrr}6 & \text { to } 12 \text { in............... } \\ 12 & \text { to } 18 \text { in............. } & 4.50 & 22.50 \\ 30.00\end{array}$

JUGLANS cinera (Butternut)

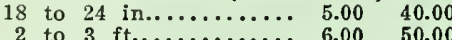

KOELREUTERIA paniculata

(Golden Rain or Varnish Tree)

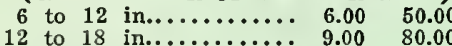

LIQUIDAMBER styraciflua

(Sweet Gum)

$\begin{array}{rrrrr}12 & \text { to } 18 & \text { in................. } & 4.00 & 30.00 \\ 18 & \text { to } 24 & \text { in.............. } & 6.00 & 40.00\end{array}$

LIRIODENDRON tulipifera

(Tulip Tree)

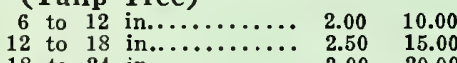

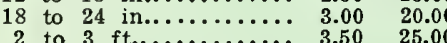

MAGNOLIA acuminata

(Cucumber Tree)

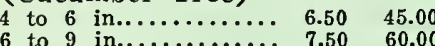

MALUS

SPECIAL OFFER

FLOWERING CRABS

Atrosanguinea. Brilliant carmine-red.

A rnoldiana. Large deep rose.
Sargent's. Dwarf white. 2 to $3 \mathrm{ft}$.,

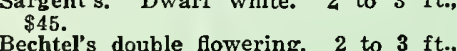

Floribunda. Single pink, early spread-

Spectabilis. Large rose-red.

Coronaria. Wild Sweet Crab. Very

Sheideckeri. Small deep pink.

All 2 and 3 year old plants.

Prices on all above except where noted.

MORUS alba (Russian Mulberry)

Attractive to birds.

A m ong others, the

Loon, Thrush, Tanager,

$\begin{array}{lll}\text { etc. } & (100) & (1000)\end{array}$

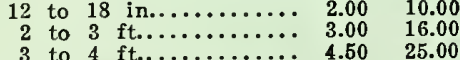

Other sizes on request.

NYSSA sylvatica (Tupelo or Sour Gum)

2 to $3 \mathrm{ft}$............. $6.00 \quad 50.00$

OXYDENDRON arboreum (Sorrell or Sourwood Tree)

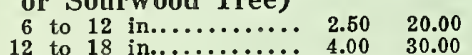

18 to 18 in.............. $4.00 \quad 3.00 \quad 40.00$

OSAGE orange

$\begin{array}{rrrrr}12 & \text { to } 18 \text { in.............. } & 1.50 & 7.50 \\ 18 & \text { to } 24 & \text { in.............. } & 2.00 & 12.00\end{array}$

PLATANUS occidentalis

(Sycamore)

12 to 18 in.............. $2.50 \quad 20.00$

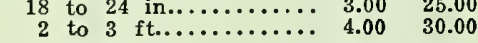

*PLATANUS orientalis

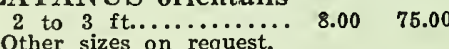

$\begin{array}{lll}2.50 & 10.00 & \text { POPULUS (Poplar) } \\ 3.00 & 15.00 & \end{array}$

Lombardy and Simon's Poplars 18 to 24 in. Whips.......2.00 $2.00 \quad 14.00$ Carolina and Norway Poplars \begin{tabular}{c}
2 to $3 \mathrm{ft}$. Whips....... $5.00 \quad 30.00$ \\
\hline
\end{tabular} Larger and small
QUERCUS alba (White Oak)

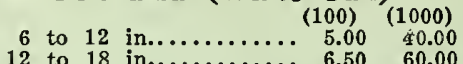
QUERCUS coccinea (Scarlet Oak) 6 to 9 in............. 4.50 40.00 *QUERCUS palustris (Pin Oak)

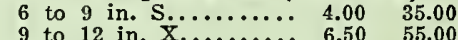

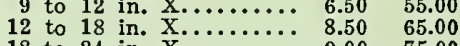

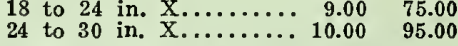

*QUERCUS rubra (Red Oak)

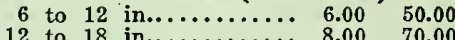
QUERCUS macracarpa

(Burr Oak)

QUERCUS Robur (English Oak)

ROBINIA (Black Locust)

$\begin{array}{llll}12 & \text { to } 18 \text { in............. } & 2.00 & 12.50\end{array}$ other sizes on request.

ALIX babylonica

(Weeping Willow)

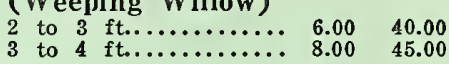

SORBUS aucuparia

(European Mt. Ash) (100) (1000)

TILIA americana

(A merican Linden)

$\begin{array}{rrrr}9 & \text { to } 12 \text { in............. } & 6.00 & 40.00 \\ 12 & \text { to } 18 \text { in. } \\ \end{array}$

ULMUS americana

(American Elm)

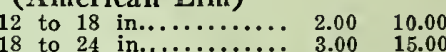

$\begin{array}{rlll}18 & \text { to } 24 \mathrm{in} \ldots \ldots \ldots \ldots \ldots . . & 3.00 & 15.00 \\ 3 \text { to } 4 \text { ft................ } & 4.00 & 30.00\end{array}$

ULMUS glabra (Scotch EIm) 12 to 15 in............ 12.00 110.00 ULMUS moline (Moline EIm) 2 to $3 \mathrm{ft.............25.00} 225.00$

ULMUS pumila (Chinese or Siberian Elm)

12 to 18 in............ $5.00 \quad 32.00$ 18 to 24 in...............
2 to 3 ft.............. 3 to 4 ft. whips......... $12.00 \quad 90.00$ 4 to 5 ft. whips....... $16.00 \quad 120.00$ 5 to 6 ft. X branched. $50.00 \quad 400.00$

\section{Evergreen Shrubs}

\section{AZALEA}

Amoena

4 to 6 in. X........... $30.00 \quad 225.00$

(New) Amoena coccinea (Fiery Rcd)
in. pots........... $30.00 \quad 280.00$

Benigiri

2 in. pots............ $16.00 \quad 120.00$

Calendulacea

Hinamayo

C. Trans. . . . . .... $14.00 \quad 120.00$

Hinodigiri

in. pots........... 14.00 140.00

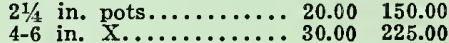

J. van Tol.

4 to 6 in. X......... $24.00 \quad 200.00$

Japonica

4 to 6 in. $X \ldots \ldots \ldots \ldots 15.00 \quad 120.00$

Kaempferi

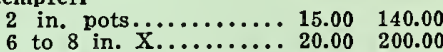

(New) Kaempferi Hybrids (Evergreen)

Alice-Large brilliant orange-red

Betty-Brilliant crimson-pink

Fedora-Deep salmon rose

Kathleen-Deep rose-pink

Willy-Pure clear soft-pink
$21 / 4$ in. pots............ $30.00 \quad 280.00$

Kurume-mixed varieties

2 in. pots............. $12.00 \quad 100.00$

Kurume-named varieties

Pink Pearl, Salmon Beauty. Snow

(New) Kurume-Sweet Briar

${ }_{21 / 4}^{1 / 4}$ in. pots.......... $30.00 \quad 280.00$

Ledifolia alba

2 in. pots. $\ldots \ldots \ldots \ldots \ldots \ldots 14.00 \quad 120.00$

Macranthus

Macranthu C. T

Maxwelli

$\begin{array}{lll}14.00 & 120.00\end{array}$

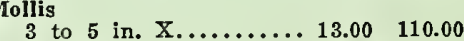
6 to 8 in. $X$

Mucronulata
6 to 8 in

6 to 8

2 to $18 \mathrm{in}$.

3 to 5 in $x$

Poukhanensis

4 to 6 in. $X$

$\mathrm{x} . .$.

3 to 6 in.
Schlippenbachi

chlippenbachi

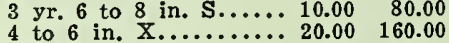

viscosa
12 to 18 in. S.......... $14.00 \quad 120.00$

$\begin{array}{llll}12 \text { to } 18 \text { in. S......... } 14.00 & 120.00 \\ \text { Yayegiri } & \\ \text { R. C. Trans........... } 14.00 & 120.00\end{array}$

$\begin{array}{llll}\text { Yodogawa } & \\ \text { R. C. Trans............. } 14.00 & 120.00\end{array}$

BELIA grandifiora $\begin{array}{rr}6-12 \text { in. } X \ldots \ldots \ldots \ldots \ldots . & 10.00 \\ 12-15 & 80.00 \\ & \end{array}$
Flame, Ledifolia Magnifica,

BUXUS (Boxwood) (100) (1000)

B. suffruticosa (Box edging)
3 to 4 in. $X$............. $8.00 \quad 75.00$ 4 to 6 in. X............. $10.00 \quad 88.00$ 6 to 8 in. $X \ldots \ldots \ldots \ldots \ldots 20.00 \quad 160.00$

B. sempervirens (True Bush Box)
4 to 6 in. X.......... $8.00 \quad 65.00$

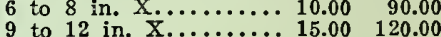

\section{COTONEASTER}

6 to 8 in. X......... $12.00 \quad 100.00$ APHNE

D. cncorum (Garland Flower)
Well rooted layers......24.00 24.05.00

GALAX

G. Aphylla

ILEX (Holly)

opaca (Amer. Holly) Nursery Grown

To succeed with Holly,

moved before planting.

6 to 8 in. S 2 yr........ $12.00 \quad 100.00$ 8 to 12 in. S 2 yr....... $18.00 \quad 150.00$

renata (Jap. Holly)

4 to 6 in. S.......... $5.00 \quad 35.00$ 8 to 10 in. $\mathrm{S} \ldots \ldots \ldots \ldots, \ldots, 7.00 \quad 60.00$ labra (Inkberry)

10 to 15 in. $S \ldots \ldots \ldots \ldots \quad 7.00 \quad 55.00$

KALMIA

atifolia (Laurel)

EUCOTHOE

cataeshaci
6 to 12

MAHONIA

aquifolium (Oregon Holly)

4 to 6 in. S.......... $5.00 \quad 45.00$

MAGNOLIA glauca

12 to 15 in. S. Nursery $20.00 \quad 160.00$ Other sizes on request.

PACHYSANDRA Terminalis

2 yr. plants........... $9.00 \quad 85.00$ PYRACANTHA Lelandi (Leland's Evergreen Fire Thorn)

$21 / 4$ in. pots........ $20.00 \quad 180.00$

RHODODENDRON

9 to 12 in. $S \ldots \ldots \ldots .8 .00 \quad 55.00$ 9 to 12 in. with ball... 20.0

3 to 6 in. S............. $9.00 \quad 60.00$ $\begin{array}{ll}3 & \text { to } 12 \text { in. S............. } 12.50 \quad 100.00\end{array}$ ybrids

VINCA minor (Myrtle)

Strong clumps ......... $6.00 \quad 50.00$
YUCCA filamentosa

3 yr. strong S........ 8.00 


\section{Deciduous Flowering Shrubs}

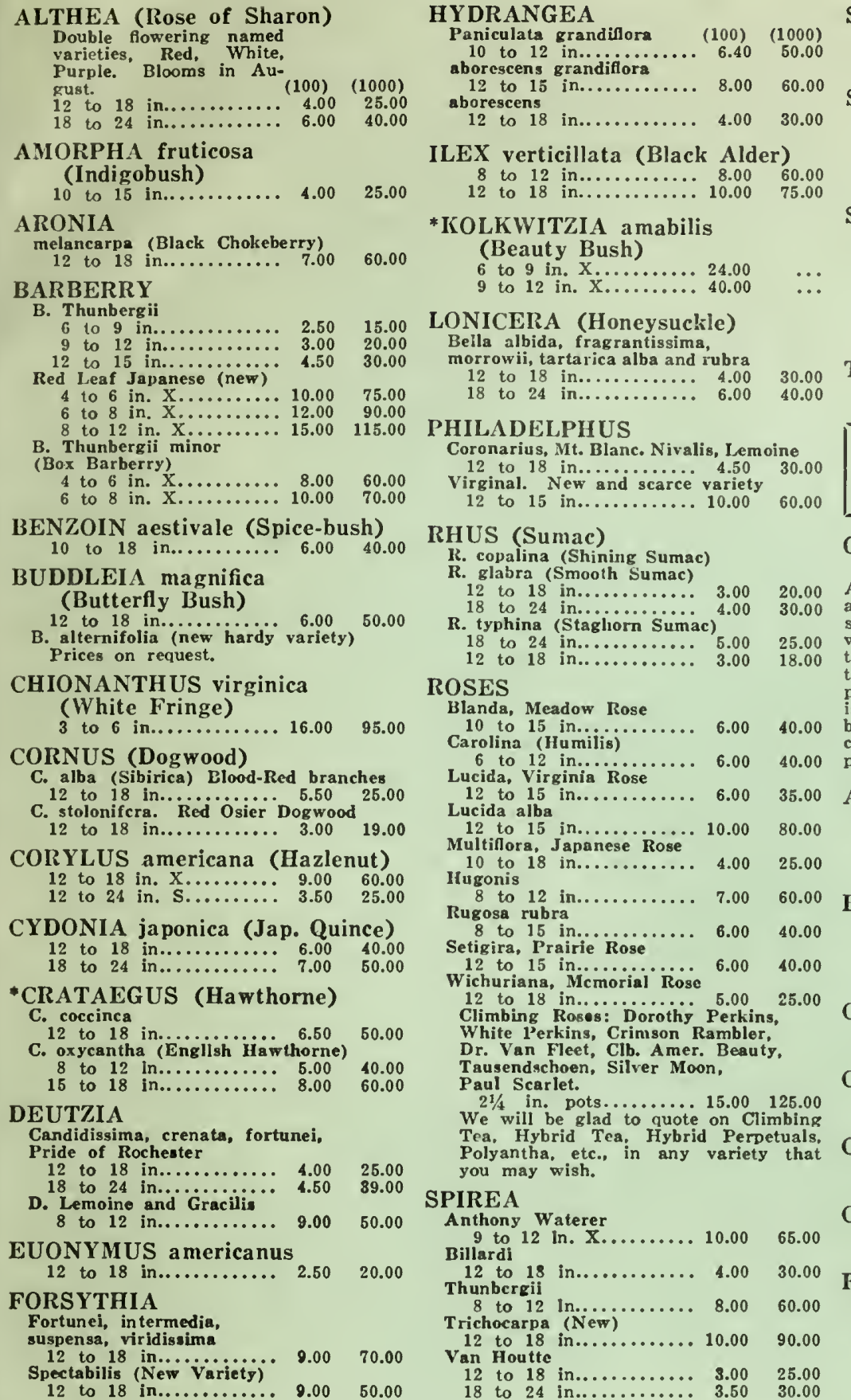

\section{STEPHANANDRA (Lace Bush) VIBURNUM}

S. flexuosa (100) (1000) Americanum. Amer, High Bush

10 to 12 in. X......... $10.00 \quad 70.00 \quad$ Cranberry $\quad(100)$ (1000)

\section{SYMPHORICARPUS}

Racemosus (Snowberry)

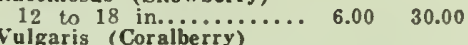

12 to 18 in............. $3.50 \quad 25.00$

SYRINGA (Lilac)

vuigaris, Common purple lilac

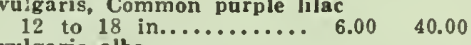

vulgaris alba

Pers.to 18 in............ 7.00

12 to 18 inurple)

$9.00 \quad 40.00$

TAMARIX africana

15 to 24 in........... $8.00 \quad 40.00$

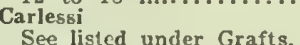

See listed under Grafts.
Dentatum (Arrow Wood

$6.00 \quad 50.00$

8 to 15 in................ $12.00 \quad 80.00$

Lantana (Wayfaring Tree) $9.00 \quad 70.00$

Opulus sterilis (Common Snowball)

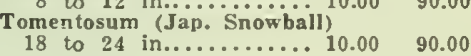
18 to 24 in

WEIGELIA

Rosea

12
Eva
Rathke (best red variety)

$6.00 \quad 30.00$ $14.00 \quad 100.00$

\section{Grafted Stock That Will Grow}

GRAFTED STOCK THAT WILL JUNIPERUS-Junipers GROW

All the following grafted trees and shrubs and evergreens are hardy. They have spent a year out of doors so that the graft wound is absolutely healed. You can plant them without fear of results and without the precaution and trouble incident upon planting frcshly made grafts. Everything is wcll-rooted and shipped with a small
ball and burlap. (Fresh grafts, if desired, an be furnished at materially lower priccs.)

\section{ACER-Maples}

Japanese Blood-leaf Maple (10) (100) 1 yr., 10 to 15 in. B\&B. $10.00 \quad 90.00$

1 yr., 10 to 15 in. B\&B. $12.50 \quad 95.00$

BIOT A-Oriental Arborvitae

B. aurea nana (Golden Dwarf)
1 yr., 8 to 10 in. B\&B. $9.00 \quad 70.00$

B. aurea conspicua (Golden Pyramidal)

$1 \mathrm{yr}$., 10 to 12 in. B\&B. 9.0070 .00

\section{CEDRUS-Cedar}

C. atlantica glauca (Blue Atlas Cedar)

CORNUS-Dogwood

C. florida rubra (Red Flowering)
1 yr., 12 to 18 in. B\&B. $9.00 \quad 75.00$

\section{CRYPTOMERIA}

C. japonica lobbi (Lobb Cryptomeria)
1 yr., 10 to 12 in. B\&B. 10.0090 .00

CUPRESSUS-Cypress

C. Triumph de Boskoop
1 yr., 12 to 18 in. B B B. $7.00 \quad 60.00$

\section{FAGUS-BEECH}

River's Purple Bcech. (F. Syl. Riversii) 1 yr., 12 to 18 in. B\&B. 10.0090 .00 Wceping Beech (F. Syl. pendula.)

1 yr., 12 to 18 in. B\&B. $10.00 \quad 90.00$

Fern-leaf Beech (F. Syl. heterophylla)

J. elrgantissima Lee
J. virginiana glauca (Silver Redcedar)

J. virginiana Cannarti (Decp black

green, columnar)

vir. Schotti (fresh green, compact

columnar)

J. chinensis columnari

$1 \mathrm{yr} ., 10$ to 15 in. B\&B. $\quad(10) \quad(100)$

MAGNOLIA

M. Soulangeana

$1 \mathrm{yr} ., 10$ to 12 in. B\&B. 12.50120 .00

18 to 24 in. B\&B...... $30.00 \quad 250.00$

M. Soulangeana nigra

A1. Stellata 15 in. B\&B. $12.50 \quad 120.00$

$\begin{array}{lll}1 \mathrm{yr} ., 10 & \text { to } 12 \text { in. B\&B. } 12.50 & 120.00 \\ 18 \text { to } 24 \text { in. B\&B...... } 40.00 & 360.00\end{array}$

. 18 in. B\&B..... $30.00 \quad 250.00$

PICEA-Spruce

P. Kosteri (Koster's Blue Spruce)

$2 \mathrm{yr} .8$ to 10 in. B\&B.. 13.50120 .00

4 yr. 18 to 24 in. B\&B. $50.00 \quad 450.00$

. Moerhcimii (Moerheim's Blue Spruce)

$1 \mathrm{y} r ., 7$ to 10 in. B\&B.. $13.50 \quad 120.00$ P. excelsa nidiformis (Dwarf

Pyramidal Spruce)

$1 \mathrm{yr} ., 6$ to $8 \mathrm{in}$. B\&B... 13.50120 .00

PINUS tanyosho (Jap. Table Pine)

1 yr., 8 to 12 in. B\&B.... 15.00130 .00

TSUGA-Hemlock

T. canadensis Sargenti

(Sargent's Weeping Hemlock)

1 y 12 to 15 in. B\&B, $12.50 \quad 105.00$

VIBURNUM

V. Carlesii (May-flowered Viburnum)

1 yr.. 8 to 12 in. B\&B.. $10.00 \quad 90.00$

1 yr., 12 to 15 in. B\&B. $9.00 \quad 75.00$

\section{REFORESTATION}

$W^{\mathrm{E}}$ are prepared to quote and furnish seedlings by the million and transplants by the hundreds of thousands at prices as low or lower than offered by other forestry nurseries offering this class of material. Varieties include all the favored Pines and Spruces for this purpose, as well as many unusual kinds at exceptionally low prices. Write us for special quotations.

A few years ago we furnished on a New Jersey State contract some half million transplants at a saving of many thousands of dollars over the next lowest bidder. Not one percent of the planting failed. For the past three years we have been furnishing up to 400,000 a year on a watershed planting in Pennsylvania in open competition year by year-both price and quality considered. Stock is northern grown and strong and well rooted-carefully raised from selected strains of seed. We solicit inquiries both large and small. 


\section{Handling Small Evergreens}

The joy of watching baby trees grow up is a lasting one. In its earlier stages an evergreen requires some attention, but nothing which cannot be readily learned and practiced by an amateur. The following notes are designed to acquaint the beginner with the fundamental facts. For prices on small sizes refer to inside pages. For more detailed information, see the back cover for technical books, or write us for advice.

\section{Seedlings ("S")}

Many varieties of evergreens are raised from seed until they are two or three years old. These very small plants must be handled with extra care. They should be planted about four inches apart in beds. The beds can be four feet wide and as long as is necessary-up to 100 or 150 feet. Here they are left two years and for the first year, during the heat of the first Summer, should be shaded by a lath screen, rested on posts driven into the ground. They are hand cultivated frequently if satisfactory growth is to be obtained. In the Autumn, mulch with dead leaves three inches deep to prevent frost-heaving. At the end of two years, they should be talken from the beds and treated as transplants.

\section{Transplants ("X")}

Evergreens that have been moved from one position to another, or that have had their roots pruned, tend to throw out extra roots near the stem, forming a close compact ball of fibrous roots that can be easily dug up when the tree is ready for its permanent location. This thick root system increases the chances for success enormously.

Transplants under six irches are so small that they can best be handled in the same way as seedlings, except in reforestation plantings. But over six inches in height the transplant is sufficiently sturdy to be planted out in the open field in rows four feet apart, and a foot or more apart in the rows, depending on the size of the transplants. Here the roots have room to grow, and the tops have room for shapely development. They should be cultivated to encourage a good growth, and being planted in rows, a power cultivator can be used.

\section{Forestry}

Transplants and even seedling of the hardier types Spruce, Pine, Fir, etc.-can be set out immediately in their permanent positions where a large acreage is to be forested or where a screen or mass effect is desired. A space one foot square should be cleared and the tree planted carefully and firmly. Such a planting requires no further care except for occasional clearing away of weeds. However, when first planted each tree must be thoroughly watered and for the next month should be further watered if rain is not normally plentiful.

\section{Watering}

Note well: an evergreen dies if its roots dry out. Whenever a shipment of evergreens is received, the roots should be examined and immediately soaked if they prove at all dry. They should then be planted at once if possible and well watered after planting and still once more two or three days later.

\section{Heeling In}

If it is impossible to plant evergreens immediately, they should be "heled in." Dig a trench in a shady spot deep enough to hold the roots and open all bundles and spread the roots naturally in the trench. The earth is carefully thrown in over the roots and tramped down, water heavily. Evergreens may safely remain here two or three weeks until it is convenient to plant out.

\section{Rooted Cuttings ("R.C.")}

Many evergreens do not come true to type from seed. These are propagated by cuttings of branches rooted in sand. It is a diffcult process, requiring months in a greenhouse under exact barometric conditions. In the case of the Yews, often two years is required. For this reason, cuttings are much more expensive than seedlings. They require the same care (for the first year) as seedlings, but once they have passed a Winter in the beds they can be treated as transplants, except for a few special varieties.

\section{Grafts}

Some trees which do not come true from seed will not even take root readily. These varieties are grafted on established roots of related species and when the graft is healed are perfectly hardy and can be treated as transplants. But during the first year, while the graft is healing, they must be carefully tended. Plant in beds and provide lath shading, removing on dull days so that the ground is not too wet. Mulch carefully in Winter and if possible place a wind protection around each bed. Once a Winter is safely passed out-of-doors, the danger is over. For this reason it is best to buy grafted varieties one year old. A few of these are listed on page 20 .

\section{How Many Trees in a Bed?}

In a bed 4 feet wide and 10 feet long the following table indicates the number of trees. In a four-inches-apart planting and a bed 100 feet long, for instance, there would be 3,600 trees.

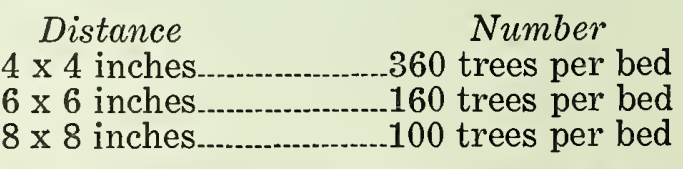

How Many Trees per Acre?

Rows 3 feet apart, trees 1 foot apart 14,520

Rows 3 feet apart, trees 2 feet apart 7,260

Rows 4 feet apart, trees 2 feet apart 5,450

Rows 5 feet apart each way...-...-...- 1,745

Rows 6 feet apart each way......-......-. 1,210 


\section{TREES AND SHRUBS THAT ATTRACT BIRDS}

The following list of hardy fruit-bearing shrubs for food for birds will be found convenient for ready reference. It embraces the best varieties that can now be furnished in quantity. The numbers following the bird names refer to the numbered plants as below. Prices are listed in the green folder.

Game Birds

Grouse: 2-5-6-7-8-11-12-16-20-

$$
\text { 21-22-26. }
$$

Partridge: 6-7-11-12-26.

Pheasant: 11-12-21-26.

Prairie Chicken: 8-20.

Quail: 2-5-6-7-11-12-15-17-19-22.

Snipe: 2-6-7-12-26.

Wild Geese: 13-24.

Woodcock: 6-7-26.

Song and Plumage Birds

Blackbird: 5-6-7-15-19-22.

Bluebird: 4-5-6-7-8-11-12-15-1719-21-22-21-26-27.

Bobolink: 15-17-21-27.

Cardinal: 4-6-7-15-21-27.

Chickadee: 6-7-19-21.

Cuckoo: 15-21-27.

Finch: 6-7-21.

Flicker: 4-6-7-11-12-16-17-19-2122-27.

Kingbird: 2-6-7-15-17-18-19-2122-26-27.

Lark: 1-2-5-6-7-15-17-21-26-27.

Meadowlark: 1-26-27.

Mockingbird: 3-1-11-12-15-1718-19-21-22-27.

Oriole: 15-17-21-22.

Starling: 6-7-13-15-16-17-19-2122-26-27.

Swallow: 6-7-19.

Tanager: 15-17.

Thrush: 6-7-11-12-15-17-18-1921-26.

Waxwing: 4-6-7-8-11-12-13-1517-21-2.4-26.

Warbler: 13-19-21-26.

Woodpecker: 6-7-11-12-15-1719-21-22-26-27.

Wren: 2-9-19-21-22
Trees and Shrubs

I Aronia arbutifolia

2 Berberıs Thunbergi

3 Callicarpia (French Mulberry)

4 Celtis (Hackberry)

5 Cephalanthus (Button Bush)

6 Cornus Stolonifera

7 Cornus Florida

8 Eleagnus (Silverberry)

9 Euonymus Americana

10 Gaylussacia (Huckleberry)

11 Ilex Opaca (Holly)

12 Ilex Verticillata

13 Juniperus Virginiana (Red Cedar)

14 Lonicera (Honeysuckle) (bush) (vine)

15 Morus (Mulberry)

16 Nyssa Multiflora

17 Prunus (Choke Cherry)

18 Rhamnus Cathartica (Buckthorn)

19 Rhus (Sumac) (in variety)

20 Rosa (Rose) Lucida and Nitida

21 Rubus (Raspberry)

22 Sambucus (Elderberry)

23 Sassafras Officinale

21 Thuya American (Arborvitae)

25 Symphoricarpos Vulgaris (Snowberry)

26 Viburnum prunifolium

27 Vitis (Wild Grape)

\section{HERE ARE THE FIVE BEST}

Japanese Barberry

12 to 15 inches.

Flowering Dogwood

12 to 18 inches.

American Highbush Cranberry

12 to 18 inches.

Spicebush (Benzoin)

10 to 18 inches.

Russian Mulberry

2 to 3 feet
(100)

$\$ 4.50$

5.00

10.00

40.00

90.00

6.00

40.00

3.00

16.00

\section{BIRD-FOOD OFFER No. 1}

Ten each of the above five kinds-50 nursery-grown seedlings, 12 to 18 inches high, packed and shipped, postpaid for.

$\$ 8.00$

\section{BIRD-FOOD OFFER No. 2}

Three each of the above five kinds -15 transplanted shrubs and trees, 2 to 3 feet high, packed and shipped, postpaid, for . ........... 


\section{WE RECOMMEND THESE BOOKS}

We consider the following books to best cover their respective subjects. Prices quoted include postage. We will gladly execute your orders direct, at publisher's prices:

\section{STANDARDIZED PLANT NAMES}

By American Joint Committee on Horticultural Nomenclature. An index of 45,000 plant names giving the scientific and common names approved by authorities. Does not give pronunciation or culture. 548 pages, $51 / 4 \times 8,1923$. Cloth, $\$ 6.00$, postpaid.

\section{AMERICAN PLANTS FOR AMERICAN GARDENS}

By Roberts and Rehman. Association of plants and trees as Nature does it. 131 pages, 11 illustrations. Cloth, \$2.15.

\section{THE BOOK OF SHRUBS}

By Alfred C. Hottes. Gives comparison of species, characteristics, uses, soil, pruning, propagation, height in feet, exposure to plant, color of flowers, season of bloom, color of fruit, etc. Gives list of different shrubs for different purposes. 371 pages, $7 \times 71 / 2$, 124 halftones, 56 sketches, 44 tables. 1928. Cloth, $\$ 3.15$.

\section{GARDEN GUIDE}

Each subject written by an authority. Edited by A. T. De La Mare. Exceptionally complete and reliable. Nearly 400 pages with over 275 illustrations. Paper, $\$ 1.10$, Cloth, $\$ 1.65$.

BIRDS OF THE WILD ("How to Make Your Home Their Home")

By Frank C. Pellett. Tells what plants to plant to attract wild birds as well as giving habits and descriptions of the wild birds. An original subject treated by a man of 20 yearsexperience. 128 pages, $5 \times 7 \frac{1}{2}, 74$ halftones. 1928. Cloth, $\$ 1.85$, postpaid.

\section{FOUNDATION PLANTING}

By Leonard H. Johnson. Shows how to beautify the immediate frontage of the house by means of plants. 236 pages, $71 / 2 \times 10$ with 208 halftones and planting plans of mostly frontages with a few sides and rears. 1927 . Cloth, $\$ 3.65$.

\section{FIRST COUNTY PARK SYSTEM}

By Fred'k W. Kelsey. A history of the development of the parks of Essex County, N. J. 300 pages, illustrated. Cloth, $\$ 2.00$.

\section{EVERGREEN HEDGES}

A small leaflet, Kelsey Nursery Service. Free.

\section{HOW TO PLANT}

Sixteen page booklet, Kelsey Nursery Service. Free.

\section{CULTIVATED EVERGREENS}

By L. H. Bailey. Recognized as the best handbook on the woody evergreens. 434 pages; 163 illustrations. $\$ 3.15$.

\section{STANDARD CYCLOPEDIA OF HORTICULTURE}

By L. H. Bailey. The one universal and invaluable authority. Makes a compact but thorough presentation of the kinds, characteristics and methods of cultivation of plants. 3,637 pages; 5,000 illustrations, three vol. $\$ 25.00$.

\section{HORTUS}

By L. H. Bailey. A cyclopedia in brief for those not possessing the above. A complete dictionary of American Horticulture. 652 pages. $\$ 10.15$.

\section{THE NURSERY MANUAL}

By L. H. Bailey. An extended list of plants with propagation methods. 453 pages; 240 illustrations. $\$ 2.60$.

\section{THE PRUNING MANUAL}

By L. H. Bailey. Instructions on just how and when to prune trees, shrubs, and vines. 4.00 pages; 381 illustrations, $\$ 2.60$.

\section{MANUAL OF CULTIVATED TREES AND SHRUBS}

By Alfred Rehder. The most complete reference available on trees and shrubs. The "Supreme Court" for decisions about plants. 967 pages. $\$ 10.50$.

\section{CONSTRUCTIVE FORESTRY FOR THE PRIVATE OWNER}

By J. J. Crumley. A guide to profitable management for the private timber owner. 340 pages; 80 illustrations. $\$ 3.65$.

\section{MANUAL OF TREE AND SHRUB INSECTS}

By E. P. Felt. Identification and control of insects attacking shade and forest trees, shrubs, and ornamentals. 398 pages; 256 illustrations. $\$ 3.65$.

\section{KELSEY NURSERY SERVICE}

